\title{
STRUMA EN CRETINISME IN DEN INDISCHEN ARCHIPEL.
}

\author{
DOOR
}

Dr. G. A. WILKEN.

Als eene kleine bijdrage tot de geographische pathologie, stel ik mij voor in de volgende bladzijden eenige mededeelingen te doen aangaande de verbreiding van struma en cretinisme in den Indischen Archipel. "Het is niet noodig", merkt Dr. Van der Burg, in zijn werk "De Geneesheer in Nederlandsch Indië", op, "deze ziekten, die geene afwijkingen vertoonen met de vormen, welke overal elders worden waargenomen, uitgebreid te bespreken; alleen moet op het tamelijk veelvuldig voorkomen daarvan in de berglanden van Java, Bali, Sumatra en Borneo worden gewezen " 1. Intusschen kan eene meer nauwkeurige opgave van de plaatsen op evengenoemde eilanden, waar struma en cretinisme endemisch heerschen, gewenscht zijn. Het is immers juist eene eigenaardigheid van deze beide kwalen, dat zij zoo bij uitstek aan bepaalde localiteiten gebonden zijn, eene eigenaardigheid die zij, om de woorden van Hirsch te gebruiken, "wenigstens in so prägnanter Weise, nur mit äusserst wenigen, anderen Krankheitsformen theilen, und welches sich in annähernd gleicher, oder ähnlicher Weise namentlich bei den Malariakrankheiten geltend macht ${ }^{2}{ }^{2}$. - Het eerst komt struma in aanmerking.

I.

Op Sumatra, om met dit eiland te beginnen, komt struma veelvuldig voor. "The natives of the hills, through the whole extent

1 Van der Burg, De Geneesheer in Nederlandseh Indië, dl. II, blz. 581.

2 Hirseh, Handbuch der historisch-geographisohen Pathologie, dl. I, blz. 421 (van den eersten druk). Waar verder, in dit opstel, dit werk geciteerd wordt, is, indien niets er bij vermeld wordt, de tweede druk (1883) bedoeld. 
of the island", zegt Marsden, "are subject to those monstrous wens from the throat, which have been observed of the Vallaisans, and the inhabitants of other mountainous districts in Europe.... The Sumatrans do not appear to attempt any remedy for it, the wens being consistent with the highest health in other respects". Meer bepaaldelijk heeft Marsden misschien Zuid-Sumatra op het oog gehad, want nergens is de kwaal zoo algemeen als hier. In de eerste plaats moeten de Redjang-landen genoemd worden. Deze bestaan, gelijk bekend is, uit de drie landschappen Redjang-Lebong, RedjangAmpat-Petoelai, ook Redjang-Tengah of Redjang-Moesi geheeten, en Redjang-Ampat-Jawang ${ }^{4}$. Van den Boekit-Seblat, in het Noorden van de Palembangsche Bovenlanden, loopt evenwijdig aan het Barisangebergte, dat zich langs de grenzen van Bengkoelen uitstrekt, eene andere keten. De breede vallei, die dus gevormd wordt en Zuidelijk door den tweelingvulkaan Boekit-Hitam en Goenoeng-Kaba wordt afgesloten, omvat de landschappen Redjang-Lebong en RedjangAmpat-Petoelai. Dit laatste doet zich voor als eene uitgestrekte vlakte, voor het grootste gedeelte met bosch bewassen ${ }^{5}$. Ten Zuiden van den Boekit-Hitam en Goenoeng-Kaba vormt de voortzetting van deze vallei een 300 tot 400 M. hoog plateau, dat zich tot den vulkaan Dempo uitstrekt, en waarvan het Zuidelijk gedeelte het landschap RedjangAmpat-Lawang uitmaakt, terwijl het Noorder deel tot RedjangAmpat-Petóelai behoort. Het is nu bepaaldelijk in Redjang-AmpatPetoelai en in Redjang-Ampat-Lawang, dat struma endemisch is. Zoo zag de Officier van Gezondheid Schuckink Kool vele lijders daaraan in het eerstgenoemde landschap ${ }^{6}$. Een overgroot aantal mannen en vrouwen, schrijft een ander berichtgever, de Majoor Van Rees, zijn behept

3 Marsden, History of Sumatra, blz. 48.

4 Het administratieve spraakgebruik heeft gewild, dat het eerste landschap thans alleen Lebong, het laatste alleen Ampat-Lawang genoemd wordt, zoodat voor den naam-van het middelste Redjang alleen kan volstaan.

' Ziehier hoe de leden van de Sumatra-expeditie, van Lebong komende, het landschap Redjang besohrijven: "Te half twee hadden wij het einde van de rimboe bereikt en verheugden onze oogen zioh in de aanschouwing van een verrukkelijk vergezicht. Geheel Redjang lag voor ons als eene uitgestrekte vlakte, rechts begrensd door de lage bergketen die het landschap van Bengkoelen afsoheidt, terwijl recht tegenover ons de uit den Goenoeng-Hitam en Goenoeng-Kaba samengestelde tweelingvulkaan zich hoog uit de vallei verhief. Zoowel de zacht glooiende hellingen van dien berg als het grootste gedeelte van de vlakte, die thans onzen blik boeide, zijn geheel met bosch bewassen" (Reizen in Midden-Sumatra door de leden der Sumatra-expeditie, dl. II, blz. 137).

${ }^{6}$ Geneeskundig Tijdschrift voor Nederlandsch Indië, dl. XXIV, blz. 160. 
met afzichtelijke kropgezwellen, die soms als een ring om den geheelen hals zitten of ook wel als een gevulde buidel naar beneden hangen. De aangetasten zijn niettemin even opgewekt en lustig als de gezonden ${ }^{7}$. Ook de Heer Pruys van der Hoeven zegt dat struma in Redjang "eene algemeene kwaal" is 3. Echter schijnen enkele streken eene uitzondering te maken. De Heer Van Rees vermeldt namelijk, dat de inlanders de kropgezwellen toeschrijven aan het drinken van water uit kleine stroomen of leidingen, die langs de ladangs of rijstvelden loopen. Zij toch, die aan de Moesi wonen, en uitsluitend van het zuivere rivierwater gebruik maken, blijven, naar men zegt, van de kwaal bevrijd ${ }^{9}$. Volgens den Heer Pruys van der Hoeven komt struma niet voor bij de bewoners van de dusuns of dorpen langs de Ajer-Poetih. Deze, een linkertak van de Moesi, ontspringt op den vulkaan Kaba en wordt gevoed door talrijke heete bronnen, die in hare bedding uitmonden. Aan de geneeskracht van het water van deze rivier schrijft de inlander de afwezigheid van struma toe ${ }^{\mathbf{1 0}}$. Niet minder veelvuldig doet struma zich in Redjang-Ampat-Lawang voor. In eene beschrijving van dit landschap, zegt de Officier van Gezondheid Buning, dat wel het zesde gedeelte der bevolking, zoowel mannen als vrouwen, door kropgezwellen ontsierd is, van af eene nauw merkbare zwelling aan den hals tot de meest monstrueuze massa's van verschillende gedaante. De gezwellen ontwikkelen zich eerst op lateren leeftijd, daar kinderen er van verschoond zijn 11 .

Zuidelijk van de Redjang-landen, wordt struma in Pasemah-Lebar gevonden. Dit landschap is een 500 tot $700 \mathrm{M}$. hoog plateau, dat zich van het Noordwesten naar het Zuidoosten, tusschen de vulkaantoppen Dempo en Patah, uitstrekt. De bodem mag eer vlak, dan geaccidenteerd worden geheeten, doch is afgebroken door, dikwij!s vele honderde voeten diepe, ravijnen, die de beddingen vormen van de talrijke, van den verbindingsrug tusschen de twee genoemde bergen afvloeiende, rivieren. In het Noorden en Noordoosten, waar het plateau open is, ontwaart het oog niets dan velden met alang-

7 Van Rees, De annexatie der Redjang, blz. 98.

8 Natuurkundig Tijdschrift voor Nederlandsch Indië, dl. XXIII, blz. 69.

9 Van Rees, t. a. p.

10 Natuurkundig Tijdschrift voor Nederlandsch Indië, dl. XXIII, blz. 69 en 218. Ook huidziekten, onder anderen de elders zoo gevreesde framboesiae, zijn in het gebied van de Ajer-Poetih, volgens den inlander om dezelfde reden, zeldzarm.

11 Buning, Topographische sohets der Ampat-Lawang, Geneeskundig Tijdschrift voor Nederlandsch Indië, dl. IX, blz, 627 en 630. 
alang-gras bewassen, die met hunne vaalbruine tint eene eentoonigheid aan het tooneel geven, welke alleen nu en dan verbroken wordt door de hooge bamboe-aanplantingen, waarachter de dusuns of dorpen verscholen liggen. Het hoogere gedeelte van het plateau, aan den kant van den verbindingsrug tusschen den Patah en den Dempo, biedt meer afwisseling in plantenvormen aan: de grond is boschrijker, terwijl men er meer sawah-velden ontmoet ${ }^{12}$. Het voorkomen van kropgezwellen in dịt gebied vinden wij geconstateerd door Presgrave, in het verhaal van eene door hem, op last van Raffles, in 1817 ondernomen reis naar de Palembangsche Bovenlanden. Van Manna, in Bengkoelen, vertrokken, was GoenoengAgoeng, aan den Zuidelijken voet van den Dempo, het eerste dorp in Pasemah-Lebar, dat Presgrave bereikte. "The people of this village", dus schrijft hij, "are particularly affected with goitres, some of which grow to an immense size, and render the patient a disgusting object. Among themselves they do not look upon these monstrous excrescences as deformities, nor do they seem to experience any pain or inconvenience from them. The inhabitants on the plains are entirely free from the disorder, while as you approach the hills almost every individual is affected with it" 13. Overigens is ons geen ander bericht over het voorkomen van struma in Pasemah onder de oogen gekomen. Alleen maakt Van Bloemen Waanders er terloops gewag van. In de beschrijving eener door hem op Bali gedane reis, zegt hij namelijk, dat hij op dit eiland, "evenals in de hooglanden van Sumatra, met name in de Pasemah-landen", vele mannen en vrouwen met ontzaggelijke kropgezwellen zag ${ }^{\mathbf{1 4}}$.

Onder de rivieren, welke op den verbindingsrug tusschen den Dempo en den Patah ontspringende, zich door het plateau van Pasemah-Lebar eene honderde voeten diepe bedding gegraven hebben, behoort ook de Lematang, die Noordoostelijk vloeiende, zich later rechts in de Moesi stort. Het land waardoor de rivier stroomt, nadat deze het plateau verlaten heeft, is bekend onder den naam

12 Gramberg, De inlijving van het landsohap Pasemah, blz. 10-11.

13 Presgrave, Account of a journey from Manna to Pasummah-Lebar and the ascent of Gunung-Dempo, Journal of the Indian Archipelago, New series, dl. II, blz. 10. Oorspronkelijk werd dit reisverhaal gepubliceerd in het tweede deel van de "Malayan Miscellanies", gedrukt te Bengkoelen. Een uittreksel daarvan komt ook voor in de "Memoir of the life and public services of Sir Thomas Stamford Raflles", dl. I, blz. 357 vlg.

14 Dagverhaal eener reis over Bali in Juni en Juli 1857, Tijdsohrift v. Nederl. Indië, jaarg. 1870 , dl. I, blz. 420 . 
van Lematang-Oeloe. Hier zoowel als in het aangrenzende SemendoDarat, het stroomgebied van de Enim, een rechtertak van de Lematang, komt struma endemisch voor. "Mijne meeste waarnemingen ", schrijft de Officier van Gezondheid Dr. Wyckerheld Bisdom, "zijn uit den bovenloop der Enim, welke rivier daar een ravijn vormt van 1500 voet diepte. De paden, die beide zijden van het ravijn verbinden, zijn zeer steil en voor Europeanen moeielijk te begaan. Ook de andere paden, die in het landschap worden aangetroffen, gaan alle door $\min$ of meer diepe ravijnen, zoodat de inwoners bijna nooit vlak terrein hebben. Sedert eenige jaren loopt echter een kunstig aangelegden rijweg, langs de bochten van het Enim-ravijn, zacht glooiend over eene lengte van vijftien palen. Langs dezen weg vindt men talrijke koffieaanplantingen, terwijl de bevolking zich overigens met den rijstbouw bezig houdt. De bewerkers der rijstvelden en der koffietuinen, welke meestal op heuvels liggen en door roofbouw ontgonnen worden, blijven daar veelal een jaar wonen, en drinken dan het water, dat uit den grond opborrelt: dit water nu wordt door de meeste lijders als oorzaak der struma beschouwd". "Mij kwam het voor", schrijft Dr. Wyckerheld Bisdom vérder, "dat over het algemeen meer vrouwen dan mannen aan de kwaal lijden". Overerving schijnt alleen in de vrouwelijke lijn plaats te hebben, gelijk een onderzoek naar de herediteit, in de weinige gevallen dat dit kon geschieden, eigenaardigerwijze aan het licht bracht. Overigens openbaart zich de ziekte op verschillende tijdstippen. Zoo ontstond "bij eene vrouw de zwelling bij hare eerste menstruatie, bij eene andere -kort na het huwelijk". Van de 89 door Dr. Wyckerheld Bisdom daarop onderzochte lijders bleek het, dat 12 de zitplaats van de struma uitsluitend rechts en 8 uitsluitend links hadden, terwijl bij de overigen het gezwel beiderzijds of wel in het midden zat. De consistentie was afwisselend, van week tot zeer hard; de vorm meestal gelapt, soms zelfs knollig, enkele malen glad omschreven. De grootte varieerde tusschen die van een grooten knikker en eene gewone papajavrucht 15. Bijna alle aangetasten gaven op, dat zij, bij wassende maan, meer van beklemdheid en kortademigheid te lijden hadden, ofschoon Dr. Wyckerheld Bisdom hiervan niets heeft kunnen waarnemen. Van het groote aantal vrouwen was er echter niet eene, die gedu-

15 De vruoht van de papaja (carica papaya) is ongeveer zoo groot als een meloen. 
rende de menses meerdere of mindere zwelling of benauwdheid had opgemerkt ${ }^{16}$.

Nog van twee andere landschappen in dit gedeelte van Sumatra, namelijk van Makakau en Belalau, vinden wij het endemisch voorkomen van struma bericht. Belalau is een gezond en vruchtbaar plateau, ten Zuiden van het meer Ranau gelegen, op eene hoogte van $900 \mathrm{M}$. boven de zee, terwijl Makakau het middelste gedeelte is van een ander plateau ten Noorden van evengenoemd meer, welk plateau in het Zuiden eeve hoogte heeft van $700 \mathrm{M}$, doch naar het Noorden en Noordoosten geleidelijk tot 250 M. daalt 17 . Op beide plateaux vindt men afwisselend velden en bosschen; doch deze laatsten zijn minder dicht, dat wil zeggen minder met ruigte en kreupel- of onderhout begroeid, dan de wouden, die men in de lagere landen aantreft. Rijk is ook het plateau, waartoe Makakau behoort, aan bamboe van de grootste soort, die aaneengeschakelde wildernissen vormt, ondanks de zichtbare verwoestingen, welke de olifanten daarin aavrichten $\mathbf{1} \mathbf{7}$ a. Ten aanzien van het voorkomen van struma in Belalau nu zegt Forbes, sprekende van zijn verblijf in het dorp Hoedjoeng. "Here and throughout the district goitre was extremely prevalent, nearly twenty per cent. of the people being affected. I saw even children of seven and eight years of age with the beginning of the disease" 1 3. Nog meer dan in Belalau, komt in Makakau de kwaal voor. "I was told", merkt Forbes op, "that in the Makakau district, which is notorious for its goitre, seventy per cent. are affected" 19. Nog in een ander bericht vinden wij het veelvuldig voorkomen van struma in Makakau, bepaaldelijk in het gebied van de Selaboeng, bevestigd. Deze rivier is eene uitwatering van het meer Ranau. Na eerst in Noordwestelijke richting over het plateau te zijn gestroomd, neemt zij links de Makakau op ${ }^{20}$, en verandert haren loop in eene Noordoostelijke richting, om, na te Moeara-Doea met de Saka te zijn samengekomen, den naam

16 Wyckerheld Bisdom, Een en ander bij struma, Geneeskundig Tijdschrift voor Nederlandsch Indië, dl. XXIX, blz. 524 vlg.

17 Verbeek, Topographische en geologische beschrijving van Zuid-Sumatra, Jaarboek van het Mijnwezen in Nederlandsch Oost-Indië, jaarg. 1881, dl. I, blz. 15 .

${ }_{17} a$ Tijdschrift voor Nederlandsch Indië, jaarg. 1857, dl. I, blz. 24, 25 en $32-33$.

18 Forbes, A naturalist's wanderings in the Eastern Archipelago, blz. 171.

19 Forbes, t. a. p.

20 Volgens sommigen krijgt de rivier, eerst na de vereeniging met de Makakau, den naam van Selaboeng, en heet zij vóór dien tijd Wala (Zie: Tijdschrift voor Nederlandsch Indië, jaarg. 1856, dl. II, blz. 358-359 en jaarg. 1873, dl. II, blz. 283). 
van Komering aan te nemen. Het is nu bepaaldelijk in het gebied, dat de Selaboeng doorstroomt na zich met de Makakau te hebben vereenigd, waar veel strumalijders worden gevonden. "Deze plaag", aldus lezen wij, "is bij eenigszins bejaarde personen, en voornamelijk bij de vrouwen, aan de Selaboeng bijkans algemeen, zoodat men van honderd menschen nauwelijks twintig ziet, die van deze afzichtelijke kwaal bevrijd zijn. Onder de jonge of rondzwervende mannen (hoedanig men daar veel aantreft, zooals overal elders in dit gedeelte van Sumatra en waarschijnlijk wel over het geheele eiland), wier levenswijs eene gedurige verandering van plaats ten gevolge heeft, vindt men weinigen, die daarvan aangetast zijn; maar gewoonlijk lijden hier de nuttige personen het meest, wier ordentelijke, bedaarde leefwijs zich tot humne rijstvelden bepaalt, alsook de gehuwde vrouwen, welke natuurlijk door hare huiselijke bezigheden aan hare woonplaats gebonden zijn". Ook bij de bewoners van de zooeven genoemde Sakarivier worden kropgezwellen aangetroffen ${ }^{21}$.

Het is echter niet alleen in de bergstreken, dat struma in ZuidSumatra endemisch heerscht. Ook in de lagere landen is dit het geval. Zoo in Rawas, dat zich Oostelijk van den Boekit-Sablat en van de keten, die de vallei van Redjang-Lebong begrenst, uitstrekt, en het stroomgebied van de Rawas en haren rechtertak de Roepit omvat. Alleen het Westelijkste gedeelte van dit landschap, dat tegen het gebergte ligt, bestaat uit geaccidenteerd land. Het overige, verreweg grootste, deel wordt gevormd uit lage en meestal vlakke grondev. De hoogtelijn van $100 \mathrm{M}$. loopt zelfs ver van de Oostkust, boven de samenvloeiing van de Rawas en de Roepit 22 . De rivieroevers uitgezonderd, waarlangs de bevolking zich hoofdzakelijk gevestigd heeft en waar zij ook bij voorkeur hare aanplantingen aanlegt, is het grootste gedeelte van den bodem bedekt met dichte en ongerepte wouden ${ }^{23}$. Opvallend is het veelvuldig voorkomen van kropgezwellen bij beide geslachten in dit landschap. Aldus de getuigenis van den Kontroleur Wesly ${ }^{24}$. Ook Forbes maakt van struma in dit landschap gewag, hoewel volgens hem de gevallen hier minder veelvuldig zijn dan in Makakau en Belalau 25. - Verder schijnt in de vlakke en lage

21 Tijdschrift voor Nederlandsch Indië, jaargang 1857, dl. I, blz. 30 en 31-32.

22 Wesly, De onderafdeeling Rawas, Tijdschrift voor het Binnenlandsch Bestuur, dl. III, blz. 276; Verbeek, Topographische en geologische beschrijving van ZuidSumatra, blz. 15 .

23 Wesly, O. e., blz. 276 en 277.

24 Wesly, O. c., blz. 305-306.

25 Forbes, A naturalist's wanderings in the Eastern Archipelago, blz. 171. 
landen, die het benedenstroomgebied van de Ogan en de Komering vormen, de kwaal zich voor te doen. In zijne "Geneeskundigtopographische schets van de hoofdplaats Palembang", zegt toch de Officier van Gezondheid Lindman: "Het kropgezwel ziet men hier veel, vooral onder het vrouwelijk geslacht; echter komt deze ziekte minder onder de bewoners van Palembang-zelf voor, dan onder die der valleien van de Komering en de Ogan, welke naar de hoofdplaats komen, ou daar handel te drijven" 26. - Eindelijk nog komen kropgezwellen, dikwijls van eene enorme grootte, in enkele streken voor van het stroomgebied der Sipoetih en der Toelang-Bawang, in de Lampongsche Districten. Deze mededeeling, afkomstig van den Officier van Gezondheid Wienecke ${ }^{27}$, vinden wij bij Francis bevestigd. Gelijk bekend is, ontstaat de Toelang-Bawang uit de vereeniging van de Wai-Kiri en de Wai-Kanan, en wordt deze laatste weder gevormd door de samenvloeiing van de Wai-Besai en de Wai-Ompoe. In het gebied van deze Wai-Ompoe nu, met haren linkertak de Tahami, "hebben de meeste menschen kropgezwellen, somtijds grooter dan hun hoofd, en voornamelijk in de kampong Teti-Samang, gelegen ter plaatse waar een klein spruitje zich in de Tahami ontlast" $2 \mathbf{8}$. Ten aanzien van de grondsgesteldheid moet worden opgemerkt, dat verreweg het grootste gedeelte van de Lampongsche Districten, en hiertoe behooren ook de streken waar struma endemisch heerscht, uit weinig geaccidenteerd en over het algemeen laag land bestaat, dat minder dan $100 \mathrm{M}$. boven de zee ligt ${ }^{29}$. Dit lage land, aldus lezen wij, "is over het algemeen vlak. De zeer lage aardruggen, die ' in onderscheidene richtingen loopen, benevens de diep uitgespoelde bedden der rivieren en beeken, geven er niettemin eenige afwisseling aan, en doen, bij lagen waterstand, de lage gronden de gedaante van valleien aannemen. In den regentijd echter, en bij zware afwateringen, worden zij grootendeels overstroomd, en blijven de genoemde lage aardruggen alleenlijk onbedekt; het geheele land

26 Geneeskundig Tijdschrift voor Nederlandsch Indië, dl. IV, blz. 771.

27 Wienecke, Geneeskundig topographische schets van Telok-Betong en Onderhoorigheden, Geneeskundig Tijdschrift voor Nederlandsch Indië, dl. IV, blz. 657 .

28 Francis, Herinneringen uit den levensloop van een Indisch Ambtenaar, dl. I, blz. 215 , noot 1 .

29 Verbeek, Topographische en geologische beschrijving van Zuid-Sumatra, blz. 15. Vervolgt men, op de bij deze verhandeling behoorende kaart (blad IV), de hoogtelijn van 100 M., dan ziet men dat de streken, waar struma endemiseh heersoht (bepaaldelijk het stroomgebied van de Wai-Ompue met de Tahami), buiten die lijn zijn gelegen. 
neemt dan de gedaante aan van eene groote rivierplas met eilanden bezaaid". Overigens bedekken uitgestrekte en aaneengeschakelde, dichte bosschen en wildernissen den bodem, met uitzondering van de, betrekkelijk weinige, bewoonde of in eultuur gebrachte streken ${ }^{30}$.

Het land, onmiddelijk ten Noorden van de Palembangsohe Bovenlanden, is grootendeels eene terra incognita. Uit eene mededeeling, voorkomende in het werk van Marsden, blijkt echter dat struma in deze streek voorkomt, en wel in het ten Zuidoosten van Korintji gelegen Serampei, een zwaar, met dichte bosschen bedekt, bergland, waarin onder anderen een meer voorkomt, de Danau Pau. De mededeeling is van den Luitenant Hastings Dare, die, in het laatst van ]804, aan het hoofd van eene militaire macht, eene expeditie naar deze streken ondernam, ter tuchtiging van eenige kwaadgezinden. Sprekende van zijn verblijf te Rana Ali, in de nabijheid van het meer gelegen, zegt hij: "Of the women whom we saw, almost every one had the goitres or swellings under the throat; and it seemed to be more prevalent with these than with the men. One woman in particular had two protuberances dangling at her neck as big as quart bottles" ${ }^{3 \mathbf{1}}$.

Ten aanzien van het voorkomen van struma in de Padangsche Bovenlanden zijn de berichten veelvuldiger. De Heer Van Hasselt zegt, dat de gezwellen, vaak van zeer grooten omvang, zich vooral in de hoogere streken bij meer gevorderden in leeftijd vertoonen, en het, naar onzen smaak reeds minder schoone, uiterlijk van den Maleier dikwijls afzichtelijk maken ${ }^{32}$. Meer bepaaldelijk heeft deze mededeeling misschien betrekking op het Zuidelijke gedeelte van de Padangsche Bovenlanden, het terrein der werkzaamheden van de Sumatra-expeditie, waarvan de Heer Van Hasselt de leider was. Deze streken bestaan uit het bovenstroomgebied van de Batang-Hari en dat van de Batang-Koeantan ${ }^{33}$. Het eerste, dat is het land besproeid door de Batang-Hari en hare zijtakken de Goemanti met de Sikia, de Siliti en de Sangir, is ten Oosten van den Boekit-Barisan gelegen, tusschen de keten, die den GoenoengPatah-Sembilan, den Goenoeng-Korintji en den Goenoeng-Toedjoeh

so Tijdschrift voor Nedérlandsch Indië, jaarg. 1857, dl. I, blz. 1 en 2.

s1 Marsden, History of Sumatra, blz. 317.

32 Van Hasselt, Volksbeschrijving van Midden-Sumatra, blz. 10.

ss Zie voor het volgende: D. D. Veth, Aardrijkskundige beschrijving van MiddenSumatra, blz. 8 vv. 
verbindt, ten Zuiden, en het zoogenaamde Middengebergte, hetwelk zich van den Goenoeng-Talang in Oostnoordoostelijke richting uitstrekt, ten Noorden. Gaat men dit gebergte, waarvan de pashoogte $1665 \mathrm{M}$. bedraagt, over, dan komt men in het stroomgebied van de Batang-Koeantan, meer bepaaldelijk van hare rechtertakken, de Pelangki, de Soekam en de Koelampi. In deze, uit zwaar bergland bestaande, streek, komt struma voor in de landschappen Soepajang, Alahan-Pandjang en Lolo met Soengei-Pagoe. Het eerste, ten Noorden van het Middengebergte gelegen, omvat hoofdzakelijk het stroomgebied van de Pelangki met haren linkertak, de BatangLawas. Deze Batang-Lawas gaat eerst door een dal, dat over het geheel smal en door steile berghellingen ingesloten is. Later doorsnijdt zij eene driehoekige, van 700 tot $800 \mathrm{M}$. hooge, met vruchtbare sawah's bedekte, vlakte. In deze vlakte is onder anderen het dorp Soepajang gelegen ${ }^{34}$. Ook de Pelangki stroomt over het algemeen door een nauw dal; slechts enkele gedeelten zijn breeder, maar door hooge en steile gebergten begrensd ${ }^{35}$. Tot Alahan-Pandjang behoort in de eerste plaats het plateau van dien naam, en verder de streken langs de Batang-Goemanti en haren linkertak de Sikia. Het plateau van Alahan-Pandjang bevindt zich ter plaatse waar het Middengebergte den Boekit-Barisan ontmoet en is 1500 tot $1600 \mathrm{M}$ hoog. Voor het grootste gedeelte wordt het ingenomen door een meer, den Danau-di-atas. Overigens ontwaart hier het oog slechts sawah's en grasvelden, en worden bosschen in het geheel niet op het plateau gevonden. Van genoemden Danau-di-atas is, gelijk bekend, de Goemanti eene uitwatering. $\mathrm{Na}$ het plateau verlaten te hebben, bereikt de rivier spoedig een komvormig dal, ten Noorden door het Middengebergte, ten Zuiden door een anderen hoogen bergrug ingesloten, welk dal later door een tweede, soortgelijke, gevolgd wordt ${ }^{37}$. Voor het overige hebben de Goemanti en haar linkertak de Sikia, zoowel als beider zijrivieren, een zelfde karakter: smalle dalen, waarvan de bodem geheel door de rivierbedding wordt ingenomen, en steile berghellingen, terwijl slechts op enkele plaatsen bebouwbare dalgrond wordt angetroffen ${ }^{3}$. Lolo en Soengei-Pagoe,

\footnotetext{
34 Veth, 0. c., blz. 11:

s5 Veth, 0. c., blz. 11-12.

so Veth, O. c., blz. 9. Zie ook: Reizen in Midden-Sumatra door de leden der Sumatra-Expeditie, dl. I, blz. 269-270.

37 Veth, O. o., blz. 13.

ss Veth, O. c., blz. 14.
} 
in de derde plaats genoemd, omvatten het lengtedal, dat zich, evenwijdig aan den Boekit-Barisan, van den Danau-di-atas tot den Goenoeng-Korintji uitstrekt, en, in het Noorden, door de Batang-Hari, in het Zuiden, door haren rechtertak de Siliti doorstroomd wordt. De bodem van dit breede en uitgestrekte dal, die aanmerkelijk helt, immers bij Lolo, in het Noorden, 1125, bij Moeara-Laboeh, in het Zuiden, $450 \mathrm{M}$. boven de zee ligt, vormt op enkele plaatsen, zoo ook bij de twee hier genoemde dorpen, eene, met sawahvelden bedekte, vlakte, waaruit zoowel de Boekit-Barisan als het gebergte, dat het dal Oostelijk insluit, tot eene aanzienlijke hoogte, steil oprijst. Elders is het dal met dichte bosschen begroeid, zoodat zijne gesteldheid minder goed te herkennen is, hoewel het schijnt, dat de dalbodem in deze gedeelten meer ongemerkt in de hellingen van het gebergte overgaat ${ }^{39}$. - Uit verscheidene mededeelingen nu blijkt het, dat struma, in de drie hier beschreven landschappen, endemisch heerscht. Zoo maken de leden van de Sumatra-expeditie in het bijzonder gewag van deze kwaal in de dorpen Grabak en Datar, in het smalle dal van de Sikia, op eene hoogte van 720 en $650 \mathrm{M}$. boven de zee, gelegen ${ }^{40}$. "Het weinig innemende van de bewoners dezer streek", aldus lezen wij, "wordt waarlijk niet schooner door de groote kropgezwellen, waarmede velen behept zijn" " '. Evenzoo was de Deensche natuuronderzoeker Bock in de gelegenheid, het veelvuldig voorkomen van struma te constateeren in het dorp Jolo. "Every Monday", schrijft hij, "is market at Lolo. The market was held not 200 yards from my house, and I always attended with my cook to buy provisions. The dealers were mostly women, and a more ugly set of Eve's daughters I don't think I ever saw in my life. The majority of them had large wens in the neck, resembling the throat of the South American howling monkey" 42. Nog zij hier gewezen op eene mededeeling', voorkomende in de "Omschrijving van het summier civiel ziekenrapport van den geneeskundigen dienst op Java, Madura en de Buitenbezittingen over $1858 \%$. In het verslag van den toen te Solok geplaatsten Officier van Gezondheid Neeb, wordt toch

s9 Veth, O. c., blz. 15-17. Zie ook: Reizen in Midden-Sumatra door de leden der Sumatra-Expeditie, dl. 1, blz. 427-428.

40 Voor deze en andere hoogtecijfers in den tekst, zie: Veth, Aardrijkskundige beschrijving van Midden-Sumatra, blz. 3 en 4 , en den bij dit werk behoorenden Atlas, blad I.

41 Reizen in Midden-Sumatra door de leden der Sumatra-Expeditie, dl. 1, blz. 134.

42 Bock, The head-hunters of Borneo, blz. 307.

5e Volgr. V. 
opgeteekend, dat "in bergachtige streken, zooals Alahan-Pandjang en Soepajang, vooral bij vrouwen, kropgezwellen voorkomen" 43. Ook de Heer De Rooy, gedurende geruimen tijjd Kontroleur bij het Binnenlandsch Bestuur in de Padangsche Bovenlanden, bevestigde het veelvuldig voorkomen van struma in Alahan-Pandjang en Soepajang. In het laatstgenoemde landschap trof hij, in de negari TandjongBalit, aan de Poelau, een rechtertak van de Pelangki, gelegen, eene familie aan, waarin de kwaal reeds gedurende drie geslachten erfelijk zou zijn geweest, en waarvan meerdere leden toen ook kroppen hadden. De gezwellen, door den Heer De Rooy waargenomen, deden zich wel eens voor als twee sterk gezwollen, aan elkaar gegroeide en zwaar naar beneden hangende blazen, waarvan de een, de rechtsche, grooter was dan de andere, de linksche, en den omvang meestal had van een kleinen pompelmoes. Intusschen zag de Heer De Rooy ook minder ontwikkelde strumae, die aan de daarmede behepte individuen het voorkomen gaven, als hadden zij een bijzonder dikken hals.

Het is noodig, alvorens de overige streken van de Padangsche Bovenlanden te beschouwen, nog de aandacht te vestigen op het voorkomen van struma in een ander gedeelte van het stroomgebied der Batang-Hari. Een van de takken, welke deze rivier, na de Padangsche Bovenlanden te hebben verlaten, rechts opneemt, is de Djoedjoean. Het land, waardoor deze, tusschen hooge oevers, strooint, is laag gelegen, immers nergens hooger dan $200 \mathrm{M}$., en bestaat, naar het schijnt, voor een niet gering gedeelte uit koepelvormige, zwaar begroeide heuvels, zonder eenig spoor van kultuur, dat de aanwezigheid van menschen verraadt ${ }^{\mathbf{4} 4}$. Eenige dorpen bevinden zich echter langs de rivier-zelve. Een daarvan is Tandjoeng-Alam, 110 M. boven de oppervlakte van de zee gelegen. Van zijn verblijf hier sprekende, zegt de Heer Schouw Santvoort, lid der Sumatraexpeditie: "Reeds had ik opgemerkt, dat in deze streken veelvuldig kropgezwellen voorkomen van buitengewonen omvang; maar zoo groote als die van de vrouw, kinderen en zusterszoon van mijn gastheer had ik nog niet gezien. Hun geheele gelaat viel letterlijk weg achter het vooruitstekende gezwel, dat bij sommigen drie verhevenheden vertoonde en aan het gelaat iets walgelijks, bijna iets dierlijks gaf; terwijl hunne stem daardoor een eigenaardig schor en diep keel-

4s Geneeskundig Tijdschrift voor Nederlandsch Indië, dl. IX, blz. 750 .

4 Reizen in Midden-Sumatra door de leden der Sumatra-Expeditie, dl. I, blz. 66. Voor de hoogteoijfers zie den in noot 40 bedoelden atlas. 
gelnid had gekregen. De kwal is erfelijk, vertelde men mij, on vertoont zieh bij kinderen op veertienjarigen en selfs op nog jengdiger leeftijd ". Opmerkelijk is het zeker, merkt de Heer Sehouw Santwoort verder op, dat in het naburige, Rantan-Tkir geen kropgeswellen voorkomen ${ }^{45}$.

Keeren wij terug nas de Padangsche Bovenlanden. Nog van enkele streken in dit gebied wordt ous het voorkomen van struma berieht. Zoo vond de Heer De Rooy, dien wij zooeven noemden, deze kwaal in Tanah-Datar, hoewel in veel mindere mate dan in Alahan-Pandjang en Soepajang. De terreinformatie van dese landstreek wordt beheerscht door de Ombilin en hare voornasuste linkertakken. De Ombilin-zelve heeft alleen boven de kampong Telaweh nu en dan, namelijk plaatselijk, een dalbodem, doch stroont beneden dit dorp door een plateau met steile bergreeksen on tal van diepe ravijnen en kloven, het zoogenaamde Ombilin-kolenveld. Wat de zijtakken betreft, wordt de voornaamste daarvan, de Sello, in haren kronkelenden loop, ter linkerzijde begrensd door een rotsachtig gebergte met somtijds loodrechte wanden. Reehts van de rivier breidt zich echter eene groote vlakte uit tot aan den voet van den Merapi, op welke vlakte, 458 M. boven de zee, Fort Van der Capellen gelegen is ${ }^{46}$. Eene andere landstreek, die hier genoemd moet worden, is Batipoe en de X Kota. Ten Noorden door den Merapi, ten Zuiden door den Talang afgesloten, strekt zich een breed dal uit, dat Westelijk door den Boekit-Barisan, Oostelijk door een lagen bergring, waardoor het van Tanah-Datar wordt gescheiden, begrensd wordt. Het Noordelijkste, minst breede, gedeelte van dit dal is zeer geaccidenteerd, en helt in algemeenen zin van Noord naar Zuid, meer benedenwaarts van Noordwest naar Zuidoost. Aan den voet van dit hellend terrein en in het verlengde daarvan ligt het meer van Singkarah 47. In dit landschap nu, dat administratief de afdeeling Batipoe en de X Kota vormt met de hoofdplaats Padang-Pandjang, 783 M. boven de zee, komt, volgens eene mededeeling van den alhier in 1854 geplaatsten Officier van Gezondheid Kervel, struma eudemisch voor, en wel meer bij mannen dan bij vrouwen 13 . -

45 Reizen in Midden-Sumatra door de leden der Sumatra-expeditie, dl. I, blz. 68.

46 Cluysenaer, Mededeelingen omtrent de topographie van een gedeelte der Padangsehe Boven- en Benedenlanden, Tijdsehrift van het Aardrijkskundig Genootschap, dl. III, blz. 233.

47 Cluysenaer, O. o., blz. 231.

48 Geneeskundig Tijdschrift voor Nederlandsch Indië, dl. IV, blz. 914. 
Noordelijk gaande, komt men op het plateau van Agam, waar de kwaal, gelijk Dr. Ludeking dit uitdrukkelijk verklaart, zich weinig voordoet 49. Anders in de Noordwestelijk van Agam gelegen onderafdeeling VIII Kota en VII Loerah, waarvan Palembajan, dat $753 \mathrm{M}$. hoog ligt, de hoofdplaats is. Onder de kwalen, waarvan men bij de bevolking dezer onderafdeeling "een overgroot aantal" gevallen ziet, noemt de Heer Harrebomée ook kropgezwellen op ${ }^{50}$. Evenzoo wordt in Bondjol, 220 M. boven de zee, in het nauwe en diepe dal van de Alahan-Pandjang gelegen!, struma veelvuldig aangetroffen ${ }^{51}$, terwijl zij, volgens eene mij door den Heer Visser, laatstelijk Assistent-Resident van de L Kota, gedane mededeeling, ook in de angrenzende Ophir-districten niet zeldzaam is en vooral zich bij vrouwen vertoont. - Nog treft men in dit gedeelte van Sumatra kropgezwellen aan in de laras of het district Kapoer-nan-sembilan. De Assistent-Resident Tromp, die als Kontroleur in de onderafdeeling Poear-Datar, waartoe dit district vroeger behoorde ${ }^{51 \mathrm{a}}$, geplaatst was, schrijft mij, dat de kwaal zich meer bij vrouwen dan bij mannen voordoet en ook bij jonge meisjes wordt gezien. De gezwellen ontwikkelen zich van lieverlede en krijgen soms enorme afmetingen. Ook de Heer De Rooy constateerde in dit district, zoowel als in de aangrenzende laras Mahi, het voorkomen van struma, en, evenals de Heer Tromp, meer bij vrouwen dan bij mannen. De beide hier genoemde districten behooren tot het bovenstroomgebied der KamparKanan. Dit gebied bestaat uit een plateau, dat naar het Oosten geleidelijk afdaalt, doch waarvan de Westelijke rand zich steil verheft uit het dal van de evengenoemde Alahan-Pandjang. Het terrein is zeer geaccidenteerd, afgebroken door diepe en nauwe kloven, waardoor de Kampar-Kanan en hare bijrivieren stroomen, en door bergen, die aan eene of meer zijden loodrechte wanden bezitten. Van de laras of het district Mahi nu is het voornaamste, dat is het meest bevolkte, gedeelte eene door dergelijke bergen geheel omgeven vlakte, $250 \mathrm{M}$. boven de zee gelegen, doorstroọmd door de rivier van dien naam, een rechtertak van de Kampar-Kanan.

\footnotetext{
49 Ludeking, Natuur- en geneeskundig topo'raphische schets der Assistent-residentie Agam, Geneeskundig Tijdschrift voor Nederlandsch Indiē, dl. IX, blz. 99.

50 Harrebomée, Aanteekeningen op A. L. Van Hasselt's „Volksbeschrijving van Midden-Sumatra», Indische Gids, jaarg. 1887, dl. I, blz. 88.

51 Geneeskundig Tijdschrift voor Nederlandsch Indië, dl. V, blz. 1195.

${ }^{51} a \mathrm{Nu}$ behoort Kapoer-nan-sembilan tot de onderafdeeling Pangkalan-KotaBaroe en XII Kota-Kampar.
} 
Deze vlakte doet zich geheel als een dalketel voor, daar zij aan alle kanten gesloten schijnt, terwijl de Mahi haar door eene nauwe spleet in den bergwand betreedt en door eene even nauwe spleet weder verlaat. Wat Kapoer-nan-sembilan betreft, is de meest bewoonde streek hiervan een breed, door steile hoogten begrensd dal, dat de Kapoer-Gadang, eveneens een rechtertak van de Kampar-Kanan, heeft uitgespoeld, van welk dal het hoogere gedeelte 144 M., het lagere $90 \mathrm{M}$. boven de zee ligt ${ }^{52}$.

Noordelijk van Bondjol, komen wij in het, door Bataks bewoonde, landschap Mandaïling, hoofdzakelijk bevattende de breede, door een $900 \mathrm{M}$. hoog gebergte begrensde, vallei van de Batang-Gadis en de Batang-Angkola. Het voorkomen van struma in dit landschap vinden wij in de eerste plaats geconstateerd in de "Fragmenten uit de reizen en onderzoekingen in Sumatra" van Dr. Müller en Dr. Horner, leden der Natuurkundige Commissie in Nederlandsch Indië. Van hun verblijf te Botoeng, gelegen tusschen Pakanten en Moeara-Sipongi ${ }^{\mathbf{5} 3}$, heet het: "Bij het doorwandelen van deze kampong bemerkten wij verscheidene menschen met kroppen, een verschijnsel dat in geheel Mandaïling niet zeldzaam is". Den volgenden dag in het dorpje Banir-Pandjang komende, vonden zij, onder het kleine getal inwoners, "vijf vrouwen en én knaap met vrij groote kroppen" $\mathbf{5 4}$. Verder hebben wij hier te wijzen op eene mededeeling van den Amerikaanschen natuuronderzoeker Bickmore, die, op zijne reis van Fort De Kock naar Padang-Sidempoean, te MoearaSipongi vele strumalijders zag. "Het was", aldus schrijft hij, "hier marktdag, en daar wij eenigen tijd wilden uitrusten, had ik eene goede gelegenheid om het volk waar te nemen.... Een groot aantal personen van beide seksen, en zelfs sommige kinderen, waren behept met een afzichtelijk ongemak , namelijk kropgezwellen" ${ }^{55}$. Hoewel,

52 Verbeek, Topographische en geologische beschrijving van een gedeelte van Sumatra's Westkust, blz. 588, 590 en 628-629. Zie ook: Fennema, Topographische en geologische beschrijving van het Noordelijke gedeelte van het Gouvernement Sumatra's Westkust, Jaarboek van het Mijnwezen in Nederlandsch Oost-Indië, jaarg. 1887, Wetenschappelijk gedeelte, blz. 135 en 137. - Men zie verder noot 120 hierbeneden.

58 Dat Botoeng hier gelegen is, merkt Fennema, in zijne, in de voorgaande noot geciteerde, verhandeling (blz. 167), op.

54 Müller en Horner, Fragmenten uit de reizen en onderzoekingen in Sumatra, Bijdragen tot de T. L. en Vk. van Nederl. Indië, dl. II, blz. 235 en 236.

55 Bickmore, Reizen in den Oost-Indischen Archipel, dl. II, blz. 130-131 (van de Hollandsche vertaling van Prof. De Hollander). 
blijkens de geciteerde woorden van Horner en Müller, in geheel Mandaïling niet zeldzaaam, schijnt de kwaal zich toch voornamelijk in het Zuidelijkste, dat is het hoogste en smalste, gedeelte van het dal van de Batang-Gadis voor te doen, want hier zijn Pakanten en Moeara-Sipongi, respectievelijk 815 en $635 \mathrm{M}$. boven de zee, gelegen. Misschien zijn ook door Willer meer bepaaldelijk deze streken bedoeld, waar hij in zijne beschrijving van Mandaïling en Portibi zegt, dat "in hooge districten men, als in andere berglanden, menigvuldige kropgezwellen ziet” $\mathbf{5 6}$.

Eene uitgetrekte strumazone vindt men op Sumatra verder in het, eveneens door Bataks bewoonde, bovenstroomgebied van de Pane en de Bila. Zoo zag ik vele lijders in de zoogenaamde HaranganSipirok, het bergland, dat het plateau van Sipirok Oostelijk begrenst en doorstroomd wordt door de Aek-Hiloeng, die zich in de Aek-SiOmbal, een rechtertak van de Pane, stort. Verder heerscht de kwaal endemisch te Napa-Gadoeng-Laoet, aan de Pane-zelve gelegen ${ }^{57}$. Niet minder is dit het geval in Tano-Rambe-Djae, het stroomgebied van de Aek-Asaan, met haren linkertak de Aek-Soehat, en van de Aek-Hiloeng en de Aek-Parmeraan, welke met eene vierde rivier, de Aek-Goelangan, in één punt samenkomende, de Soengei-Kanan, een rechtertak van de Pane, vormt. "Het is een eigenaardig gezicht", schrijft de Heer Neumann, "om van eene hoogte af het land te overzien, dat door die rivieren doorstroomd wordt. De kloven en valleien, in welke zij zich bewegen, strekken zich als spaken van een wiel in alle richtingen uit. De tusschenliggende bergen, eerst smal, breiden zich langzamerhand uit, totdat zij in het hooge ketengebergte eene breede basis vormen. Donkere schaduwen leveren die bergen met hunne zware bosschen. Fantastisch steken enkele bergspitsen omhoog, ontbloot van boschgroei, maar bedekt met laag struikgewas en grassen, waarboven enkele bamboestoelen hunne sierlijke halmen buigen. Verder ziet men neer op het lage gebergte, dat telkens verschillende kleurschakeeringen te aanschouwen geeft, al naarmate het land bebouwd, kort of lang geleden door de cultuur verlaten werd, of nog in maagdelijke woestheid nederligt. Daartusschen in weer alang-alang-velden, het toonbeeld der wraak van de tropische

56 Willer, Verzameling der Bataksehe wetten en instellingen in Mandheling en Pertibie, gevolgd van een overzicht van land en volk in die streken, Tijdschr. v. Nederl. Indië, jaarg. 1846, dl. II, blz. 262.

57 Neumann, Het Pane- en Bila-stroomgebied, Tijdschr. v. h. Nederl. Aardrijkskundig Genootschap, 2e serie, dl. III, ble. 221 vlg. 
natuur, wanneer hare orde verbroken wordt. Door de zon verlicht, blinkend als gepolijst staal, kronkelen de rivieren zich tusschen dat verschillende groen, eerst ver uit elkander, elkander hoe langer hoe meer naderende, om eindelijk ééne lijn te vormen, de SoengeiKanan, die, glinsterend als zilver, in eene nauwe kloof verdwijnt" 5 s. Zeer algemeen zijn kropgezwellen eindelijk in Tano-Rambe-Djoeloe, omvattende het stroomgebied van de Aek-Pandjamaan tot aan de Aek-Balimbing, twee rechtertakken van de Bila, en in GoenoengTinggi, gelegen aan de Bila-zelve. Doch het is niet alleen in het bergland, dat struma in dit gedeelte van Sumatra endemisch heerscht. Zuidoostelijk van Tano-Rambe-Djae strekt zich, scherp afgescheiden van het hooggebergte, hetwelk in den regel met steile wanden eindigt, bewesten de zooeven genoemde Soengei-Kanan, een heuvelland uit, dat zich niet meer dan 100 M. boven de zee verheft 59 . Vele Bataks nu van deze landstreek, zoowel mannen als vrouwen, zijn ontsierd door kropgezwellen 60 . Die gezwellen, barut, zooals zij in het Bataksch heeten, zijn, deelt de Heer Neumann mede, van verschillenden vorm en dikwijls onoogelijk groot. Zoo was er eene vrouw, die, bij het loopen, het gezwel steeds met de handen moest steunen, en had een man een krop, die tot aan de tepels der borsten reikte. Men meent dat de kwaal ook wel eens van ouders op kinderen overgaat. Deze worden daarmede echter niet geboren. Intusschen zag de Heer Neumann niet zelden kinderen van vier tot vijf jaren met sterk gevulde halzen, het begin van zulke gezwellen. De stem van den Batak is van nature hard, en wordt op lateren leeftijd heesch en in de hoogste mate onwellnidend. Strumalijders brengen het geluid gedeeltelijk door den neus voort. Nog onaangenamer zijn de geluiden, welke zij slapende maken. Hunne ademhaling is gewoonlijk zwaar, maar in den slaap gaat zij nog gepaard met eene soort van blaffen en met andere onwelluidende klanken, die niet nader zijn aan te duiden. Deze menschen zijn zeer te beklagen, want vooral als de kroppen zwaar zijn, kunnen zij moeielijk zwaren arbeid verrichten en moeielijke of langdurige tochten maken.

58 Neumann, Het Pane- en Bila-stroomgebied, Tijdschr. v. h. Nederl. Aardr. Genootsch., 2e serie, dl. II, blz. 47.

59 Neumann, O. c., blz. 31. Zie ook van denzelfden schrijver: Schets der afdeeling Laboean-Batoe, Tijdschr. v. Ind. T. L. en Vk., dl XXVI, blz. 439-440.

60 Neumann, Schets der afdeeling Laboean-Batoe, blz. 449. Zie ook: Larive, Eenige aanteekeningen, gehoulen op een reisje naar en door de bovenstreken van Kota-Pinang, Tijdschr. v. Ind. T. L. en Vk., dl. XVII, blz. 265. 
Zij geraken zeer spoedig buiten adem. In het stervensuur is hun deze drukking op de ademhalingswerktuigen bovendien zeer smartelijk 61 .

Nog een tweetal andere streken op Sumatra hebben wij te vermelden, waar struma endemisch voorkomt. In de eerste plaats de binnenlanden van Deli en Serdang. "Swellings of the throat called wens, are very common amongst the inhabitants who live high up the river", zegt reeds Anderson, die deze landschappen in 1823 bezocht ${ }^{62}$. Door Dr. Hagen vinden wij deze mededeeling bevestigd. "Die Binnenländer der Sultanate Deli und Serdang", schijft deze, "werden von den Orang-Dusun bewohnt, den Leuten der Vorberge. Sie erstrecken sich von der Malaiengrenze nur bis an den Rand der Hochebene von Toba, nicht auf diese selbst" 62a. Onder deze Dusun-Bataks nu vond Dr. Hagen "ungemein viele Kröpfe, was bei den Völkern auf der Hochebene vollständig fehlt" ${ }^{63}$. - Het andere strumagebied, door ons bedoeld, is de Petalangan. Deze is gelegen tusschen de Siak en de Kampar en bestaat uit eene aaneenschakeling van hooge en lage gronden, hier en daar afgewisseld door moerassen, die dikwijls een kwartieruur gaans lang zijn. De hooger gelegen grond, die nu eens een dicht, ondoordringbaar woud, dan weder onafzienbare alang-alang-velden, overblijfsels van vroegere ladangs, of terreinen, begroeid met laag kreupelhout of varensoorten, te aanschouwen geeft, is licht heuvelachtig ${ }^{64}$. De bewoners van deze streken zijn de zoogeuaamde Orang-Talang. De mannen, doch voornamelijk de vrouwen, zijn behept met kropgezwellen, die zich reeds bij kinderen op tien- of elfjarigen leeftijd beginnen te ontwikkelen 65 .

Gaan wij nu over naar Borneo. In enkele streken van dit uitgestrekte eiland komt struma endemisch voor. Zoo in het district DoesonTimor, behoorende tot de residentie Zuider- en Ooster-Afdeeling. Dit

61 Neumann, Het Pane- en Bila-stroomgebied, Tijdsohr. v. h. Nederl. Aardr. Genootsch., 2e serie, dl. III, blz. 222.

62 Anderson, Mission to the East Coast of Sumatra, blz. 268.

69a Hagen, Fine Reise nach dem Toba-See in Zentralsumatra, Petermanns Mitteilungen, dl. XXIX, blz. 44.

63 Hagen, t. a. p.

o4 Van Rijn van Alkemade, Reis van Siak naar Poelau Lawan, Tijdschrift v. h. Nederl. Aarkrijkskundig Genootschap, 2e serie, dl. III, blz. 131 en 132. Zie ook de in de volgende noot aangehaalde verhandeling, blz. 140.

6s Tocht naar het rijk van Poeloe-Lawan, door een oud-ambtenaar van het Mijnwezen, Tijdsohrift voor het Binnenlandsoh Bestuur, dl. III, blz. 141-142. 
district omvat het stroomgebied van de Patai en de Karau, twee linkertakken van de Barito. In de nabijheid van den hoofdstroom is het land laag en moerassig, in den regentijd aan overstroomingen onderhevig en bedekt met dichte bosschen. In Oostelijke richting voortgaande, ziet men echter de bodem allengs hooger worden. Aanvankelijk verheft zich het terrein zacht en golfsgewijze over de moerassige laaglanden, later ontmoet men kleine heuvels. De plateauvormige ruggen dezer heuvels, djowong geheeten, zijn in den regel slechts met een dun woud begroeid, of vormen, voor zoover zij vroeger ten behoeve van de rijstkultuur ontgonnen zijn geweest, velden bewassen met laag kreupelhout, doormengd met massa's van bamboes, varens, riet- en grassoorten, bepaaldelijk glagah en alang-alang, en onderscheidene stekelplanten. In tegenstelling van deze schrale vegetatie der djowong's, vertoonen de loau's, de dalen tusschen de heuvels, die, ten gevolge van de ongenoegzame afwatering, moerassig zijn, om de woorden van Grabowsky te gebruiken, "ein Bild so spezifisch-tropischer Urwaldüppigkeit, dass das Auge im Anfange Einzelheiten in diesem Chaos von riesenhaften, über und über mit den herrlichsten Schmarotzern bedeckten Bäumen, diesem Gewirr von Lianen, diesem Reichthum an Farbennüancen kaum zu unterscheiden vermag". Ook dit gebied wordt gedurende den regenmoesson voor een groot gedeelte overstroomd, zoodat alleen de heuvels met hunne ruggen als eilanden boven het water uitsteken. Verder Oostelijk wordt het terrein meer bergachtig: de moerassen worden verdrongen door het droge land, en de bodem verheft zich in groepen van bergen, die eene hoogte van ruim 300 M. bereiken ${ }^{66}$. Dit district wordt bewoond door den Dajakschen stam der Olo-Maanjan, wier dorpen bijna allen in het Oostelijke heuvelland gevonden worden, meestal op de heuvelszelve, eenige honderde schreden van de rivieren verwijderd $\mathbf{6 7}^{7}$. Bij deze Dajaks nu komt struma veelvuldig voor. "Entstellt", lezen wij bij Grabowsky, "sind viele Männer und Frauen durch grosse Kröpfe" $6 \mathbf{3}$. Hetzelfde vinden wij bij andere schrijvers geconstateerd. Zoo viel den Heer Bangert, die in 1857 als civiel gezaghebber deze streken bereisde, bepaaldelijk in het dorp Sangarwasi, aan den bovenloop der Patai, het betrekkelijk groot getal vrouwen, zelfs jonge meisjes,

66 Schwaner, Borneo, dl. I, blz. 91, 93 en 97; Grabowsky, Der Distrikt DussonTimor in Südost-Borneo und seine Bewohner, Ausland, jaarg. 1884, blz. 445 vlg.

67 Grabowsky, O. c., blz. 446.

68 Grabowsky, O. c., blz. 448. 
op, die aan kropgezwellen leden 6 9. Ook de Officieren van Gezondheid Van Goens en Van der Myll Dekker, die, respectievelijk in 1860 en 1862, te Tamejang-Lajang, eveneens aan de Patai gelegen, vertoefden, maken van het voorkomen van struma hier gewag. Eerstgenoemde zegt voornamelijk bij vrouwen vele gevallen te hebben waargenomen $\mathbf{7 0}$.

Struma wordt in Borneo's Zuider- en Ooster-Afdeeling verder nog gevonden in de assistent-residentie Martapoera. Deze bestaat, behalve uit het landschap Tanah-Laoet, waarop wij straks terugkomen, uit het gebied tusschen de beneden-Barito en den Goenoeng-Meratoes, het waterscheidend gebergte tusschen de rivieren, die Oostwaarts naar zee vloeien, en die, welke in Westelijke richting gaan en zich in evengenoemden hoofdstroom ontlasten. Tot deze laatsten behooren de Riam-Kiwa en de Riam-Kanan, die zich later vereenigen en zoo de Martapoera-rivier vormen. Ten anzien van de terreinformatie valt op te merken, dat het Oostelijke gedeelte bergachtig is en hoofzakelijk ingenomen wordt door de uitloopers van den Goenoeng-Meratoes en vooral door eene van dit gebergte in Zuidwestelijke richting, tusschen de Riam-Kiwa en de Riam-Kanan, zich uitstrekkende, 240 tot $360 \mathrm{M}$. hooge, met zware bosschen bedekte, keten, de GoenoengBobaris. Ten Westen van den Goenoeng-Meratoes en ten Noorden en Noordwesten van den Goenoeng-Bobaris, vindt men een heuvelland, uit toppen van 30 tot $75 \mathrm{M}$. bestaande, welke soms in langere of kortere reeksen achter elkander liggen, maar dikwijls ook geheel zonder regel het golvend terrein samenstellen. Verder Westelijk wordt de bodem vlak. Zoowel deze vlakke streken als het heuvelland zijn schraal begroeid, niet zelden, over groote uitgestrektheden, alleen met alang-alang-velden bedekt. In de nabijheid van de Barito is de grond laag en hier en daar moerassig $\mathbf{7 1}^{1}$ Omtrent het voorkomen van struma in dit gebied hebben wij allereerst de mededeeling van den Officier van Gezondheid Deelken, die

60 Bangert, Verslag der reis in de binnenwaarts gelegen streken van DoesoenIlir, Tijdsohr. v. Ind. T. L. en Vk., dl. IX, blz. 165.

70 Van der Myll Dekker, Topographische schets van Mengkatip en Sihong, en Van Goens, Schets eener geneeskundige plaatsbeschrijving van Tameang-Lajang, Geneeskundig 'Tijdschrift v. Nederlandsch Indiö, dl. X, blz. 558, en dl. XI, blz. 104. 71 Sohwaner, Borneo, dl. I, blz. 53 vlg.; Sal. Müller, Reizen en onderzoekingen in den Indisehen Arohipel, dl. I, blz. 274 vlg., 279 vlg., 281 vlg. en 291 vlg.; Verbeek, Geologische beschrijving der districten Riam-Kiwa en Kanan, Jaarboek van het Mijnwezen in Nederlandsch Oost-Indië, jaarg. 1875, dl. I, blz. 13-15. Zie ook de in de volgende noot aangehaalde verhandeling, blz. 88, 89 en 91 . 
in 1862 te Rantau vertoefde. Deze plats is in het district Margasari en Benoewa-Ampat gelegen, aan den Westelijken rand van het heuvelland. Kropgezwellen, zegt de Heer Deelken, zijn hier niet zeldzaam, vooral bij het vrouwelijke geslacht ${ }^{72}$. Verder wordt de kwaal nog aangetroffen in de Oostelijke bergstreken. De GoenoengMeratoes wordt namelijk, zoowel aan de zijde van het bovenstroomgebied van de Riam-Kiwa en de Riam-Kanan als aan den anderen kant, waar de naar de Oostkust vloeiende Koesan- of Pagatanrivier ontspringt, bewoond door de zoogenaamde Orang-Bukit, een stam die ook Noordelijker te Mindai, in de assistent-residentie Amoentai, langs den bovenloop der Batang-Alai, een der bijstroomen van de Bahan of Negara, gevestigd is. Bij deze Orang Bukit nu, bepaaldelijk van het brongebied der Koesan of Pagatan, vond de Heer Von de Wall, onder mannen zoowel als vrouwen, vele kropgezwellen ${ }^{73}$. Ook de Heer Grabowsky, die deze menschen, zoowel te Mindaí als aan de Riam-Kiwa, bezocht, zegt dat strumalijders onder hen "sehr häufig" zijn ${ }^{74}$. - Tot de assistent-residentie Martapoera behoort nog het zooeven genoemde landschap Tanah-Laoet. Van dit landschap zijn de Zuidelijke, doch vooral de Westelijke kustlanden laag en vlak of zeer zacht golvend, hier en daar moerassig en alleen met gras en riet begroeid, of dor en droog en met uitgestrekte alang-alang-velden bedekt, waartusschen zich eenige kleine boschgroepen bevinden 75 . Het midden- en oostelijke gedeelte daarentegen is heuvel- en bergachtig en met dichte wouden bezet. Voornamelijk heeft men hier eenige even-

72 Deelken, Geneeskundige plastabeschrijving van het distriet Margasari, Goneeskundig Tijdschrift $\vee$. Nederlandsch Indië, dl. XI, blz. 96.

73 Von de Wall, Overzicht van het rijk van Koetei on de Oostkust van Borneo, Indisch Archief, jaarg. 1850, dl. III, blz. 480.

74 Grabowsky, Die Orang-Bukit oder Bergmenschen von Mindai in Siidost-Borneo, Ausland, jaarg. 1885, blz. 785. Er staat eigenlijk, dat "Oretins unter den Bukits sehr häufig" zijn. Dit is echter een lapsus enlami, zooals de Heer Grabowsky mij schrijft. "Cretinismus", merkt hij op, "habe ioh nioht bei den Bukits beobachtet, sondern nur Kröpfe, die ich auch bei den Maanjan erwähnt habe". Bij andere Dajaksche stammen - om dit hier nog op te merken - zooals de Olo-Ngadju en de Olo-Ot-Danom, zijn den Heer Grabowsky, zooals hij mij verder mededeelt, "Leute mit Kröpfen nicht aufgefallen ".

75 De alang-alang-vlakten van Tanah-Laoet behoorden tot de rijkste jachtvelden van de voormalige Sultans van Bandjermasin. Het is geene zeldzasmheid, zegt Müller (Reizen en onderzoekingen in den Indisehen Arohipel, dl. I, blz. 307), daar troepen van 50, 80 tot 100 of meer herten aan te treffen, en hen, als kudden schapen, de met jonge halmen bedekte vlakten te zien afweiden, waartoe het oude alang-alang nu en dan wordt afgebrand. 
wijgdig met den Goenoeng-Bobaris loopende bergreeksen te onderscheiden, waardoor lange dalen gevormd worden, die de hoofdrichting der afwatering aangeven. De hoogste top, de Goenoeng-Sakoembang, meet, volgens Sal. Müller, 967 M. ${ }^{76}$. Bij de bewoners van dit landschap doen zich, aldus deelt de Officier van Gezondheid Van Lokhorst mede, kropgezwellen dikwijls voor, vooral bij vrouwen. Volgens sommigen worden in het bijzonder zij, welke meermalen gebaard hebben, daardoor aangetast. Te Habalang, in het Oostelijke bergland, aan den voet van den zooeven genoemden Goenoeng-Sakoembang, doch niet hooger dan $60 \mathrm{M}$. boven de zee, gelegen $\mathbf{7 7}$, moet de kwaal zeer algemeen zijn. Aan den Heer Van Lokhorst werd door inlanders verzekerd, dat hier, van de tien personen, acht met struma behept zouden zijn ${ }^{\mathbf{7 8}}$.

Alvorens dit gedeelte van Borneo, dat is de residentie Zuideren Ooster-Afdeeling te verlaten, hebben wij nog de aandacht te vestigen op een bericht van den Deenschen natuuronderzoeker Bock. Gelijk bekend is, ondernam deze, in 1880 , in opdracht van de Nederlandsch Indische regeering, eene reis in het rijk van Koetei. Later trok hij, na de Mahakam tot Moeara-Pahoe te zijn opgevaren, overland naar de Teweh, welke rivier hij tot aan hare vereeniging met de Barito volgde, om daarna dezen stroom tot Bandjermasin af te zakken. Zoowel bij de Maleiers als bij de Dajaks nu vond Bock vele kropgezwellen. "It is no exaggeration", merkt hij op, "to say that every third woman is afflicted with a protuberance in the throat, varying from the size of an apple to that of a child's head" 79. Te betreuren is het, dat Bock niet nauwkeurig de plaats opgeeft, waar door hem die veelvuldige gevallen van struna zijn gevonden. Van de Dajaks bezocht hij onder anderen de Modang's en de Longwai's. De Heer Von de Wall, die eveneens in het gebied van deze twee Dajaksche stammen heeft gereisd, maakt echter in zijn uitvoerig verslag in het geheel geen gewag van de

76 Schwaner, Borneo, dl. I, blz. 54; Sal. Müller, Reizen en onderzoekingen in den Indischen Archipel, dl. I, blz. 293 vlg., 302 vlg. en 306 vlg.; Posewitz, Borneo, blz. 74; Verbeek, Geologische beschrijving der districten Riam-Kiwa en Kanan, Jaarboek van het Mijnwezen in Nederl. Oost-Indië, jaarg. 1875, dl. I, blz. 14. 77 Sal. Müller, O. o., blz. 297.

78 Van Lokhorst, Sohets eener geneeskundige plastsbeschrijving der afdeeling Tanah-Laoet, Geneeskundig Tijdschrift v. Nederl. Indië, dl. X, blz. 239.

79 Bock, The head-hunters of Borneo, blz. 213, waarmede ook blz. 182 te vergelijken is (van de Hollandsche uitgave blz. 90 en 76). 
kwaal. Evenmin kan het bericht van den Heer Bock betrekking hebben op de Bahan's, daar de Heer Tromp, welke geruimen tijd Assistent-Resident van Koetei was, mij schreef, onder hen wel "menschen met kropgezwellen te hebben gezien, maar niet in frappanten getale". Er blijft dus alleen over om aan te nemen, dat de vele strumalijders door Bock zijn waargenomen op zijn tocht van MoearaPahoe naar de Teweh, bij de Bĕntian- en de Běnoewa-Dajaks, dan wel bij de Orang-Bukit van Mindai, die hij later van Bandjermasin uit bezocht.

Behalve in de Zuider- en Ooster-Afdeeling, komt ook in enkele streken van de Wester-Afdeeling van Borneo en in het aangrenzende gebied van Sarawak struma endemisch voor. Onder de verschillende berichtgevers noemen wij in de eerste plaats Ritter. Zonder eene bepaalde streek op te geven, spreekt deze van de menigte kropgezwellen, die men onder de Dajaks vindt, sommige zelfs van verbazenden omvang, welke gezwellen geheel hereditair zijn en zich in familiën, eens daarmede behept, geregeld voortplanten $\mathbf{s} 0$. De Heer Van Lynden zegt dat kropgezwellen zeer dikwijls angetroffen worden bij de Dajaks van Melawi ${ }^{81}$. De Melawi is, gelijk men weet, een linkertak van de Kapoeas. Het land, waardoor de rivier stroomt, is eene breede, door vrij hooge bergketens ingesloten, vallei, waarvan de bodem op sommige plaatsen zacht golvend, op andere duidelijk met heuvels bezet is. Van deze heuvels, waarop niet zelden de dorpen gebouwd zijn, loopen de glooiingen zacht naar de hoogte, en zijn de ruggen als vlakten en terrassen gevormd. Eerst in het laatste gedeelte van haren loop, kort voor hare vereeniging met de Kapoeas, gaat. de Melawi door vlakke en lage, hier en daar moerassige, oeverlanden ${ }^{\mathbf{8 2}}$. Ook in de streek, doorstroomd door de Sipaoek, eveneens een linkertak van de Kapoeas, schijnt struma voor te komen, daar wij toch vermeld vinden, dat an het water van de minerale bronnen, die in de nabijheid van deze rivier worden aangetroffen, eene geneeskrachtige werking tegen de kwaal wordt toegeschreven ${ }^{\mathbf{8} 3}$. Een ander bericht, waarop hier de aandacht moet worden gevestigd, is van den Officier van Gezondheid Hunnius. Deze nam op eene reis naar de boven-Kapoeas, in 1862, in het

\footnotetext{
80 Tijdschrift voor Nederl. Indië, jaarg. 1844, dl. III, blz. 217.

81 Van Lynden, Aanteekeningen over de landen van het stroomgebied der Kapoeas, Natuurkundig Tijdschrift v. Nederl. Indië, dl. II, blz. 590.

82 Schwaner, Borneo, dl. II, blz. 181, 182, 183, 184, 186 en 189.

ss Zie blz. 422 hierbeneden.
} 
dorpje Poeloe-Matjan ${ }^{\mathbf{8 4}}$, bij het meer Seriang, aan den voet van het Batang-Loepar-gebergte, eenige bejaarde vrouwen met middelmatig groote kropgezwellen waar ${ }^{\mathbf{8 5}}$. Meer algemeen komt de ziekte voor bij de Land-Dajaks, speciaal bij die, welke het waterscheidend gebergte tusschen Sarawak en Sanggau bewonen. De Heer Denison, die deze Dajaks in 1874 bezocht ${ }^{\mathbf{8 6}}$, constateerde, van het Noorden komende de eerste gevallen van struma in het dorpje Matan, in het brongebied van de Sarawak-rivier gelegen. "The situation of this little village", dus schrijft hij, is "very picturesque, standing as it does on a clearing in the midst of a forest of old jungle, and surrounded by the Si-Bungo range 3000 feet in height on one side, and by the S'Bri and Seraung mountains (the latter 2650 feet high) on the other" ${ }^{\mathbf{8} 7}$. Het dorpje was eerst een tweetal jaren geleden gesticht. "The people seemed in good health, and had no complaints to bring before my notice, here for the first time I noticed wen or goitre, of which there were two or three cases " $\mathbf{8 \mathbf { 8 }}$. Endemisch kan dus de struma hier nog niet gezegd worden te heerschen. Zuidwaarts is dit echter wel het geval. Toen Denison het waterscheidend gebergte was overgetrokken, vond hij namelijk in Sanggau, in het brongebied van de Sikajam $\mathbf{8 9}$, een woest en bijna onbegaanbaar bergland 90 , in verschillende dorpen, "a good deal of goitre". Weinig anlokkelijk is zeker de beschrijving door hem van het hoofd van een dier dorpen gegeven. "Covered from head to foot with korap ${ }^{91}$ in its worst form, his

84 Op de kaart van Borneo, in den atlas van Stemfoort en Ten Siethoff, staat juister Poeloe-Madjang.

${ }^{85}$ Hunnius, Beschrijving eener reis naar de boven-Kapoeas, Geneeskundig Tijdsohrift v. Nederl. Indië, dl. X, blz. 177.

s6 Noel Denison, Jottings made during a tour amongst the Land Dyaks of Upper Sarawak, during the year 1874. Het boekje, "in private circulation only ", is alleen in hoofdstukken afgedeeld, doch niet van eene paginatuur voorzien. Ten einde de verwijzingen mogelijk te maken, hebben wij de bladzijden zelve van een doorloopend nummer voorzien.

87 Men raadplege hierbij de kaart van Noord-Borneo, behoorende bij de verhandeling van Crocker, Notes on Sarawak and Northern Borneo, Proceedings of the Royal Geographical Society, jaarg. 1881, blz. 193 vv.

88 Denison, O. o., hoofdst. IV, blz. 41.

80 De Sikajam vloeit in zuidelijke richting en stort zich rechts in de Kapoeas.

${ }^{90}$ Dit blijkt voldoende uit de beschrijving van den door Denison afgelegden weg. Zie overigens: Bakker, Het rijk Sanggau, Tijdsehr. v. Ind. T. L. en Vk., dl. XXIX, blz. 360 , en de, in noot 87 hierboven genoemde, kaart van Noord-Borneo van den Heer Crocker.

91 Korap of kurap is eene huidziekte, eene soort van ringworm. Hier is wel bepaaldelijk de ichthyosis bedoeld, die bij de Dajaks veelvuldig voorkomt. 
whole countenance a mass of small open running sores produced by small-pox, and his neck swollen to a hideous size by goitro, this man presented the appearance of a veritable messenger of evily 22 . Eindelijk zag Denison nog "some cases of goitre", in een paar dorpen aan den bovenloop van de Samarahan, eene rivier die een weinig Oostelijk van de Sarawak, en evenals deze in Noordelijke richting, naar zee vloeit ${ }^{93}$. Behalve door Denison, en geruimen tijd vó́r hem, heeft Low van het veelvuldig voorkomen van kropgezwellen onder de Land-Dajaks, bepaaldelijk in het brongebied der Sikajam, melding gemaakt. Ziehier hetgeen hij daaromtrent mededeelt: "The wens or goitres, common among the people of the hilly countries of Sumatra, are met with here amongst the tribes, inhabiting the Sangow-River ${ }^{94}$. I observed them at S'Tmpio, and am told they are much more common at Secong and Si-Panjang 85 . On account of their great size and lenght, they must be very inconvenient, though the persons afflicted with them suffer no pain from them, nor is their general health at all aflected by them. I have myself seen young women with them, so long as to hang below the breasts, and was informed that amongst other tribes they were frequently thrown over their shoulders by the people troubled with them. They appeared to me to be more frequent amongst the women than the men. I did not see them exceed more than two in number on one individual". Nog merkt Low op "that those living on the borders of the rivers, not more than 100 feet above the level of the sea, are troubled with the disease quite as much as those, the situation of whose houses is more elevated" 96 .

In de derde plaats komt Java in aanmerking. Uit het feit dat de uitstekende kenner van de zoo uitgebreide literatuur over dit eiland, de Hoogleeraar Veth, in zijn werk nergens over struma spreekt, zou men tot de conclusie moeten komen, dat de berichten daarover uiterst schaarsch zijn. Ons is het dan "ook niet gelukt, veel bijeen te brengen. Dat weinige zijn wij echter in staat nader aan te vullen met eenige gegevens, ons door de Medicinae Doctores Van der Burg, Groneman, Jacobs en Neeb, en door de Heeren De Vogel en Poensen welwillend verstrekt.

\footnotetext{
92 Denison, O. c., hoofdstuk V, blz. 50, 56 en 59.

9s Denison, O. c., hoofdstuk VII, blz. 80 .

94 De Sangow- of juister Sanggau-rivier is natuurlijk de Sikajam.

95 Dit is een van de door Denison genoemde struma-dorpen.

96 Low, Sarawak, its inhabitants and productions, blz. $306-307$.
} 
Van alle residenties op Java schijnt in Kediri struma het meest voor te komen. Het grootste gedeelte dezer residentie bestaat uit eene uitgestrekte, ran het Zuiden naar het Noorden door de KaliBrantas doorsneden, vlakte, waarin de hoofdplaats Kediri nagenoeg het middelpunt inneemt. De stad is op eene hoogte van 64 M. boven de zee gelegen. De vlakte is dus betrekkelijk laag, aan de Westen aan de Oostzijde begrensd door de vulkanen Wilis en Kloet, ten Noorden door het Middel-, ten Zuiden door het Zuider-kalkgebergte, welk laatste ook door deze residentie zijnen weg langs het Zuiderstrand voortzet, maar hier zoo laag is, dat men ter hoofdplaats nauwelijks er het profiel van aan den horizon geteekend ziet. Het land is behalve aan den kant van den Wilis en van den Kloet, waar de vlakte, langzaam oprijzende, in eene wildernis overgaat, die vooral aan de zijde van den laatstgenoemden berg een breeden, woesten gordel vormt, grootendeels van bosschen ontbloot, die voor sawahvelden en koffieaanplantingen hebben plaats gemaakt ${ }^{97}$. Op de vergadering van de "Vereeniging tot bevordering der geneeskundige wetenschappen in Nederlandsch Indië" van den 22 Maart 1883, verklaarde de Heer Idsinga in Kediri "veel struma" te hebben gezien, "ook in de vlakte" 9 s. Volgens den Heer Poensen, doet de kwaal zich meer voor bij vrouwen dan bij mannen. "Ik heb", schrijft hij mij verder, "strumueuzen zoowel in de kota als in de desa's of dukuhan's waargenomen, maar waar ik er naar informeerde, vernam ik altijd dat zij afkomstig waren uit bergachtige streken. Of de kwaal erfelijk is, weet ik niet. Ik heb vrouwen met zeer groote gezwellen gekend, wier kinderen er geen hadden, zelfs niet op huwbaren leeftijd. Voor zoover ik het heb kunnen nagaan, zijn jongelingen en meisjes er niet mede behept. De ziekte schijnt zich gedurende het huwelijk te openbaren. Ik ontmoette vrouwen op goed middelbaren leeftijd met kolossale, af hangende, als het ware, gevulde zakken. Bij anderen deed de kwaal zich voor onder den vorm van eene onevenredig groote, sterk gespannen onderkin". Ook de Heer Neeb was in Kediri herhaaldelijk in de gelegenheid, kropgezwellen te zien, niet alleen dagelijks op de hoofdplaats-zelve, vooral onder de marktbezoekers, doch ook bij vaccine-inspecties in de geheele streek Zuidwaarts tot Toelong-Agoeng. De gezwellen hadden dikwijls de grootte van een hoofd. Evenals de Heer Poensen, constateerde

97 Veth, Java, dl. III, blz. 732 vlg.

98 Geneeskundig Tijdschrift voor Nederlandsch Indië, dl. XXIV, blz. 160. 
ook Dr. Neeb meer gevallen bij vrouwen dan bij mannen, en meer bij gevorderden in leeftijd dan bij jongeren. Van herediteit is hem evenmin iets gebleken. Oostelijk van Toelong-Agoeng ligt Blitar. Ook hier komt struma voor, volgens getuigenis van den AssistentResident De Vogel. Deze noemt bepaaldelijk het dorp Panataran, Noordoostelijk van Blitar, in eene woeste, eenzame streek gelegen 9 9, als een der zetels van de endemie. Meer algemeen schijnt de kwaal in Loedåjå te zijn. Dit district, dat zich Zuidoostelijk van Blitar uitstrekt, is een der minst bevolkte gedeelten van Java. Het is schier geheel bedekt door het Zuidergebergte, waarin het water zich in den grond verliest, zoodat er geene noemenswaardige rivieren ontspringen; wel zijn er een aantal beekbeddingen, waardoor bij zware regens veel water naar de Brantas vloeit, maar als de regens ophouden, zijn zij na weinige dagen weder geheel droog. Sawah's vindt men hier in het geheel niet, droge rijstvelden alleen in de nabijheid van de Brantas; al het overige is wildernis, onder den naam van AlasLoedåjå bekend 100 . In deze Alas-Toedåjå, deze wildernis van Loedåjå, lezen wij in de "Javaansche samenspraken" van Winter, worden wong-gondok, menschen met kropgezwellen, gevonden 101 .

Niet alleen in Kediri, doch ook in de andere residenties van Oost-Java, Madioen daaronder begrepen, komen, aldus schrijft ons de Heer Poensen, kropgezwellen voor. Toch zijn zij, volgens hem, er niet zoo veelvuldig. In de uitvoerige "Geneeskundige plaatsbeschrijving van Pasaroean" van den Officier van Gezondheid Broekmeyer, lezen wij dan ook, dat van struma in deze residentie slechts "eenige gevallen" worden waargenomen ${ }^{102}$, terwijl wat Madioen betreft, van de dorpen, die daar in het Westelijke gedeelte meer of minder hoog op de ribben van den Lawoe liggen, uitdrakkelijk gezegd wordt, dat zij vrij van kroppen zijn 103 . Twee streken zijn er in Oost-Java, waar struma veelvuldiger schijnt voor te komen. In zijn werk over Bali zegt namelijk Dr. Jacobs, dat in het Těnggĕr-

\footnotetext{
99 Veth, Java, dl. III, blz. 747.

100 Veth, Java, dl. III, blz. 745-746.

101 Winter, O. c., blz. 168.
}

102 Geneeskundig Tijdschrift voor Nederlandseh Indië, dl. IV, blz. 36. - Dat in Pasoeroean weinig struma voorkomt, blijkt ook daaruit, dat noch Dr. Greiner, in zijne verhandeling "Beschouwingen over het voorkomen van krankzinnigen op de hoogvlakte van Malang" (Geneesk. Tijdschr. v. Nederl. Indië, dl. VIII, blz. 274 vlg.), noch Domis, in zijn werkje "De residentie Passoeroeang ", haar onder de domineerende ziekten en kwalen noemt.

103 Geneeskundig Tijdschrift voor Nederl Indië, dl. III, blz. 403.

5e Volgr. V. 
gebergte vele personen met deze kwaal behept zijn ${ }^{104}$. De schrijver had de goedheid mij mede te deelen, dat zijn zegsman in deze de Heer Vriesman was, als Resident van Bali en Lombok overleden. "Met dezen", schrijft hij mij, "was ik langen tijd samen, en dank ik hem vele gegevens over de Baliërs en ook het bericht over het endemisch voorkomen van struma op het Tĕnggĕr-gebergte, dat door hem in gezelschap van den Heer Hageman is bezocht". De dorpen van de zoogenaamde Tenggereezen zijn allen, gelijk bekend is, op eene aanzienlijke hoogte, verstrooid op de talrijke ribben van het gebergte, gelegen. Zoo bevindt het hoofddorp Tosari zich $1780 \mathrm{M}$. boven de zee, op eene rib, die zich tot een klein plateau verbreed heeft, terwijl rechts en links het terrein honderde voeten steil naar beneden daalt. Op ongeveer dezelfde hoogte, van gemiddeld 1800 M., zijn ook de overige dorpen gelegen, hoewel er zijn, namelijk Lidå-Ambå en Ngadisari, die tot 1972 en 1954 M. stijgen. De vegatatie is er, gelijk vanzelf spreekt, schraal, en wordt hoofdzakelijk door casuarinen gevormd 105. - De andere landstreek, door ons bedoeld, is het district Penanggoengan in Bezoeki, waar door den Assistent-Resident De Vogel, tijdens hij hier geplaatst was, meerdere gevallen van struma werden waargenomen. Dit district is het Zuidelijkste gedeelte van de vlakte van Båndåwåså, welke vlakte eene trogvormige vallei vormt tusschen het Jang- en het Ranoegebergte, ten Westen, en de Raoen met de zich hiervan in Noordoostelijke richting uitstrekkende Kendeng, ten Oosten. De vlakte, die het hoogst is aan de Zuidelijke grens, bij den zadel tusschen den Jang en den Raoen, waarvan de pashoogte 300 M. bedraagt, daalt met zachte glooiing naar het Noorden en het Noordoosten af, en is bedekt met sawahvelden, afgewisseld door koffietuinen en op hoog gezag aangelegde djatibosschen $105 \mathrm{a}$.

Van Midden- en van West-Java hebben wij weinig te zeggen. Wat Midden-Java betreft, komt, gelijk Dr. Groneman ons mededeelde, struma veel voor in Jogjåkartå, en wel op de vlakte, waaruit een deel dezer residentie bestaat. Deze, bijna geheel door sawahvelden bedekte, vlakte, die van den Merapi, in het Noorden, maar den oceaan, ten Zuiden, zacht glooiend afhelt en slechts hier en daar door heuvels afgebroken wordt, is laag ge-

\footnotetext{
104 Jacobs, Eenigen tijd ouder de Baliërs, blz. 25.

105 Veth, Java, dl. III, blz. 1008 vlg. en 1011 vlg.

$105 a$ Veth, Java, dl. III, blz. $1060 \mathrm{vlg}$.
} 
legen: de hoofdplaats Jogjåkartå, juist in het middelpunt, bevindt zich toch slechts 113 M. boven de zee 106. Struma doet zich hier vooral bij vrouwen voor, en niet alleen bij de volksklasse, doch ook bij vele personen, die tot de zoogenaamde prijaji's, de aristocratie, behooren. - In West-Java, vinden wij van Bantam vermeld, dat men "onder de bergbewoners velen met kropgezwellen vindt" 107. Welke bergbewoners hier bedoeld zijn, is moeielijk te zeggen. Het bergland bij uitnemendheid bevindt zich in het Zuidoosten der residentie, in Lebak. Volgens Blume nu treft men de kwaal, onder de hier wonende Baduwi's, somwijlen bij de vrouwen aan $10 \mathbf{7}_{\mathbf{a}}$. De Heer Van Hoëvell, die 23 jaren na Blume, in 1845, deze streken bereisde, zag integendeel onder de mannen eenige lijders $107 \mathrm{~b}$. Endemisch schijnt echter de ziekte hier niet te zijn. De Heer Kruseman kon toch slechts een enkel geval van struma constateeren, toen hij, korten tijd geleden, de Baduwi's bezocht $107 \mathrm{7}$. Verder doen zich te Batavia kropgezwellen voor. Dr. Van der Burg deelt mij namelijk mede, dat hij daar, onder de inlandsche bevolking, een groot aantal gevallen van struma gezien heeft, en wel meer bij vrouwen dan bij mannen. In hoeverre deze strumalijders van elders af komstig waren, is aan Dr. Van der Burg niet bekend. Zeker is het, dat zij te Batavia woonden. Een bewijs overigens dat struma hier kan ontstaan, vindt Dr. Van der Burg in het feit, dat hij wel eens Europeesche vrouwen, die nooit ergens anders waren geweest, met deze kwaal heeft behandeld.

Verreweg minder dan op Java, schijnt struma op Celebes, waarheen wij nu overgaan, voor te komen. Wat Zuid-Celebes betreft, schrijft Dr. Matthes mij, dat hij, voor zoover hij zich herinneren kan, nooit onder de Makassaren en Boegineezen een kropgezwel

106 Veth, Java, dl. III, blz. $610-611$ en 614.

107 Bensen, Natuur- en geneeskundige topographie der residentie Bantam, Geneeskundig Tijdschrift voor Nederlandsch Indië, dl. V, blz. 1039.

107 a Blume, Gedachten op eene reis door het Zuidoostelijk gedeelte der residentie Bantam, Indisch Magazijn, 1845, II, blz. 25.

$107 b$ Van Hoëvell, Bijdrage tot de kennis der Badoeĩnen in het Zuiden van Bantam, Tijdschr. v. Nederl. Indië, jaarg. 1845, dl. IV, blz. 370.

107e Kruseman, Eenige dagen onder de Baduwi's, Indische Gids, jaarg. 1889, dl. I, blz. 113 vlg. Opgemerkt moet hier echter worden, dat het bericht van den Heer Kruseman alleen betrekking ?heeft op de zoogenaamde djelma-dalem, die, gelijk men weet, uit veertig gezinnen moeten bestaan, terwijl Blume en Van Hoëvell over de Baduwi's in het algemeen spreken. 
heeft waargenomen. Ook Dr. Beyen, die eenige jaren als Officier van Gezondheid te Makassar doorbracht, door Dr. Matthes gehoord, verzekert evenmin strumueuzen onder de inlanders te hebben ontmoet. Anders echter de Heer Wijnmalen, die geruimen tijd als AssistentResident in de afdeeling Noorderdistricten werkzaam is geweest. Deze zag, zooals hij aan Dr. Matthes berichtte, in genoemde afdeeling vele personen met kropgezwellen. In hoeverre echter de kwaal gezegd kan worden, hier endemisch te heerschen, is uit deze enkele mededeeling bezwaarlijk op te maken. Verder Noordelijk, in het centrum van het eiland, komt struma ook voor, bepaaldelijk in het Tosigische, waar men haar toeschrijft aan het gebruik van slecht water $10 \mathbf{7 a}$. Overigens vertoont de kwaal zich, doch geheel sporadisch, in de Minahasa. Zelf heb ik, tijdens mijn verblijf in dit land, geen enkel geval kunnen constateeren. Dr. Riedel deelt mij echter mede, enkele malen, bij oude vrouwen, gezwellen te hebben geobserveerd ter grootte van een struisvogelei of van eene ontbolsterde kokosnoot. De lijderessen hielden zich meestal schuil.

Ons blijven nog de Kleine Soenda-eilanden benevens de Molukken en Nieuw-Guinea ter beschouwing over. Wat de Kleine Soendaeilanden betreft, verdient Bali in de eerste plaats genoemd te worden. Hier treffen wij weder een gebied aan, waar struma endemisch is. De Heer Van Bloemen Waanders zegt hieromtrent: "Vooral in de bergstreken ontmoet men menschen met somtijds zeer afzichtelijke kropgezwellen, en zelfs vindt men dessa's, zooals Batoe-Riti, Dahoesa en anderen, alwaar verreweg het grootste gedeelte der inwoners met zoodanige kroppen behept zijn". Bij de bewoners der laag gelegen landen is struma echter zeer zeldzaam 108. Ook de Heer Van Eck noemt struma "eene zeer algemeen voorkomende kwaal, met name onder de bergbewoners". Er zijn dorpen, gaat hij voort, "waar het grootste gedeelte der bevolking hiermede is behept. Bij sommigen hebben deze halsuitwassen eenen omvang gekregen te afschuwelijk om aan te zien" ${ }^{109}$. Uitvoeriger mededeelingen treffen wij in het werk van Dr. Jacobs aan. "Een ander feit, dat mij trof", aldus schrijft

107a Riedel, De oorspronkelijke volksstammen van Centraal Selebes, Bijdragen tot de T. L. en Vk. v. Nederl. Indië, vijfde volgreeks, dl. I, blz. 93.

108 Van Bloemen Waanders, Aanteekeningen omtrent de zeden en gebruiken der Balineezen, blz. 151-152. Zie ook het hierboven (blz. 352) geciteerde uit het "Dagverhaal eener reis over Bali" van denzelfden schrijver.

100 Van Eok, Schetsen van het eiland Bali, blz. 403 (van den overdruk). 
hij, "zijn de vele personen met kropgezwellen, die men ontmoet, en wier aantal bijna in evenredigheid staat tot de hoogte, waarop men zich bevindt, eene omstandigheid die mij ook bij mijn vroeger bezoek aan Boeleleng verraste. Zijn zij in de dessa Sangsit zeldzaam, in Bila ziet men reeds een aantal menschen, vooral vrouwen, met soms afzichtelijk groote kropgezwellen rondloopen, en dit aantal neemt gaandeweg toe, hoe meer men den top van den Soekawana nadert. In Dahoesa, doch vooral in Kintamani, is dat aantal verbazend groot, zonder overdrijving zeker de helft van de bewoners. In laatstgenoemde dessa zag ik zelfs een groot aantal nog jonge meisjes met groote kropgezwellen. In vele gevallen scheen de geheele schildklier in het proces betrokken; meestal deed de ziekte zich evenwel voor als struma lateralis sinistra. Al de gevallen, welke ik van nabij kon zien, meen ik, door de sterke uitzetting der oppervlakkig gelegen vaten der klier en die voor den onderzoekenden vinger toegankelijk waren, te mogen rangschikken onder den vorm, die door Ecker als struma vasculosa wordt beschreven, in tegenstelling van de struma glandulosa, die meer de verdikking van het klierweefsel-zelf betreft. Vrouwen •zijn meer aan de ziekte onderhevig dan mannen". Ten aanzien van de erfelijkheid van de struma merkt Dr. Jacobs op, dat een onderzoek daarnaar, onder eene bevolking waarvan de helft aan de kwaal lijdt, weinig uitkomsten heeft kunnen opleveren 110 . Wat de zooeven genoemde plaatsen betreft, zij in het algemeen nog opgemerkt, dat Sangsit in de kustvlakte, ten Noordootsen van Boeleleng, en Dahoesa en Kintamani op het Batoer-gebergte, bij den top Soekawana, gelegen zijn, Dahoesa op een smallen rug, ter hoogte van 1280 M. 111. Het, door Van Bloemen Waanders genoemde, dorp Batoe-Riti bevindt zich in Tabanan, ten Zuiden van het meer Baratan, ongeveer $900 \mathrm{M}$. boven de zee 112 .

Van de overige Kleine Soenda-eilanden hebben wij nog Timor te noemen. Forbes, die de binnenlanden van het aan Portugal behoorende gedeelte bezocht, vond kropgezwellen in het district Saloeki. "This", schrijft hij van zijn verblijf alhier, "was the first metalliferous district I had visited, and for the first time the proportion of the people suffering from goitre was so large as to attract notice from

110 Jacobs, Eenigen tijd onder de Baliërs, blz. 20 en 23.

111 Zollinger, Togt naar het gebergte Bator, Bijdragen tot de T. L. en Vk. v. Nederl. Indië, derde volgreeks, dl. I, blz. 507.

112 Dagverhaal eener reis over Bali in Juni en Juli 1856, Tijdschrift v. Nederl. Indië, jaarg. 1870 , dl. I, blz. 420 . 
the most casual observer" 113. In het Nederlandsche, dat is het Zuidwestelijke, gedeelte van Timor, schịnt struma niet voor te komen: Dr. Riedel zag, gelijk hij mij mededeelde, hier geen enkelen kroppatient. Daarentegen ontmoette hij te Doelolong, op Alor, eene vrouw van middelbaren leeftijd met eenen krop, volgens zeggen als gevolg van een moeielijken partus, terwijl te Masara, op Sawoe, eene jonge, ongehuwde dochter van een der radja's ook aan struma leed. Overigens doet de kwaal zich op beide eilanden uiterst spo. radisch voor.

Wat de Molukken betreft, is het alleen van Boeroe dat wij iets omtrent struma medegedeeld vinden. Zelf heb ik, tijdens mijn verblijf op dit eiland, geen lijder gezien. Volgens Dr. Riedel echter "komen kropgezwellen nu en dan voor, en worden zijj toegeschreven aan het veelvuldig beklimmen van bergen" 114. Ook omtrent NieuwGuinea hebben wij slechts een enkel bericht. De Heer Von Rosenberg deelt namelijk mede, dat vele der bergbewoners van Hattam, bij de Dorei-baai, aan kropgezwellen lijden $\mathbf{1 1 5}$.

Uit het hiervoren medegedeelde, zien wij hoe struma endemisch zich voordoet op Sumatra en Borneo, verder op Java, doch in mindere mate, en meer in de Oostelijke dan in de Westelijke helft, in Centraal-Celebes, op Bali, in Portugeesch Timor en in Noordwestelijk Nieuw-Guinea. Op de overige eilanden van den Archipel kan struma, hoewel hier en daar voorkomende, niet gezegd worden, endemisch te heerschen.

Het gebied van de endemische kropgezwellen is niet zelden van groote uitgestrektheid. Vooral op Sumatra is dit het geval. Zoo is in de Westelijke helft van de landstreek, die door de Moesi met hare uitgebreide zijtakken en door de Toelang-Bawang en de Sipoetih bespoeld wordt, struma eene algemeene kwaal. Niet minder uitgestrekt is het gebied van de endemische kropgezwellen in MiddenSumatra, dat zich van de keten Goenoeng-Patah-Sembilan, GoenoengKorintji en Goenoeng-Toedjoeh, ten Zuiden, tot Bondjol, ten Noorden, uitstrekkende, de bovenlanden van de Batang-Hari, de BatangKoeantan of rivier van Indragiri en de Kampar-Kanan omvat. Wat Noord-Sumatra betreft, is struma eene endemische ziekte in Mandaï-

\footnotetext{
113 Forbes, A naturalist's wanderings in the Eastern Archipelago, blz. 468.

114 Riedel, De sluik- en kroesharige rassen tusschen Selebes en Papua, blz. 27.

115 Von Rosenberg, Reistochten naar de Geelvinkbaai, blz. 104.
} 
ling en in het bovenstroomgebied van de Pane en de Bila. Kleinere landstreken met endemische struma zijn overigens Serampei, in Zuid-, de Petalangan, in Midden-, en de binnenlanden van Deli en Serdang, in Noord-Sumatra. Ook op Borneo vindt men een uitgestrekt gebied van endemische kropgezwellen. Als zoodanig toch is het geheele Oostelijke gedeelte van de benedenlanden van de Barito, dat zijn de landen van de Patai en de Karau, de Negara- en de Martapoera-rivieren, met Tanah-Laoet, te beschouwen. In de WesterAfdeeling, in het stroomgebied van de Kapoeas, zijn het een tweetal landstreken, het brongebied van de Sikajam en het land, waardoor de Melawi stroomt, waar struma endemisch voorkomt. Op Java is Kediri een strumagebied, en evenzoo Jogjåkartå, terwijl er nog enkele kleinere streken zijn, waar de kwaal zich voordoet. Wat Celebes aangaat, is het slechts van een enkel, en ook weinig omvangrijk district, in het centrale gedeelte, dat ons het voorkomen van struma medegedeeld wordt. Evenzoo is op Bali, in Portugeesch Timor en op Nieuw-Guinea het gebied van de endemische struma niet zeer uitgestrekt.

Het behoeft nauwelijks gezegd te worden, dat er in al de hier genoemde streken gedeelten zijn, waar de kwaal weinig voorkomt of geheel ontbreekt. Overal en altijd zijn het binnen een gebied van endemische struma, hoe groot of klein dit ook zij, om met Hirsch te spreken, "nur einzelne, oft eng umschriebene Punkte, einzelne Ortschaften, welche den Sitz der Endemie abgeben und über welche hinaus selbst schon in der allernächsten Nachbarschaft vollkommene Immunität besteht" 116. Dat dit ook in den Indischen Archipel het geval is, kan uit het hierboven medegedeelde gebleken zijn. Zoo is, om hier slechts een paar van de meest karakteristieke voorbeelden in herinnering te brengen, in het landschap waardoor de Djoedjoean stroomt, behoorende tot het strumagebied van Midden-Sumatra, het dorp Tandjoeng-Alam een der zetels van de endemie. In RantauIkir evenwel, een weinig benedenstrooms aan dezelfde rivier gelegen, doet zich de kwaal in het geheel niet voor 117. Zoo bestaat in Redjang-Ampat-Petoelai, in het strumagebied van Zuid-Sumatra, in de dorpen langs de Moesi en de Ajer-Poetih volkomene immuniteit, terwijl overigens in het geheele district struma eene algemeene kwaal is 118 .

116 Hirsch, Handbuch der historisch-geographischen Pathologie, dl. II, blz. 111. 117 Zie blz. $360-361$ hierboven.

118 Zie blz. 350-351 hierboven. 
Evenals elders, zien wij hoe ook in den Indischen Archipel de kropgezwellen "in ihrem endemischen Vorkommen von Elevation und Configuration des Bodens im Allgemeinen allerdings unabhängig sind" 119. Nemen wij bij voorbeeld Sumatra. Struma wordt hier aangetroffen zoowel in de lage, vlakke of heuvelachtige streken, op plaatsen, die meestal nog geen $100 \mathrm{M}$. boven de zee zich bevinden, als in het centrale bergland, waar de zetels der endemie eene hoogte van 400 tot $1000 \mathrm{M}$. bereiken ${ }^{120}$. Hier, in het centrale bergland, nemen wij ook ten aanzien van de terreinformatie de grootste verscheidenheid waar. De strumadistricten bestaan uit omvangrijke en open plateaux, uitgestrekte en breede dalen, nauwe, diepe en ingesloten valleien en dalketels. Niet minder duidelijk zien wij op Borneo en op Bali, hoezeer het voorkomen van struma van de hoogte en bodemvorming geheel onafhankelijk is. Op Borneo, hoewel de kwaal zich hier ook in het gebergte voordoet, behooren de voornaamste streken van de endemische kropgezwellen tot de lage heuvellanden, op Bali daarentegen uitsluitend tot het hooggebergte, 900 tot $1200 \mathrm{M}$. boven de zee. Heet het van dit eiland, dat de ziekte toeneemt hoe hooger men stijgt 121, van Borneo wordt verzekerd, dat "those living on the borders of the rivers, not more than 100 feet above the level of the sea, are troubled with the disease quite as much as those, the situation of whose houses is more elevated" 122 . Eene even groote verscheidenheid vertoonen de strumadistricten op Java. Men vindt de kwaal zoowel op eene hoogte van 1800 M. op de ribben van den Tĕnggër, als op middelmatig verheven plateaux en op laagvlakten, die nog geen 100 M. of slechts weinig meer boven de zee

119 Hirseh, Handbuch der historisch-geographischen Pathologie, dl. II, blz. 112.

120 Eenige strumadistricten in het centrale bergland liggen echter lager dan $400 \mathrm{M}$. Zoo Mahi en Kapoer-nan-sembilan, waarvan de hoogte respectievelijk 250 en gemiddeld $110 \mathrm{M}$. bedraagt. Het land, waarin deze beide districten gelegen zijn, is, gelijk wij hierboven (blz. 362-363) gezien hebben, een plateau, zeer geaccidenteerd, afgebroken door diepe en nauwe kloven en door bergen, die aan eene of meer zijden loodrechte wanden bezitten. Volgens Dr. Verbeek, zijn deze bergen opgeheven stukken, gedeelten van het versoheurde terrein, die in verticale richting veel meer werden verplaatst dan de aangrenzende deelen, terwijl de kloven scheuren zijn bij de opheffing ontstaan en later dour erosie verbreid en uitgediept. Zulke, ten oprichte van het omliggende land, minder opgeheven gedeelten van den bodem zijn ook de districten Mahi en Kapoer-nan-semhilan (Verbeek, Topographische en geologische besohrijving van een gedeelte van Sumatra's Westkust, blz. 628 vlg.).

191 Zie blz. 378 vgl. hierboven.

192 Zie blz. 373 hierboven. 
zich uitstrekken. Zelfs van kustplaatsen, immers van Batavia, wordt het voorkomen van kropgezwellen vermeld. Intusschen is het, bij eene zoo vlottende bevolking als deze stad heeft, zeer wel mogelijk, dat de door. onzen berichtgever, Dr. Van der Burg, waargenomen lijders van elders herkomstig waren. Het zou althans voorbarig zijn, de kwaal hier als endemisch te beschouwen, te meer daar men haar tot dusverre nergens in de nabijheid van de zee heeft aangetroffen. "Es existirt", zegt Hirsch, "in der ganzen Literatur in der That nicht eine Andeutung, dass diese Krankheit jemals endemisch in einem Küstenlande geherrscht habe oder noch herrsche"1 $\mathbf{1 2 3}^{\mathbf{3}}$.

Niet overal komt de kwaal in gelijke mate voor. Volgens Dr. Jacobs, zijn in de bergstreken van Bali, in sommige dorpen, 50 pCt. van de inwoners met kroppen behept. In Makakau, in het strumagebied van Zuid-Sumatra, zou, volgens twee verschillende berichtgevers, het aantal lijders 70 en 80 pCt. bedragen. Veel geringer is het cijfer van de strumueuzen in de, tot hetzelfde strumagebied behoorende, landschappen Belalau en Redjang-Ampat-Lawang, namelijk 20 pCt. en het zesde deel der bevolking of $16^{2} / 3$ pCt. Van de overige streken van dit strumagebied ontbreken numerieke opgaven. Uit de bewoordingen van de verschillende berichtgevers blijkt echter voldoende, dat het aantal lijders dikwijls zeer aanzienlijk is. Zoo heet het van de Redjang-Ampat-Petoelai, dat struma daar "eene algemeene kwaal" is. Een ander spreekt van het "overgroot antal" personen, die in dit district met kroppen behept zijn. In Pasemah en in het gebied van de Wai-Ompoe moet het procentcijfer der lijders zeker zeer hoog zijn, daar van het eerstgenoemde landschap gezegd wordt, dat "almost every individual is affected with goitre", terwijl het bericht omtrent de Wai-Ompoe luidt, dat "de meeste menschen" daar struma hebben. Evenmin hebben wij numerieke opgaven omtrent het strumagebied van Midden- en van Noord-Sumatra. Wat het gebied van Midden-Sumatra betreft', is wel het Zuidelijkste gedeelte daarvan, dat is Soepajang, Alahan-Pandjang, Lolo en Soengei-Pagoe benevens de landstreek waardoor de Djoedjoean stroomt, het zwaarst bezocht. - Op Borneo schijnt in het strumagebied van de Beneden-

123 Hirsoh, Handbuch der historisch-geographischen Pathologie, dl. II, blz 429-430 (van den eersten druk). Zie blz. 112 (van den tweeden druk). "Am bemerkenswerthesten", lezen wij hier (noot 5), "ist dieser Umstand in denjenigen Ländern, wo der Kropf in den den Bergabhängen sich anschliessenden Tiefebenen in weiter Verbreitung herrscht, die eigentlichen Küstenstriche aber vollkımmen frei lässt, wie u. a. in Brasilien". 
Barito, en hier weder bepaaldelijk in Tanah-Laoet, de meeste lijders voor te komen, waar, althans te Habalang, van de tien personen acht, dus 80 pCt. van de geheele bevolking, kroppen bezitten. Overigens heeft, gelijk wij hierboven opmerkten 124, de mededeeling van den Deenschen natuuronderzoeker Bock, dat van de drie Dajaksche vrouwen ééne een gezwel heeft, misschien ook op he strumagebied van de Beneden-Barito betrekking. - Verreweg nninder algemeen is zeker de kwaal op Java, zelfs waar zij het meest op dit eiland endemisch is, namelijk in Kediri. Intusschen is wellicht te vaak uit het oog verloren, dat, bij het karakteristiek gebonden zijn van de struma aan bepaalde, dikwijls weinig uitgestrekte streken, men het procentcijfer der lijders niet berekenen moet naar de geheele massa der bevolking, van bij voorbeeld eene residentie, eene afdeeling of een district, doch uitsluitend naar het zielental der platsen, die de zetels der endemie zijn.

Het is van genoegzame bekendheid, dat struma tot de kwalen behoort, die zich meer bij mannen dan bij vrouwen voordoen. Ook in den Indischen Archipel vinden wij dit bevestigd. De meeste berichtgevers vermelden uitdrukkelijk, dat meer vrouwen dan mannen met kropgezwellen behept zijn. In eene enkele mededeeling wordt het tegenovergestelde beweerd. In Batipoe en de X Kota zou men, volgens den Officier van Gezondheid Kervel, meer mannen dan vrouwen met struma zien ${ }^{125}$. - Omtrent het tijdstip, waarop de gezwellen zich beginnen te ontwikkelen, vinden wij weinig vermeld. Enkele opgaven schijnen er op te wijzen, dat dit bij het einde der kindsheid of bij het intreden der puberteit geschiedt 126 . Soms evenwel openbaart de kwaal zich eerst op lateren leeftijd, bij voorbeeld bij vrouwen, die meermalen gebaard hebben. In allen gevalle zijn het - vele mededeelingen komen hierin overeen - vooral volwassenen en zelfs meer gevorderden in leeftijd, die aan kropgezwellen lijden. - Van het voorkomen van 'struma cougenita wordt nergens gewag gemaakt. Niet onwaarschijnlijk is het echter, dat de kwaal, waar zij zich bij kleine kinderen vertoont, van 4 à 5 of 7 à 8 jaren, gelijk Neumann bị de Bataks, Forbes bij de bewoners van Belalau zag, als aangeboren moet worden beschouwd. Herediteit

\footnotetext{
124 Zie blz. 370 vlg.

125 Zie blz. 361 hierboven.

126 Men houde hierbij in het oog dat de puberteit in de tropische landen vroeger intreedt dan in de gematigde luchtstreken, bij meisjes bij voorbeeld reeds op twaalf- tot veertienjarigen leeftijd.
} 
zou, volgens den inlander, naar de mededeelingen van enkele berichtgevers, bestaan 126a. Opzettelijke onderzoekingen daarnaar schijnen echter weinig te zijn ingesteld of geene resultaten te hebben opgeleverd. Alleen wordt door Dr. Wyckerheld Bisdom opgemerkt, dat, in de weinige gevallen dat hij zulk een onderzoek heeft kunnen doen, het hem gebleken is, dat overerving eigenaardigerwijze uitsluitend in de vrouwelijke lijn plaats heeft.

Over de vormen waarin de gezwellen zich plegen voor te doen, zwijgen de meeste berichtgevers. Dr. Jacobs - een der weinigen die daarover spreken - constateerde in de meeste gevallen struma lateralis sinistra. Daarentegen vond Dr. Wyckerheld Bisdom de zitplaats van het gezwel vaker rechts dan links, doch meestal in het midden of aan beide zijden. Ook Hastings Dare spreekt van "two protuberances", en zagen wij in de Harangan-Sipirok eveneens dezen vorm van struma, welke vorm blijkbaar mede door de Heeren Van Rees en De Rooy bedoeld wordt, als zij van de gezwellen zeggen, de een, dat zij den lijders soms als een ring om den geheelen hals zitten, de ander, dat zij er uitzien als twee sterk gezwollen en aan elkaar gegroeide blazen 127. De vorm, vinden wij verder opgegeven, is meestal gelapt, soms knollig, enkele malen glad omschreven. De consistentie is afwisselend van week tot zeer hard. Overigens vertoonen de strumae zich van af eene nauw merkbare zwelling tot uitwassen, die zoo vooruitsteken, dat het gelaat geheel daarachter wegvalt, of die als een gevulde buidel naar beneden hangen. De grootte is die van een papaja, een pompelmoes, eene van den bast ontdane kokosnoot, een struisvogelei of een kinderhoofd. Soms bereiken de gezwellen zulk eenen omvang, dat zij, bij het loopen, met de handen gesteund of zelfs - incredibile dictu! over de schouders geworpen moeten worden. Pijn of ongemak, aldus verklaren eenige berichtgevers, veroorzaken de strumae niet, en de algemeene gezondheidstoestand wordt er niet door aangedaan: de aangetasten zijn even opgewekt en vroolijk als de gezonden 128 .

126a Zie hierover nog blz. 421 hierbeneden.

197 Zie ook: Ethnographische Atlas van Midden-Sumatra, Pl. VI, fig. 2, waar een persoon uit de Zuidelijke Padangsche Bovenlanden afgebeeld is met een kropgezwel ter weerszijden van den hals, doch aan den linkerkant iets meer ontwikkeld dan aan den rechter.

128 Een geregeld onderzoek naar de hartwerking bij strumueuzen schijnt weinig te hebben plaats gehad. Alleen bij Dr. Wyckerheld Bisdom vinden wij iets daaromtrent vermeld. Afwijkingen van het hart constateerde deze bij 89 van de 219 door hem daarop onderzochte strumalijders, namelijk: bij 15 onregelmatige hart- 
Toch is het aan te nemen, dat de eenigszins groote gezwellen den lijders lastig zullen zijn. De Heer Neumann zegt dan ook, dat dergelijke strumalijders zeer te beklagen zijn, dat zij moeielijk zwaren arbeid verrichten of moeielijke en langdurige tochten makes kunnen. De ademhaling is gewoonlijk zwaar en gaat in den slaap nog gepaard met eene soort van blaffen en andere onwelluidende klanken. In het stervensuur is hun de drukking op de ademhalingswerktuigen zelfs zeer smartelijk. - Dat de, tot volle ontwikkeling gekomen, uitwassen het voorkomen van den inlander in hooge mate ontsieren, wordt herhaaldelijk gezegd: zij maken het uiterlijk afzichtelijk, is het oordeel van den Heer Van Hasselt, geven aan het gelaat iets walgelijks, bijna iets dierlijks, zegt de Heer Schouw Santvoort. Hierbij komt dat de stem bij strumalijders een onaangenamen klank heeft: het is, merkt laatstgenoemde berichtgever op, een eigenaardig schor en diep keelgeluid, dat zij doen hooren. Volgens den Heer Neumann, wordt het geluid gedeeltelijk door den neus voortgebracht.

II.

Kortelijk wenschen wij in dit hoofdstuk de verbreiding van de struma in den Indischen Archipel na te gaan, in verband met eenige momenten, die als aetiologische plegen beschouwd te worden.

Als een bij uitstek endemische ziekte, ligt het voor de hand de oorzaak der kwaal in de eerste plaats in tellurische en atmospherische invloeden te zoeken. . Dat echter het voorkomen van de struma noch van de hoogte, noch van de terreinformatie afhankelijk is, hebben wij zooeven reeds doen uitkomen 129 . Evenmin is het dit van de atmospherische gesteldheid. In de streken van den Indischen Archipel, waar struma endemisch heerscht; treft men de meest uiteenloopende klimatologische toestanden aan. Anders, om bij voorbeeld het strumagebied van Zuid-Sumatra te nemen, het klimaat van de open en betrekkelijk weinig begroeide hoogvlakten van Belalau, Makakau en Pasemah, anders dat van de lage heuvelachtige, met dichte bosschen bedekte, landen door de

werking, bij 25 palpitationes cordis, bij 3 hypertrophia ventriculi sinistri, bij 3 andere id. ventr. dextri, bij 17 langzame en zwakke hartwerking, bij 18 insufficientia valvulae mitralis, bij 7 id. valvulae aortae, bij 1 stenosis ostii ventriculi sinistri (Wyckerheld Bisdom, Een en ander bij struma, Genesskundig Tijdschrift v. Nederl. Indië, dl. XXIX, blz. 527).

199 Zie blz. 382 vgl. hierboven. 
Toelang-Bawang en de Sipoetih doorstroomd: hier is het vochtig en heet, als gevolg van de weinig vrije doorstrooming van den dampkring, daar, bij eene drogere lucht, frisch, ja zelfs koud of guur. Doch het kan onnoodig zijn, dit met meer voorbeelden nader toe te lichten. Alleen wenschen wij nog eenige opmerkingen te maken naar aanleiding van de meermalen geuite meening, dat "starke Luftfeuchtigkeit in Verbindung mit relativ hoher Temperatur und mangelhafter Beleuchtung und Ventilation", ten gevolge van de terreinvorming of van eene uiterst weelderige vegetatie, voor de ontwikkeling der kwaal bijzonder gunstig zou zijn. De onderzoekingen van Hirsch hebben doen zien, dat voor deze meening weinig grond is $\mathbf{1 8 0}$. Ook in den Indischen Archipel wordt zij door de waarneming niet bevestigd. Zeker zijn er hier streken, zetels van de endemie, waar evenbedoelde atmospherische verhoudingen zich voordoen. Wij noemden daar juist de lage landen van het strumagebied van Zuid-Sumatra. Doch tegenover deze stelden wij reeds de hooggelegen plateaux van hetzelfde strumagebied, waar geheel andere toestanden worden aangetroffen. Overigens kunnen wij hier nog op Borneo en Java wijzen. Op het eerstgenoemde eiland zien wij, hoe, in de voornaamste strumadistricten, het terrein open en voor den wind toegankelijk is, terwijl geen weelderige plantengroei de vrije doorstrooming van de lucht in den weg staat. Zoo op de vlakten en in de heuvellanden van Tanah-Jaoet, Margasari en Benoewa-Ampat en van Doesoen-Timor, die immers 131 over groote uitgestrektheden met alang-alang-velden bedekt of slechts met laag kreupelhout bewassen zijn. In verband hiermede is het klimaat er zeer afwisselend. Overdag heerscht er, zegt Schwaner, meer bepaaldelijk van Doesoen-Timor, vooral in den drogen tijd eene zeer hooge temperatuur, welke voornamelijk op de djowong's, de plateauvormige heuvelruggen, ondragelijk is. De grond is dan zoo doorgloeid, dat de inboorling dien slechts met dikke, uit boomschors gemaakte, sandalen durft betreden. Gedurende den nacht daarentegen valt er een sterke dauw, en tegen den ochtend is het er doordringend koud, niet zelden in die mate, dat men genoodzaakt is tot verwarming groote vuren aan te leggen 132 . Wat Java betreft, komt, gelijk wij gezien hebben, struma hier meer in de Oostelijke dan in de Westelijke helft voor, in het ge-

\footnotetext{
130 Hirsch, Handbuch der historisoh-geographischen Pathologie, dl. II, blz. 123 vlg. 131 Zie blz. 367,368 en 369 hierboven.

132 Schwaner, Borneo, dl. I, blz. 97.
} 
deelte dus, dat, zooals van genoegzame bekendheid is, verreweg het droogste klimaat heeft. Het Oosten is bovendien het land der weinig dichte casuarinen-bosschen, die voor de vrije en geregelde doorstrooming van de lucht zeker minder een hinderpaal zijn dan de vochtige, donkere en schaduwrijke loofwouden, welke zich in het Westen over geheele landstreken uitbreiden. Beschouwen wij nu in het bijzonder de vlakte van Kediri, waar meer dan elders op het eiland struma endemisch heerscht. Het klimaat is er heet en droog, doch over het algemeen gezond, gezonder althans dan in die gedeelten van het eiland, welke langs het zeestrand gelegen zijn, en waar hitte en vochtigheid steeds met elkander hand aan hand gaan. Aan eene vrije doorstrooming van de lucht ontbreekt het hier ook niet: de vlakte is toch - wij wezen er hierboven reeds op ${ }^{133}$ - naar het Zuiden open, immers door een zeer laag gebergte begrensd, terwijl - hetgeen wij boven mede hebben opgemerkt - de bosschen er grootendeels uitgeroeid en in rijstvelden en aanplantingen van koffie herschapen zijn, zoodat niets den wind tegenhoudt, die vooral bij helder weder, bijna zonder tusschenpoozen, van den kant van den Indischen Oceaan over het land waait ${ }^{134}$. Eindelijk is Timor daar, om te bewijzen, dat in goed geventileerde streken - ook op dit eiland toch mist men de donkere en dichte bosschen, en vormen de casuarinen en de eucalypti eene armelijke vegetatie - met een bij uitstek droog klimaat, struma evengoed zich tot eene endemische ziekte ontwikkelen kan als op plaatsen met geheel tegenovergestelde atmospherische verhoudingen.

Noch uit de hoogte, noch uit de configuratie van den bodem, noch uit de atmospherische gesteldheid is de endemische struma te verklaren. "Ein besonderes Interesse", aldus Hirsch, "bietet die Frage, ob zwischen dem geologischen, bez. mineralogischen Character des Bodens und dem endemischen Vorherrschen von Kropf nachweisbar ein Zusammenhang besteht - eine Frage, welche fast alle neueren Beobachter mehr oder weniger lebhaft beschäftigt hat"135. Ook wij wenschen dit voor den Indischen Archipel na te gaan. Aangezien, gelijk straks zal blijken, men in de aanwezigheid van kalk-

133 Zie blz. 374.

134 Veth, Java, dl. III, blz. 733. Zie ook: Junghuhn, Java, dl. III, blz. 627 vlg.

185 Hirsch, Handbuch der historiseh-geographischen Pathologie, dl. II, blz. 114. 
gesteenten in den bodem in het bijzonder een aetiologisch moment heeft willen zien, zal daarbij in de eerste plaats op het voorkomen van deze gesteenten gelet worden.

Beginnen wij met Sumatra $135_{\mathrm{a}}$. De oudste gesteenten van dit eiland, die grootendeels de kern van het centrale bergland, den Boekit-Barisan, uitmaken, zijn de zoogenaamde "oude leien", welke in vele gevallen in verbinding met oude eruptieve gesteenten van de groep der granieten optreden. Van de leien kan, daar er tot dusverre geene versteeningen in gevonden zijn, de ouderdom niet met zekerheid bepaald worden. Dat zij zich echter gevormd hebben in eenen tijd, die aan de steenkolenperiode voorafging, en dus devonisch dan wel silurisch zijn, wordt door Dr. Verbeek en anderen aangenomen ${ }^{135} \mathrm{~b}$. De granieten zijn zeker, waar zij gangen in de leien vormen, jonger dan deze, doch is het vooralsnog niet met zekerheid te zeggen, in hoeverre dit met allen het geval is. Voor een groot deel zijn deze oude gesteenten aan de oppervlakte niet meer zichtbaar, doch door jongere vormingen bedekt. Tot de sedimentaire behooren afzettingen van den carbonischen tijd en tertiaire lagen. Vooral deze laatsten zijn sterk ontwikkeld. Hoofdzakelijk zijn zij door het eoceen vertegenwoordigd, dat in vier etages voorkomt. Doch ook het mioceen en het plioceen worden, hoewel in mindere mate, eveneens op Sumatra gevonden 1850. Naast deze sedimentaire formaties, heeft men nog eenige groepen van eruptieve gesteenten. Allereerst de diabazen, die tamelijk uitgestrekte bergterreinen vormen en jonger dan carbonisch schijnen te zijn. Verder moeten, na afzetting van het jongste lid der eoceene vorming, op Sumatra, evenals elders in den Archipel, uitgestrekte erupties van andesieten, voornamelijk augiet-andesieten, hebben plaats gehad, welke zelfstandige heuvels en heuvelreeksen, zonder krater en zonder kegelvorm, deden ontstaan. Deze andesieten worden "oudere andesieten" genoemd, in tegenstelling van de andesieten, voornamelijk weder augiet-andesieten, die te zamen met bazalt, gedeeltelijk in stroomen, gedeeltelijk in losse blokken of in uiterst kleine stukjes

$135 a$ Voor een algemeen overzicht van de geologie van Sumatra, zie: Martin, Die wichtigsten Daten unserer geologischen Kenntniss vom Niederländisch Ost-Indischen Archipel, Bijdragen tot de Taal- Land- en Volkenkunde van Nederlandsch Indië, uitgegeven ter gelegenheid van het Orientalisten Congres te Leiden, blz. 18 vlg.

$135 b$ Zie intusschen noot 141 en 155 hierbeneden.

135c Over de afwijkende meeningen ten aanzien van de ouderdomsbepaling van de tertiaire gesteenten van Sumatra, zie noot 141 hierbeneden. 
en in poedervorm, als zand en asch dus, het materiaal samenstellen, waaruit de tegenwoordig bestaande, werkzame of uitgedoofde, vulkanen zijn opgebouwd. Het begin van de vorming dezer vulkanen valt in den post-tertiairen, dus in den kwartairen, tijd. Voor het grootste gedeelte bestaan ook de kwartaire sedimenten van Sumatra, het diluvium, hoewel hier en daar de oudere gesteenten aan de samenstelling daarvan hebben deelgenomen, uit dit jong vulkanisch materiaal, dat in de zee, in binnenmeren en langs de rivieren werd afgezet.

Wij zullen nu, na deze algemeene opmerkingen, die wij, tot recht verstand van het volgende, gemeend hebben, voorop te moeten stellen, trachten de geologische gesteldheid van de voornaamste strumadistricten na te gaan.

In het strumagebied van Zuid-Sumatra is de bodem hoofdzakelijk uit vulkanische gesteenten en vulkanisch diluvium gevormd 136. De vulkanische gesteenten, augiet-andesieten en basalt, worden gevonden in het centrale bergland. Ook het vulkanisch diluvium komt in het centrale bergland voor, namelijk als meerdiluvium in Belalau, Makakau en Redjang-Ampat-Lawang, doah wardt sverigerss als zeediluvium in de lage landen aangetroffen 137. Het meerdiluvium bestaat uit echte puimsteentuffen, het zeediluvium uit eene bruine klei, die, hoewel hoofdzakelijk een verweringsproduct van vulkanische

130 Zie voor het volgende: Topographische en geologische beschrijving van ZuidSumatra, Jaarboek van het Mijnwezen in Nederlandsch Oost-Indië, jaarg 1881, dl. I, en de daarbij behoorende geologische kaart in 4 bladen.

137 Het zeediluvium gaat gewoonlijk de $100 \mathrm{M}$. niet te boven en bereikt slechts zelden eene hoogte van 200 M. Daarentegen is het meerdiluvium van Belalau 900 M. , dat van Makakau 250 tot 700 M., dat van Redjang-Ampat-Lawang 300 tot 400 M. hoog (Verbeek, O. c., blz. 205-207). Het is niet waarschijnlijk, zegt Verbeek (blz. 207 vlg.), dat de zee in den diluvialen tijd zioh nog tot deze streken uitstrekte; men zoude dan eene opheffing van ruim 900 M. in een post-diluvialen tijd moeten aannemen, en de diluviale zeeafzettingen zoude men op veel punten hooger moeten aantreffen, dan nu het geval is. Evenmin heeft men hier met luchtsedimenten te doen, daar de afzetting in lagen daarvoor veel te regelmatig is. Het waarschijnlijkste is dus, dat de vulkanisehe stoffen in binnenmeren werden afgezet, die later droog gelegd werden. Opgemerkt moet echter worden, dat de mogelijkheid van eene opheffing, als door Dr. Verbeek bedoeld, niet geheel is uitgesloten. Ten aanzien van de vulkanische zeesedimenten van Java heeft toch Guppy nog kortelings kunnen constateeren, dat "the upheaval in post-tertiary times has been very great, and can only be measured by several thousands of feet " (Guppy, Preliminary note on the geological structure of the Sindang-Barang district, on the South Coast of Java, Scottish Geographical Magazine, jaarg. 1889 , blz. 76). 
stoflen, vooral in de nabijheid van den Barisan, rolstukken van oudere andesieten, granietgesteenten en leisteenen bevat. In het stroomgebied van de Toelang-Bawang vindt men bovendien, langs de oevers van de Wai-Ompoe, tusschen de dorpen Blambangan en Pakoean, zeer fijne, zachte, witte of lichtgrijze tuffen van eene kleiachtige of kaolienachtige hoedanigheid, met vrij talrijke puimsteenbrokstukken vermengd, waardoor de oorsprong van deze tuffen duidelijk wordt. - Behalve deze jongere vulkanische gesteenten en vulkanische sedimenten, vindt men in het strumagebied van ZuidSumatra nog enkele oudere vormingen. Zoo is in Rawas, ten Westen van het vulkanisch zeediluvium, waaruit ook de lage landen dezer onderafdeeling bestaat, tusschen de dorpen Loeboeq-Mas en Napal. Jitjin, een terrein gelegen van oude leien, bepaaldellijk dunschilferige lichtgrijze kleileien, met kwartsgangen, hier en daar, van geringe dikte. Oude leien, hoofdzakelijk weder kleileien, worden verder gevonden, in vereeniging met diorieten, aan de Westzijde van het plateau, waartoe Makakau behoort, terwijl aan de Oostzijde van dit plateau eene granitietreeks zich uitstrekt. Elders nemen de oudere, oud-mioceene, augiet-andesieten een voornaam deel in de samenstelling van den bodem, gelijk onder anderen in den Boekit-Barisan, ten Noordwesten van den Dempo, en in de daarmede evenwijdig loopende keten, waardoor de Redjang-landen ingesloten worden. - Ook de tertiaire vormingen - de gesteenten van de kolenperiode ontbreken geheel in Zuid-Sumatra - komen hier en daar te voorschijn uit hare bedekking van vulkanische gesteenten en vulkanische sedimenten. Tot deze vormingen behoort in de eerste plaats het eoceen. Zoo bestaat, in het gebied van de Sipoetih-rivier, het vlakke land uit vulkanisch zeediluvium, het heuvelland daarentegen uit betrekkelijk zeer vaste zandsteenen en conglomeraten van de eerste of oudste etage van het eoceen, die blijkbaar opgebouwd zijn uit het materiaal van het granitiet, dat de onderlaag dezer formatie uitmaakt. Doch merkwaardiger is het voorkomen van kalksteenen, die samen met mergels en mergelkalk, de vierde of jongste etage van het eoceen vormen. Voornamelijk treft men deze gesteenten in Makakau aan, grootendeels echter bedekt door de puimsteentuffen, waaruit dit plateau bestaat, zoodat zij alleen waar te nemen zijn in de beddingen van de rivieren, met name van de Sako, met hare zijtakken de Kemoe en de Keni, en van de Selaboeng. In de Sako bij voorbeeld kan men van Moeara-Doea, hoofdplaats van de onderafdeeling Komering-Oeloe, stroomopwaarts den kalksteen vervolgen 5e Volgr. V. 
tot boven de doesoen Saoeng-Naga, in de nabijheid van welke plaats de Keni in het gesteente een onderaardschen loop heeft en eene grot heeft uitgespoeld. Verder is, in de bedding van de Sako, nog kalk te zien tusschen de dorpen Blambangan en Soera, terwijl langs de Selaboeng de lagen zijn waar te nemen tot bij de doesoen Koeripan. Ook de heuvels tusschen de Sako en de Selaboeng bestaan grootendeels uit deze kalksteenen, welke in alle eenigszins diepe insnijdingen, die de beekjes hebben gemaakt, te voorschijn komen. Behalve in Makakau, komt dezelfde etage van het eoceen nog voor boven Batoe-Radja, hoofdplaats van de onderafdeeling Ogan-Oeloe, waar zij, ten Zuiden van de Ogan-rivier, eene van Oost naar West loopende reeks vormen. - Nog is het tertiair in Zuid-Sumatra vertegenwoordigd door het mioceen en het plioceen. In sommige gevallen zijn de gesteenten van deze twee formaties zandsteenen, waarvan onder anderen een uitgestrekt terrein gevonden wordt in Rawas, ten Westen van de leien, die zich, gelijk wij zooeven gezien hebben, langs de rivier tot Napal-Litjin uitstrekken. Zandsteenen, doch verder mergels en kleisteenen, worden ook aangetroffen in het Zuidelijke gedeelte van het gebergte, dat de Redjang-landen Oostelijk begrenst, liggende tegen de oudere augietandesieten, die de kern van dit gebergte uitmaken Mioceene zanden kleisteenen ontmoet men nog langs de Lematang boven Lahat, hoofdplaats van de onderafdeeling Lematang-Oeloe. Beneden Lahat ziet men mergels en zachte fijne mergelzandsteenen, door Dr. Verbeek tot het plioceen gebracht, welke gesteenten ook langs de benedenEnim, onder de bedekking van de bruine vulkanische klei van het zeediluvium, voor den dag komen, en evenzeer aan de Ogan-rivier boven Batoe-Radja, alwaar zij met geringe helling tegen den eoceenen kalksteen liggen.

Gaan wij over naar Midden-Sumatra 138. Over het algemeen komen hier dezelfde vormingen voor als op Zuid-Sumatra, met uitzondering van de jong-tertiaire (mioceene en plioceene) afzettingen.

$138 \mathrm{Zie}$ voor het volgende: Verbeek, Topographische en geologisehe beschrijving van een gedeelte van Sumatra's Westkust, benevens de dasrbij behoorende geologische kaart in 8 bladen; Veth, Aardrijkskundige beschrijving van Midden-Sumatra, met de geologische kaart, voorkomende in den bij dit werk behoorenden atlas; Fennema, Topographische en geologische beschrijving van het Noordelijk gedeelte van het Gouvernement Sumatra's Westkust, Jaarboek van het Mijnwezen in Nederlandsch Oost-Indië, jaarg. 1887, Wetenschappelijk gedeelte, blz. 129 vv., met de daarbij behoorende geologische kaart. 
Daarentegen zijn de gesteenten van de carbonische periode, die op Zuid-Sumatra geheel ontbreken, in Midden-Sumatra zeer ontwikkeld. Deze worden vertegenwoordigd door een grauwen kalksteen, waaruit dikwijls geheele bergreeksen, onder anderen het uitgestrekte NgalauSariboe-gebergte, zijn opgebouwd, vol loodrechte wanden en spitse suikerbroodvormige toppen. Hetgeen in Midden-Sumatra verder voorkomt, doch op Zuid-Sumatra gemist wordt, zijn de gesteenten van de diabaasgroep, welke weinig jonger dan de kolenkalk zijn. $\mathrm{Wij}_{\mathrm{ij}}$ zullen nu van elk der streken in Midden-Sumatra, waar struma endemisch voorkomt, de samenstelling van den bodem nagaan.

Het veelvuldigst komt de kwaal, gelijk wij gezien hebben, in dit gebied voor in het Zuiden, in Soepajang, Alahan-Pandjang en Soengei-Pagoe. Het terrein bestaat hier voornamelijk uit oude leien, hoofdzakelijk lichtgrijze tot donkergrauwe kleileien, met kwartsgangen, slechts op enkele punten bedekt door kalksteen van de carbonische formatie. Talrijk zijn daarentegen de plaatsen waar graniet aan den dag komt: de grootere partijen zullen wel doorbraken in het leiterrein zijn; onder de kleinere zijn er echter verscheidene, die alleen in diep uitgespoelde ravijnen zichtbaar zijn, en die blijkbaar eerst blootgelegd werden door erosie van de bovenliggende leien. Ook diabaas is niet zelden in groote massa's op meerdere punten door de leien heengebroken. Verder worden jonge augiet-andesieten en basalt, afkomstig van de nog werkzame vulkanen Talang en Goenoeng-Korintji, en een weinig oude augiet-andesieten aangetroffen. Van belang is het nu na te gaan, in hoeverre kolenkalk, die, gelijk reeds werd opgemerkt, hier op enkele plaatsen voorkomt, gevonden wordt in de nabijheid van de dorpen, welke wij hiervoren min of meer als zetels van de endemie hebben leeren kennen. Hiertoe behooren Grabak en Datar, gelegen in het dal van de Sikia. Het terrein in dit dal bestaat geheel uit oude leien en graniet. Leien vormen evenzeer den bodem in den omtrek van de twee genoemde dorpen, hoewel bij Grabak diabaas zich ook voordoet. Een ander dorp, hiervoren genoemd, is Tandjoeng-Balit, gelegen aan de Poelau, een rechtertak van de Pelangki. Ook hier vindt men slechts leien. Dit is eveneens het geval in de omstreken van Soepajang. Anders echter te Lolo. De oude leigesteenten en granieten zijn in de nabijheid van deze plaats bedekt door oude augiet-andesieten en over eene vrij groote nitgestrektheid door kolenkalk. Kolenkalk doet zich verder in kleine partijen voor op enkele plekken langs de BatangHari, de Goemanti en de Sangir. Voor verreweg het grootste ge- 
deelte vloeien echter ook deze rivieren door lei- en granietterreinen, langs de Sangir over eene smalle strook bedekt door vulkanisch materiaal.

De tweede landstreek in Midden-Sumatra, door ons genoemd, waar struma voorkomt, is Tanah-Datar. De vlakte, waardoor dit landschap voor een groot deel gevormd wordt en die zich rechts van de Sello tot aan den vlakken voet van den Merapi uitstrekt, bestaat uit vulkanische gesteenten. De bergreeks, links van die rivier gelegen, bevat oude leien, hoofdzakelijk weder kleileien, met kwartsgangen, en granieten, bepaaldelijk syenietgraniet, op verschillende plaatsen bedekt door kleine partijen kolenkalk. Meer naar 't Zuiden treden, hoewel ook hier eenige kolenkalk voorkomt, de tertiaire formaties op den voorgrond, zoowel ter weerszijden van de Sello als langs de Ombilin. Dit tertiair behoort tot het eoceen, eerste en tweede etage. De eerste etage wordt vertegenwoordigd door mergelschiefers, die met zuren opbruisen, en zandsteenen van syenietgranietgruis, conglomeraten en brecciën, waarin zich onder anderen brokken kolenkalk bevinden, soms in zulk eene groote hoeveelheid, dat er kalkbrecciën ontstaan. De tweede etage van het eoceen, waardoor vooral het terrein van de Ombilin gevormd wordt, bevat zandsteenen met koollagen en kleisteenlagen. De zandsteenen, die niet met zuren opbruisen en dus geen kalk bevatten, bestaan uit kwartskorrels, donr een kleiachtig bindmiddel van lichtgele kleur verbonden. Zij bedekken de koollagen, waaronder de kleisteenlagen liggen. Deze laatsten moeten dus de bodem zijn geweest, waarop de planten groeiden, waaruit die koollagen zijn ontstaan.

Geheel uit vulkanische gesteenten bestaat het derde landschap in de Padangsche Bovenlanden, waarvan wij het bestaan van struma medegedeeld hebben gevonden, namelijk Batipoe en de X Kota. In het Westelijke gedeelte, onder anderen in de nabijheid van de hoofdplaats Padang-Pandjang, doen zich echter vrij belangrijke hoeveelheden kolenkalk voor. - Uit vulkanische gesteenten, doch onder den vorm van sedimenten, bepaaldelijk puimsteentuffen, afgezet vermoedelijk in binnenmeren in den diluvialen tijd, bestaat de ten Noorden van Batipoe en de X Kota gelegen hoogvlakte, waarvan het Noordwestelijke gedeelte tot de onderafdeeling VIII Kota en VII Loerah behoort. De hoofdplaats Palembajan van deze onderafdeeling is gelegen aan den rand van dit meerdiluvium, waar eene leireeks gevonden wordt, bestaande uit vaste kleileien, grootendeels door kolenkalk bedekt, ten Westen van welke reeks een vulkanisch terrein zich uitstrekt. - Vulkanisch materiaal, vulkanische gesteenten 
en roode vulkanische klei, tot het zeediluvium behoorende, vormt ook den bodem van Bondjol en evenzoo dien van de Ophir-districten, hoewel in het Oostelijke gedeelte een uit oude leien, hoofdzakelijk kleileien, samengesteld terrein zich voordoet. - Anders is de geognostische gesteldheid van Mahi en Kapoer-nan-sembilan. De formatie in dit gedeelte van Sumatra is bijna uitsluitend tertiair. Men vindt hier namelijk gesteenten van de eerste en de derde etage van het eoceen. De eerste etage bestaat uit zandsteenen en conglomeraten, waarvan het materiaal grootendeels af hangt van de in de nabijheid gelegen oudere gesteenten, doch die meestal kwartszandsteenen en kwartsconglomeraten zijn, terwijl de derde etage, die voornamelijk in Kapoernan-sembilan gevonden wordt, zachte klei- en mergelzandsteenen bevat, welke met zuren opbruisen, hoewel kalkvrije klei- en zandsteenen ook, doch in geringe hoeveelheid, voorkomen. Overigens ziet men hier en daar, bij voorbeeld aan de grenzen van het district Mahi, reeksen van oude leien en granieten ontbloot, terwijl men in dit district ook verrast wordt door eene partij puimsteentuf, die hier in den diluvialen tijd door de Mahi moet zijn gebracht en in een klein meertje schijnt te zijn afgezet.

Omtrent de geologie van de overige strumastreken van Sumatra kunnen wij kort zijn. In Mandaïling, het dal van de Batang-Gadis, bestaat de bodem uit meerdiluvium, bepaaldelijk puimsteentuffen, tusschen bergreeksen van oude leien en granieten, op meerdere plaatsen door kolenkalk bedekt, welke onder anderen ook voorkomt in de omstreken van Pakanten en Moeara-Sipongi, waar, gelijk wij gezien hebben, struma meer in het bijzonder endemisch is 139 . Minder bekend is de geologische gesteldheid van het bovenstroomgebied van de Pane en de Bila. Volgens den Heer Neumann, zouden echter in de streken met endemische struma vele kalkbergen zijn 140. Van de binnenlanden van Deli en Serdang, de Petalangan en het stroomgebied van de Djoedjoean ontbreken alle gegevens.

Ten einde tot een duidelijk overzicht te geraken, zullen wij het hier omtrent Sumatra medegedeelde in een tabellarischen vorm samenvatten ${ }^{14} 1$.

139 Zie de, in de voorgaande noot geciteerde, verhandeling van Fennema en de daarbij behoorende geologische kaart.

140 Neumann, Het Pane- en Bila-stroomgebied, Tijdschrift van het Nederlandsch Aardrijkskundig Genootschap, 2e serie, dl. III, blz. 221-222.

141 De ouderdomsbepalingen in dit tabellarisch overzicht zijn die van Dr. Verbeek. Hieromtrent zij echter nog het volgende opgemerkt: De woude leien" 


\begin{tabular}{|c|c|c|}
\hline $\begin{array}{l}\text { LANDSCHAPPEN } \\
\text { MET } \\
\text { ENDEMTSCHE } \\
\text { STRUMA. }\end{array}$ & GESTEENTEN WAARUIT DE BODEM BESTAAT. & $\begin{array}{l}\text { OUDERDOM } \\
\text { DER } \\
\text { GESTEENTEN. }\end{array}$ \\
\hline Redjang-landen & $\begin{array}{l}\text { Vulkanische gesteenten (augiet-andesie- } \\
\text { ten en basalt) }{ }^{1} \text { en puimsteentuf }{ }^{2} \text {, tusschen } \\
\text { bergreeksen van oudere augiet-andesieten }{ }^{3} \text {, } \\
\text { ten deele bedekt door zachte zandsteenen, } \\
\text { mergels en kleisteenen } 4 .\end{array}$ & $\begin{array}{l}{ }^{1} \text { Kwartair en recent. } \\
\text { Kwartair (meerdilu- } \\
\text { vium). } \\
{ }^{3} \mathrm{~K} \text { wartair (oud-mioceen). } \\
\text { Tertiair (jong-mioceen). }\end{array}$ \\
\hline Pasemah. & $\begin{array}{l}\text { Vulkanische gesteenten (augiet-andesie- } \\
\text { ten en basalt) ' }\end{array}$ & ' Kwartair en recent. \\
\hline Makakau. & $\begin{array}{l}\text { Het geheele plateau, waartoe Makakau } \\
\text { behoort, bestaat uit puimsteentuf } 1 \text {, tus- } \\
\text { schen reeksen van oude leien (kleileien) }{ }^{2} \text { en } \\
\text { graniet-gesteenten (granitiet en dioriet) }{ }^{3} \text {. } \\
\text { Onder de puimsteentuffen bevinden zich la- } \\
\text { gen van mergels, mergelkalk en kalksteen } \\
\text { die op verschillende plaatsen langs de } \\
\text { beddingen der rivieren ontbloot zijn. }\end{array}$ & $\begin{array}{l}\text { Kwartair (meerdilu- } \\
\text { vium). } \\
2 \text { Devonisch of silurisch. } \\
\text { 3 V6ór-carbonisch. } \\
\text { ' Tertiair (eoceen, vierde } \\
\text { etage. }\end{array}$ \\
\hline Belalau. & $\begin{array}{l}\text { Puimsteentuf ' } \\
\text { nische gesteenten (augiet-andesieten en } \\
\text { basalt) }{ }^{2} \text {. }\end{array}$ & $\begin{array}{l}1 \text { Kwartair (meerdilu- } \\
\text { vium). } \\
2 \text { Kwartair en recent. }\end{array}$ \\
\hline
\end{tabular}

zijn allen opgegeven als devonisch of silurisch, dus palaeozoisch. Intusschen zou een gedeelte daarvan wel azoisoh kunnen zijn, daar leien van dezen ouderdom zich ook, zij het spaarzaam, op Sumatra voordoen (Verbeek, O. c., blz. 176-177). Overigens verwijzen wij naar noot 155 hierbeneden, waaruit blijkt dat het niet onwaarschijnlijk is, dat er onder deze gesteenten zich ook mesozoische vormingen bevinden. - De granieten zijn vóor-carbonisch genoemd. Gangen van granieten zijn toch niet gevonden in de kolenkalk, waarin een negatief bewijs gelegen is voor den hoogeren dan carbonischen ouderdom dier gesteenten (Verbeek, O. c., blz. 244). De diabazen zijn als post-carbonisch opgegeven, daar zij waarschijnlijk wel spoedig na de afzetting van de kolenkalk tot eruptie zijn gekomen (Verbeek, O. c., blz. 270). Ook van het tertiair zijn de ouderdomsbepalingen van de versohillende lagen die van Dr. Verbeek. Opgemerkt moet echter worden, dat door Prof. Martin, op palseontologische gronden, de eoceene ouderdom van de gesteenten, door Verbeek tot de $3 e$ en de 4 e etage gebracht, de mergelzandsteenen en de kalksteenen, wordt betwijfeld. Volgens hem zouden deze gesteenten oud-mioceen zijn (Martin, Tertiärsohichten auf Java, Allgemeiner Theil, blz. 36-37; Jungtertiäre Ablagerungen im Padangschen Hochlande auf Sumatra, en Neue Fundpunkte von Tertiär-Gesteinen im Indischen Archipel, Jaarboek van het Mijnwezen in Nederlandsch Oost-Indië, jaarg. 1882, Wetenschappelijk gedeelte, blz. 169-178 en 312-331). - Wat eindelijk het kwartair betreft, is, met betrekking tot het meerdiluvium, het opgemerkte, in het slot van noot 137 hierboven, te vergelijken. 


\begin{tabular}{c|c}
\hline $\begin{array}{c}\text { LANDSCHAPPEN } \\
\text { MET }\end{array}$ & GESTEENTEN WAARUIT DE BODEM BESTAAT. \\
$\begin{array}{c}\text { ENDEMISCHE } \\
\text { STRUMA. }\end{array}$ & OUDERDOM \\
\hline
\end{tabular}

Vallei van de Vulkanische gesteenten (augiet-andesie- 1 Kwartair en recent. Lematang en ten en basalt) 1 en bruine vulkanische ${ }^{2}$ Kwartair (zeediluvium). de Enim. $\quad k l e i{ }^{2}$, waaronder zand- en kleisteinen ${ }^{3},{ }^{3}$ Tertiair (mioceen). benevens mergels en zachte, fijne mergel- + Tertiair (plioceen). zandsteenen ' zich bevinden, die hier en daar langs de rivieren ontbloot zijn.

Vallei van de Bruine vulkanische klei ${ }^{1}$. Langs de ${ }^{1}$ Kwartair (zeediluvium). Ogan en de Ogan zijn, over eene vrij belangrijke uit- 2 Tertiair (eoceen, vierde Komering. gestrektheid, kalksteen ${ }^{2}$ benevens mergels en zachte, fijne mergelzandsteenen ont- 3 Tertiair (plioceen). bloot ${ }^{3}$.

Rawas. $\quad$ Oude leien (kleileien) ${ }^{1}$, zandsteenen ${ }^{2}$ en bruine vulkanische klei ${ }^{3}$.

1 Devonisch of silurisch. 2 Tertiair (jong-mioceen). ${ }^{3} \mathrm{~K}$ wartair (zeediluvium).

Stroomgebied van de Toelang-Bawang.

Stroomgebied van de Sipoetih.

Serampei.

Soepajang, Alahan-Pandjang en SoengeiPagoe.

\section{Stroomgebied van de Djoe- djoean.}

Tanah-Datar.

Bruine vulkanische klei 1 en zachte, ' Kwartair(zeediluvium). witte of lichtgrijze tuffen van eene kleiachtige of kaolienachtige zelfstandigheid ${ }^{1}$.

Zandsteenen en conglomeraten, rustende op granitiet en uit de vergruizingsproducten van dit gesteente opgebouwd ${ }^{1}$, en bruine ${ }^{2}$ Kwartair (zeodiluvium). vulkanische klei ${ }^{2}$.

Onbekend.

Oude leien (kleileien) ${ }^{1}$, op talrijke ${ }^{1}$ Devonisch of silurisch. plaatsen doorbroken door granieten ${ }^{2}$ en 2 V66r-carbonisch. diabazen ${ }^{3}$, en pleksgewijze bedekt door ${ }^{3}$ Post-carbonisch. kolenkalk 4 . Verder oude augiet-andesieten ${ }^{5}$ ' Carbonisch. en vulkanische gesteenten (augiet-andesie- ${ }_{5}^{5}$ Tertiair (oud-mioceen). ten en basalt) ${ }^{6}$.

6 Kwartair en recent.

Onbekend.

Vulkanische gesteenten ', begrensd door 1 Kwartair en recent. oude leien ${ }^{2}$ en granieten (syenietgraniet) ${ }^{3},{ }_{2}$ Devonisch of silurisch. hier en daar door kleine partijen kolenkalk 4 , 3 Vór-carbonisch. bedekt. Verder mergelschiefers en zand- $\mid$ ' Carbonisch. 


\section{LANDSCHAPPEN MET ENDEMISCHE STRUMA.}

OUDERDOM

DER

GESTEENTEN.

steenen van syenietgranietgruis met con- 5 Tertiair (eoceen, eerste glomeraten en brecciën, waarin zich brokken kolenkalk bevinden ${ }^{5}$. Kalkvrije kwartszandsteen met kool- en kleisteenlagen ${ }^{6}$. etage).

6 Tertiair(eoceen, tweede etage).

Batipoe en de X Kota.

VIII Kota en VII Loerah.

Bondjol.

Ophir-districten.

Mahi. Kapoer-nan-
sembilan.

Mandaïling.

Boven-Pane en Boven-Bila.

Bovenlanden van Deli en Serdang.

Petalangan.
Vulkanische gesteenten. Hier en daar ligt kolenkalk ${ }^{2}$ ontbloot.

Vulkanische gesteenten ${ }^{1}$ en puimsteentuffen ${ }^{2}$, van elkander gescheiden door eene reeks oude leien (kleileien) ${ }^{3}$, grootendeels bedekt door kolenkalk ${ }^{7}$.

Vulkanische gesteenten ', en roode vulkanische klei 2 .

Vulkanische gesteenten ${ }^{1}$ en vulkanische klei ${ }^{2}$, Oostelijk begrensd door een terrein van oude leien (kleileien) ${ }^{3}$.

Kwartszandsteenen en kwartsconglomeraten ${ }^{1}$ met eene partij puimsteentuf ${ }^{2}$. Zuidelijk en Oostelijk vindt men reeksen van leien ${ }^{3}$ en granieten ${ }^{4}$.

Zachte kleisteenen en mergelzandsteenen ', die, met kleine hoeveelheden kalkvrije klei- en zandsteenen ', afgezet zijn op en rondom kwartszandsteenen en kwartsconglomeraten ${ }^{2}$.

Puimsteentuffen 1, besloten tusschen bergreeksen van oude leien ${ }^{2}$ en granieten ", op verschillende plaatsen bedekt door kleine partijen kolenkalk 4 .

Dit terrein is geologisch nog niet onderzocht, doch zouden hier onder anderen ook kalkgesteenten 1 voorkomen.

Onbekend.

Onkekend,
Kwartair en recent.

2 Carbonisch.

1 Kwartair en recent.

2 Kwartair (meerdiluvium).

3 Devonisch of silurisch.

4 Carbonisch.

Kwartair en recent.

${ }^{2}$ Kwartair (zeediluvium)

1 Kwartair en recent.

Kwartair (zeediluvium)

3 Devonisch of silurisch.

Tertiair (eoceen, eerste etage).

2 Kwartair (meerdiluvium).

3 Devonisch of silurisch.

- V66r-carbonisch.

1 Tertiair (eoceen, derde etage).

2 Tertiair (eoceen, eerste etage).

Kwartair (meerdiluvium).

2 Devonisch of silurisch.

Vóor-carbonisch.

- Carbonisch.

1 Onbekend. 
Volledigheidshalve willen wij nog de geologische vorming nagaan van de verschillende struma-districten op Borneo en de overige eilanden.

Het is van genoegzame bekendheid, dat de oudste gesteenten van Borneo ${ }^{142}$ granieten (graniet en syeniet) en "oude leien" zijn, waaronder hier ook de azoische, de typische, kristallijne, leivormingen voorkomen, hoofdzakelijk door glimmer- en hoornblende-leien vertegenwoordigd ${ }^{143}$, die met eenige relatief jongere, doch in allen gevalle vóór-tertiaire, eruptieve gesteenten, gabbro, dioriet en serpentijn, het grondgebergte van het eiland uitmaken. Dit grondgebergte wordt omzoomd door tertiaire afzettingen, die voor het grootste gedeelte behooren tot het eoceen, dat in drie etages, eene zandsteen-etage, met kolenvlotten, eene mergel- en eene kalksteen-etage, voorkomt ${ }^{144}$. Tot het tertiair behooren nog eenige eruptieve gesteenten, die waarschijnlijk na de afzetting van het jongste lid van het eoceen, den kalksteen, tot doorbraak zijn gekomen, namelijk andesieten (augieten hoornblende-andesieten), welke steeds vergezeld zijn van tuffen en tufconglomerateu. Horizontaal of met geringe helling tegen en op deze eruptieve gesteenten, vindt men jongere tertiaire afzettingen, bestaande uit klei- en zandsteenen, waarvan de ouderdom tot dusverre niet met zekerheid bepaald is kunnen worden, doch die evengoed tot eene jongere afdeeling van het eoceen als tot het mioceen kunnen behooren $144 \mathrm{a}$. De tertiaire afzettingen vormen het heuvelland van Borneo, in tegenstelling van de weinig golvende of vlakke terreinen, die uit kwartaire sedimenten, diluvium en alluvium, bestaan.

142 Een overzicht van de geologie van Borneo, vindt men bij: Martin, Begeleidende woorden bij eene geologische kaart van Borneo, Tijdsohrift van het Nederlandsch Aardrijkskundig Genootschap, dl. VII, blz. 16 vv., en Die wichtigsten Daten unserer geologischen Kenntniss vom Niederländisch Ost-Indischen Arohipel, Bijdragen tot de T. L. en Vk. van Nederl. Indië, uitgegeven ter gelegenheid van het Orientalisten Congres te Leiden, blz. 22 vlg.

143 Voor Borneo zijn dus, evenals voor Sumatra (zie noot 14l), onder de benaming "oude leien" te verstaan, zoowel de azoisohe, de typische, kristallijne, leivormingen, als de leivormingen welke als palaeozoisch, devonisch of siluriseh, plegen beschouwd te worden, doch die, gelijk straks zal blijken, althans in sommige streken, mesozoisch zijn.

144 Door Verbeek worden deze etages angeduid met de letters $\alpha, \beta$ en $\gamma$ Zij zijn aequivalent aan de etages II, III en IV van het eoceen van Sumatra.

$144 a$ Ten aanzien van de ouderdomsbepalingen der verschillende tertiaire lagen, loopen de meeningen van Prof. Martin en Dr. Verbeek uiteen. Evenals van de etages III en IV van Sumatra, wordt toch door Martin van de daarmede aequivalente etages $\beta$ en $\gamma$ van Borneo de eoceene ouderdom betwijfeld. Zij moeten, volgens hem, ou d-mioceen ziju (Zie zijne in noot 141 geciteerde verhandelingen). 
Het diluvium, dat als een breede band overal het tertiair begrenst, doch ook, ofschoon in mindere mate, tusschen eoceene heuvels optreedt, is eene zanderige, door ijzeroxydehydraat geel gekleurde klei, die langzamerhand in eene zachtere en fijnere grauwe klei, het alluvium, overgaat.

In het strumagebied van de Beneden-Barito, dat is dus het landschap tusschen de Barito en het Meratoes-gebergte, bespoeld door de Martapoera-rivier met hare beide armen, de Riam-Kiwa en de RiamKanan, Tanah-Laoet en Doesoen-Timor, komt struma, gelijk wij gezien hebben, vooral voor in de heuvelenformatie, op tertiaire vormingen dus 145 . In het eerstgenoemde landschap wordt het tertiair door de drie etages van het eoceen vertegenwoordigd ${ }^{146}$. Men heeft hier dus zandsteenen met kolenvlotten, verder mergels, in verschillende varieteiten en met verschillend kalkgehalte, en kalksteen. Vooral deze laatste heeft hier eene groote ontwikkeling. Eene bijna onafgebroken reeks daarvan laat zich toch van het dorp Matraman, langs de Riam Kiwa en verder langs een rechtertak van deze, de Mangkaoek, vervolgen tot de kalkgrot Goenoeng-Batoe-Hapoe 146a. Ook de jong-tertiaire (mioceene?) afzettingen, de klei- en zandsteenen, ontbreken hier niet, evenmin als de tertiaire eruptieve gesteenten, augiet- en hoornblende-andesieten, die het materiaal voor dat jonge tertiair geleverd hebben. De kleisteenen zijn soms mergelachtig door een gering kalkgelialte, terwijl de meeste zandsteenen

145 Volledigheidshalve zij hier opgemerkt, dat Prof. Martin kortelings tot de ontdekking is gekomen van het bestaan, in deze heuvelenformatie in het gebied van Martapoera, van mesozoische, bepaaldelijk oretaceische, vormingen (Martin, Ueber das Vorkommen einer Rudisten führenden Kreideformation im Südöstlichen Borneo, en Die Fauna der Kreideformation von Martapoera, Jaarboek van het Mijnwezen in Nederlandsch Oost-Indië, Wetensohappelijk gedeelte, jaarg. 1888, blz. 72 vv., en jaarg. 1889 , blz. 3 vv.).

$1+6$ Zie voor het volgende: Verbeek, Geologische beschrijving der districten Riam-Kiwa en Kanan, in de Zuider- en Ooster-Afdeeling van Borneo, Jaarboek van het mijnwezen in Nederlandsch Oost-Indië, jaarg. 1875, dl. I, blz. 10 vv.

$146 a$ De rivieren loopen zeer dikwijls tussehen de gesteenten der etages $\alpha$ en $\gamma$ eoceen, terwijl de ruimte waar zich de etage $\beta$ moest bevinden, opgevuld is met rivier-alluvium. Dit laat zich gemakkelijk verklaren doordat de zandsteenen der etage $\alpha$ en de kalksteenen der etage $\gamma$ in het algemeen vrij hard zijn, terwijl de mergels van de etage $\beta$ eene veel geringere vastheid bezitten; door het water werd daarom voornamelijk het aan den dag komende der zachte lagen van de etage $\beta$ weggespoeld, en in de plaats daarvan rivier-alluvium afgezet, terwijl de harde lagen der etages $\alpha$ en $\gamma$ behouden bleven (Verbeek, 0. c., blz. 109-110). 
ook een weinig carbonaten bevatten en dus met zuren opbruisen. In Tanah-Laoet vertoont het tertiaire heuvelland hetzelfde karakter als in Martapoera, hoewel de zandsteenen er eene grootere uitbreiding schijnen te hebben dan de mergels en kalksteenen ${ }^{147}$. - Van DoesoenTimor zijn de berichten omtrent de geologische gesteldheid minder volledig. Zeker is het, dat het tertiair ook hier zeer ontwikkeld is, en "durch manche Eigenarten sich als identisch mit dem Tertiär von Pengaron (Martapoera) erwies, oder als solches angenommen werden muss" 148. Dit geldt voornamelijk van de kalksteenen, die zich van Martapoera tot diep in de binnenlanden uitstrekken ${ }^{149}$, en dus ook in Doesoen-Timor worden aangetroflen. De meeste van de hier optredende heuvels, zegt Schwaner, zijn voorzien van zachte hellingen, en bestaan, voor zooverre het mogelijk was, hun geologisch karakter na te gaan, uit poreuzen kalksteen ${ }^{150}$. Oostelijk van deze vorming treft men voornamelijk ijzerhoudende zandsteenen 151. - Behalve in de heuvellanden, op tertiairen bodem, kount struma, in het Zuidoosten van Borneo, in de, uit diluviale afzettingen, gele zanderige klei, bestaande, vlakke streken, bepaaldelijk van Margasari en Benoewa-Ampat, en verder in het gebied der Orang-Bukit. Voor een deel is dit gebied gelegen in het, uit oude, hier bepaaldelijk kristallijne, leien (hoornblende- en glimmer-leien), granieten en jongere, doch in allen gevalle vó́r-tertiaire, eruptieve gesteenten (gabbro, dioriet en serpentijn) samengestelde, Merstoes-gebergte en de, onmiddellijk Westelijk daaraan grenzende, tertiaire heuvellandeu; voor een ander deel echter ook in de heuvelenformatie ten Oosten van dat gebergte, immers in het brongebied van de Koesan- of $\mathrm{Pa}$ gatan-rivier. Ook hier treden de kalksteenvormingen op den voorgrond, en schijnen "in fast ununterbrochener Reihe sioh lings dem Gebirgs-

147 Posewitz, Borneo, blz. 138.

148 Posewitz, Borneo, blz. 138-189.

149 Een goed overzicht van de kalkformntie in dit gedeelte van Borneo heoft men van Negara, bij hoogen waterstaud. HIeh aah vor mir", sehrijft Porewitz, "so weit das Auge reichte die sumpfigen Niederungen su einem Meere ausgedehut, welches sioh scheinbar auszudehnen sehion bis an den Fuss der im Oater बieh hinziehenden Bergkette des Pramasan-, Amandit- und Alaigebirgen, Uud lăng diesem Gebirge zog sioh hin eine Reihe steiler Kalkfelsen, die unmittelbür vom Wasser bespült schienen. Man konnte sieh hier surüekdenken in die Zeit dow Beginnes der Diluvialperiode, und erhielt ein genauea Bild des damaligen Bornean (Posewitz, Borneo, blz. 144).

150 Sehwaner, Borneo, dl. I, blz. 95. Zie ook: Posewitz, Borneo, bls. 14k,

151 Sehwaner, Borneo, dl. I, blz. 91 en 96; Posewitz, Borneo, bls. 140 , 
rande bis gegen die nördliche Grenze von Passir hiuzuziehen. Sie bilden steile Felsen mit Höhlen versehen, in welchen der Fluss zuweilen verschwindet, um späterhin wieder zum Vorschein zu kommen" 152 .

Gaan wij nu over naar de Wester-Afdeeling van Borneo en naar Sarawak, waar wij meer bepaaldelijk de geognostische gesteldheid na te gaan hebben van het breede dal van de Melawi en van het brongebied van de Sikajam met dat van de Sarawak- en van de Samarahanrivier. Niet minder dan in het Zuidoosten van het eiland, is het tertiair hier ontwikkeld. Dat van het bekken van de Melawi is echter slechts oppervlakkig onderzocht, doch schijnt het weinig kalksteen en mergelformaties te bevatten, en hoofdzakelijk uit zandsteen te bestaan ${ }^{153}$. Overigens strekt zich langs beide oevers eene breede strook diluviale en alluviale afzettingen uit. - Beter bekend is het brongebied van de Sikajam ${ }^{154}$. Het terrein bestaat hier in de eerste plaats uit oude leien, kleileien, in het Noordelijke, en kiezelleien, in het Zuidelijke gedeelte, geheel identiek aan die, welke in de Westelijker gelegen streken aangetroffen worden, en, blijkens eenige daarin gevonden, door Prof. Martin onderzochte, versteeningen, niet, zooals men aanvankelijk meende, devonisch, dus palaeozoisch, doch mesozoisch, misschien cretaceisch, zijn 155. Behalve deze leien,

152 Posewitz, Borneo, blz. 165; Von de Wall, Overzicht van het rijk van Koetei en de Oostkust van Borneo, Indisch Archief, jaarg. 1850, dl. III, blz. 466-467, 468 en 471, waar bepaaldelijk over de kalksteenformaties in het door de Orang-Bukit bewoonde gebied van Koesan gesproken wordt.

153 Posewitz, Borneo, blz. 158.

154 Van Schelle, De geologisch-mijnbouwkundige opneming van een gedeelte van Borneo's Westkust, Jaarboek van het Mijnwezen in Nederlandsch Oost-Indië, jaarg. 1884, Technisch en administratief gedeelte, blz. $123 \mathrm{vv}$.

155 De voorloopige ouderdomsbepaling van deze leien als devonisch, geschiedde na een oppervlakkig onderzoek van de over het algemeen slecht bewarde petrefacten. Te eerder.neigde men tot het devon, dewijl de leien petrographisch gelijk zijn aan de "oude leien" op Sumatra, die men op stratigraphische gronden, dewijl zij door de afzettingen van de carbonische formatie bedekt worden, steeds als devonisch of silurisch beschouwd heeft. De vraag rijst nu vanzelf op, of deze Sumatraansche leien ook niet mesozoisch (cretaceisch) zijn. "Unter allen Unständen", zegt Martin, "ist das negative Resultat eines nicht palaeozoischen Alters der sog. alten Schieferformation von Borneo für die Geologie von Niederländisch-Indien von grosser Tragweite; denn dieselbe Formation ist an manchen anderen Orten, soweit petrographische Charaktere ein Urtheil zulassen, nachgewiesen. Van Schelle selbst theilte mir mit, dass die alten Schiefer von Borneo wabrscheinlich aequivalent mit denen von West-Sumatra seien, und ich kann mich nach dem Studium der einschlägigen Literatur des Eindrucks nicht erwähren, als ob dieselbe meso- 
treft men, in het brongebied van de Sikajam, nog op enkele plaatsen, in geisoleerde partijen, zandsteenen en conglomeraten aan, waarvan de ouderdom niet met zekerheid bepaald kan worden, doch die waarschijnlijk als oud-eoceen zijn te beschouwen 156. Van de eruptieve gesteenten vindt men hier alleen gabbro, die de kern uitmaakt van het gebergte, aan den rechteroever van de Sikajam gelegen. Kalksteen komt in het geheele gebied niet voor. Vermelding verdient het echter, dat iets Westelijker, langs den bovenloop der Siding-rivier; een rechtertak van de Sambas, kalksteenbanken zich voordoen 157. - Hoedanig de geognostische gesteldheid is van het brongebied van de Sarawak en de Samarahan, kan moeielijk met zekerheid worden gezegd. De mijningenieur Van Schelle, die van Siding uit, het grens-, dat is het waterscheidend, gebergte overtrok, bevond dit uit graniet te bestaan, terwijl hij aan beide zijden volkomen identieke kleileien aantrof ${ }^{158}$. Het is echter zeker, dat, zoo niet bepaaldelijk bij dit grensgebergte, dus in het gebied waar door Denison struma werd waargenomen, dan toch iets Noordelijker, kalksteenen in groote hoeveelheid worden gevonden, die volgens sommigen van de carbonische formatie zouden zijn ${ }^{159}$.

Wij zien dus, om het medegedeelde kortelijk samen te vatten, hoe op Borneo, in het stroomgebied van de Beneden-Barito, waar de zetels van de endemische struma gevonden worden, de bodem, behalve uit azoische vormingen, kristallijne leien, en oude eruptieve gesteenten, hoofdzakelijk uit tertiaire, in eene enkele streek ook uit kwartaire (diluviale), afzettingen bestaat, en hoe, onder het tertiair, kalksteenen veelvuldig aangetroffen worden, benevens andere

zoische (cretaceische) Formation durch verschiedene Geologen zum Theil als Tertiaer zum Theil als palaeozoisch bezeichnet worden sei. Wie das mit den Lagerungsverhältnissen in Einklang zu bringen ist, kann ich freilich aus der Ferne nicht beurtheilen, und muss ich mich begnügen, die hier hervorgehobene Möglichkeit zur näheren Untersuchung den in Indien beschäftigten Ingenieuren anheimzustellen" (Martin, Versteinerungen der sogenannten alten Schieferformation von West-Borneo, Jaarboek van het Mijnwezen in Nederlandsch Oost-Indië, jaarg. 1889, Wetenschappelijk gedeelte, blz. 75 vv.).

156 Volgens Van Schelle (zie zijne, in noot 154, aangehaalde verbandeling, blz. 139-140), misschien aequivalent aan de etage I van het eoceen van Sumatra. 157 Volgens eene mededeeling van Van Schelle, Jaarboek van het Mijnwezen in Nederlandsch Oost-Indië, jaarg. 1883, Technisch en administratief gedeelte, blz. 91 . 158 Jaarboek van het Mijnwezen in Nederlandsch Oost-Indië, jaarg. 1883, Technisch en administratief gedeelte, blz. 90 .

159 Zie: Posewitz, Borneo, blz. 126 vv., en de in dit werk voorkomende geologische kaart. 
kalk in meerdere of mindere mate bevattende sedimenten, als mergels en de jong-tertiaire (mioceene?) mergelachtige kleisteenen. Ook in Sarawak schijnen kalksteenen, volgens sommigen van de carbonische formatie, in het brongebied van de Sarawak en de Samarahan, zoo niet bij de zetels der endemie, dan toch in de nabijheid daarvan, overvloedig voor te komen. Geheel anders in het stroomgebied van de Kapoeas. Kalksteenen schijnen hier in het algemeen zeldzaam te te zijn 160 , in de streken met endemische struma, in het brongebied van de Sikajam en het dal van de Melawi, zelfs zoogoed als geheel te ontbreken. Het zijn mesozoische, vermoedelijk cretaceische leivormigen, kleileien en kiezelleien, en tertiaire (oud-eoceene?) zandsteenen en conglomeraten, benevens oude eruptieve gesteenten, gabbro, die bepaaldelijk in de eerstgenoemde landstreek optreden.

Over de overige eilanden kunnen wij kort zijn.. Onbekend is toch de geognostische gesteldheid van Bali en van Centraal-Celebes, terwijl wij geene bijzonderheden weten van de formaties van dat deel van Timor en van het gebied van de Dorei-baai op NieuwGuinea, waar door Forbes en Von Rosenberg de gevallen van struma zijn geconstateerd. Wat Java betreft 161, het is van genoegzame bekendheid, dat de bodem van dit eiland hoofdzakelijk tertiair is. Wel is het bestaan van oudere sedimentaire formaties, oude leien, en van oudere eruptieve gesteenten, aangetoond; doch een feit is het, dat deze minder aan de oppervlakte liggen dan bij voorbeeld op Sumatra 162. Overigens hebben jongere eruptieve gesteenten een groot andeel gehad in de vorming van het eiland. Behalve de tertiaire, misschien post-eoceene, andesieten (augiet- en hoornblendeandesieten) en trachieten, vindt men nog soortgelijke producten die van de hedendaagsche, uitgedoofde of nog werkzame, vulkanen af-

160 Volgens Van Schelle, Jaarboek van het Mijnwezen in Nederlandsch Oost-Indië, jaarg. 1883, Technisch en administratief gedeelte, blz. 91.

161 Een overzicht van de geologie van Java, vin 1 t men bij: Martin, Die wichtigsten Daten unserer geologischen Kenntniss vom Niederländisch Ost-Indischen Archipel, Bijdragen tot de T. L. en Vk. van Nederl. Indië, uitgegeven ter gelegenheid van het Orientalisten Congres te Leiden, blz. 20 vlg., en Verbeek, Over de geologie van Java, Tijdschr. van het Nederl. Aardrijkskundig Genootschap, dl. I, blz. 291 vv.

162 Het verschil tussohen deze beide eilanden is, gelijk Prof. Martin dit opmerkt (0. c., blz. 21), geenszins qualitatief, doch slechts kwantitatief, alleen daarin gelegen, "dass Java zur Tertiaerzeit weiter untergetaucht war als Sumatra und dadurch eine ausgedehntere Entwicklung tertiaerer Sedimente begünstigte, indem gleichzeitig die auf Java jetzt unbekannten, mit sumatranischen aequivalenten Bildungen von der Tertiaerformation überdeckt wurden", 
komstig zijn. Tot het tertiair behooren, behalve zandsteenen en mergels, ook kalksteenen van verschillenden ouderdom. Sommigen behooren tot het eoceen (aequivalent aan de vierde etage van het eoceen op Sumatra), doch de meesten zijn jonger. Op talrijke plaatsen, vooral op Oost-Java, worden toch de jong-mioceene lagen door kalkbanken bedekt, die de bovenste, jongste, afdeeling van de geheele tertiaire periode vormen, en die men daarom voorloopig plioceen heeft genoemd. Zoo is dit, om ons alleen tot de streken te bepalen waar struma het meest voorkomt, het geval in Jogjåkartå en Kediri. Gelijk wij gezien hebben, wordt de eerstgenoemde residentie grootendeels ingenomen door eene vlakte, in het midden waarvan de hoofdplaats gelegen is. De vorm van deze vlakte is die van eene ruit, met de langste diagona 1 zich uitstrekkende van den Merapi, ten Noorden, tot aan den mond van de Oepak-rivier, ten Zuiden. De bodem bestaat uit vulkanische gesteenten, tuf- en aschlagen. Ten Zuidoosten en ten Zuidwesten van deze vulkanische vlakte, dat is ten Oosten van de Oepak en ten Westen van de Prågå, strekt zich een gebied uit, resp. bedekt door den Goenoeng-Kidoel en het Kelir-gebergte. Beide gebergten bestaan uit tertiaire vormingen, regelmatige lagen zandsteen, mergel en kleisteen, bedekt door dikke horizontale lagen kalksteen, die vooral in den Goenoeg-Kidoel zeer ontwikkeld zijn, zich tot aan de zee onafgebroken voortzetten en daar eene gemiddeld 80 M. hooge kust vormen. Doch ook op de vulkanische vlakte doen zich kalksteenvormingen voor. Ten Zuiden van de hoofdplaats verheffen zich namelijk talrijke kalksteenheuvels, die gaandeweg meer de overhand krijgen, totdat op ongeveer $4 \frac{1}{2}$ KM. van de kust het vulkanisch terrein niet meer dan 5 KM. breed is. Een gordel van kalksteenheuvels omringt dus de vlakte van Jogjåkartå ten Zuiden, en vormt het verband tusschen de kalksteenformaties in de Oostelijke en de Westelijke berglanden, den Goenoeng Kidoel en het Kelir-gebergte ${ }^{163}$. - W W Kediri betreft, ook hier zien wij hoe de kalksteenvormingen, vooral in het Zuiden en in het Noorden de overhand hebben. Overigens bestaat de bodem uit vulkanisch materiaal, dat op de vlakte, waar tijd tot verwering niet ontbroken heeft, in eene helder grijze klei is overgegaan, welke

163 Van Dijk, Geologische beschrijving der residentie Djokdjakarta, Jaarboek van het Mijnwezen in Nederlandsch Oost-Indië, jaarg. 1872, dl. I, blz. 149 vv.; Veth, Java, dl. III, blz. 611 vlg. Zie ook vooral blz. 641 vlg., waar eene meer uitvoerige beschrijving voorkomt van de kalkheuvelen ten Zuiden van Jogjåkartå. 
bij droogte hard en korstig wordt, bij overvloedige besproeiing in eene taaie modder verandert $\mathbf{1 6 4}$.

Toetsen wij nu het hiervoren medegedeelde aan de conclusie, waartoe Hirsch, op grond van zijne onderzoekingen omtrent het verband tusschen geologische vorming en struma-endemie, gekomen is. Uit die onderzoekingen blijkt, volgens hem, vooreerst, dat "keine geologische Formation das Vorkommen von Kropf ausschliesst", en verder, dat deze kwaal "wenn auch nicht ausschliesslich, doch viel häufiger auf den älteren Formationen (einschliesslich der Trias-Gruppe), als auf den jüngeren angetroffen wird, und dass sie auch, wie es scheint, nur auf solchem Diluvium vorkommt, welches von Detritus ailterer Formationen gebildet ist" 165 . Het eerste vinden wij in den Indischen Archipel bevestigd : ook hier is de struma niet an eene bepaalde geologische formatie gebonden. Anders echter wat de tweede conclusie betreft. Wel zien wij hoe op Java, waar minder oude gesteenten en meer tertiaire sedimenten voorkomen dan op Sumatra, ook struma minder algemeen is, doch is tusschen deze twee verschijnselen geen causaal verband aan te nemen. Beschouwen wij toch Sumatra op zichzclf, dan bemerken wij juist het omgekeerde: oude vormingen doen zich in Midden-Sumatra overvloediger voor dan op Zuid-Sumatra, daarentegen is struma hier meer eene endemische kwaal dan ginds. Feitelijk zijn dan ook de oudere sedimenten in de strumadistricten uiterst zeldzaam. Behalve de weinige kristallijne leien van de azoische periode, zijn het, van den palaeozoischen, dat is carbonischen, devonischen of silurischen, tijd, alleen kolenkalk en de zoogenaamde "oude leien", voor zoover deze althans niet behooren tot de mesozoische, bepaaldelijk cretaceische, formatie, die daar aangetroffen worden. Daarentegen treden er de tertiaire vormingen allerwege op den voorgrond, en verder de kwartaire, diluviale, zee- en zoetwater-afzettingen, meestal van vulkanisch materiaal. Ook wat de eruptieve gesteenten betreft, zijn zeker de jongere, jong-tertiaire on posí-tertiaire, meer vertegenwoordigd dan de oudere 166. Voor het

$16+$ Veth, Java, dl. III, blz. 732 vlg.

165 Hirsch., Handbuoh der historisch-geographischen Pathologie, dl. II, blz. 117.

166 Onder de medici, die in den laatsten tijd uitvoerig het verband hebben trachten na te gaan tusschen de endemische struma en de geologische vorming van den bodem, behoort ook Bircher, die zijne onderzoekingen voornamelijk in Zwitserland instelde. De uitkomsten, waartoe hij gerakte, zijn, »dass der Kropf in enger Beziehung zu der geologischen Bodenformation steht und in der Sohweiz auf den Sedimenten des triasischen, des eocenen und des miocenen Meeres vor- 
overige geldt ook ten aanzien van den Indischen Archipel ten volle de opmerking van Hirsch $16 \mathbf{6 a}$, dat, in aanmerking genomen "die oft sehr enge locale Begränzung der Krankheitsheerde, die Beschränkung derselben auf einzelne Ortschaften bei vollkommenem Verschontbleiben der Umgegend derselben, oder die Immunität einzelner Punkte mitten in einem grösseren Krankheitsheerde, bei übrigens vollkommen gleicher Formation", het nauwelijks betoog behoeft, "dass der geologische Character der Formation an und für sich keineswegs entscheidend für das Vorkommen von Kropf ist" $16 \mathbf{7}$.

"Besteht nun", aldus weder Hirsch, "ein causaler Zusammenhang zwischen dem endemischen Vorherrschen von Kropf und der Bodenbeschaffenheit und zeigt sich die geologische Formation desselben hiefür nicht maassgebend, so muss das entscheidende Moment..... in der chemischen Beschaffenheit, bez. in dem mineralogischen Character desselben gelegen sein" 168 . Zoo heeft men gemeend - gelijk hiervoren reeds terloops werd opgemerkt - dat de endemische struma uit het aanwezen van kalk in den bodem moet worden verklaard. Deze theorie is herhaaldelijk verkondigd, en, met het oog daarop, hebben wij dan ook hiervoren meer in het bijzonder het voorkomen

kommt, das orystallinische Urgebirge, die Jura- und die Kreideformation, sowie die Süsswasserablagerungen aber verschont. Die Beobachtungen in andern Ländern erweitern diese Theorie, indem sie den Schluss gestatten : $1^{0}$. Der Kropf kommt nur auf marinen Ablagerungen vor und zwar auf den marinen Sedimenten des palaeozoischen Zeitalters, der triasischen Periode und der Tertiärzeit; $2^{0}$. Frei von Kropf sind die aus dem Erdinnern gluthflüssig aufgestiegenen und an der Oberfläche erstarrten Eruptivgebilde, das crystallinische Gestein der archäischen Formationsgruppe, die Sedimente des Jura- und Kreidemeeres, des quaternären Meeres, sowie sämmtliche Süsswasserablagerungen" (Bircher, Der endemische Kropf und seine Beziehungen zur Taubstummheit und zum Cretinismus, blz. 56). Hetgeen wij in den Indischen Archipel hebben gevonden, is in sommige gevallen met deze conclusie in strijd. Zoo zijn, om slechts op dit eene te wijzen, de kwartaire vormingen in den Indischen Archipel niet van de struma verschoond, en is de kwaal hier evenmin alleen tot de zee-sedimenten beperkt.

${ }^{106} a$ Hirsch, Handbuch der historisch-geographischen Pathologie, dl. II, blz. 117.

$167 \mathrm{Zij}$, die de struma beschouwen als aan bepaalde geologische vormingen gebonden, verklaren dit op verschillende wijzen. Dr. Bircher (0. c., blz. 15) neemt, in navolging van Lücke, aan, dat voor de ontwikkeling van de endemische struma noodig zijn: $" 1^{0}$. Ein Miasma, das wir noch nicht kennen, und $2^{0}$. Eine bestimmte Bodenformation, auf welcher das Miasma gedeihen kann". Welke die bodemformatie volgens Bircher is, hebben wij in noot 166 leeren kennen. - In den tekst hierbeneden zullen wij nog zien, hoe zij, die de struma beschouwen als bepaaldelijk cigen aan de oudere vormingen, dit in verband willen brengen met de meerdere aanwezigheid daarin van magnesia, die dan het eigenlijk aetiologisch moment zou zijn.

168 Hirsch, Handbuch der historisch-geographischen Pathologie, dl. II, blz. 117. 5e Volgr. V. 
van kalkgesteenten nagegaan. Uit het tabellarisch overzicht van Sumatra blijkt nu, dat, onder de vele en velerlei oudere en jongere sedimenten, die in de strumadistricten van dit eiland gevonden worden, ook - wij deden dit door cursiveering uitkomen - kalkgesteenten zich bevinden, kolenkalk, in Midden- en in NoordSumatra, en kalksteen van de jongste etage van het eoceen, in ZuidSumatra, benevens eenige kalk in meerdere of mindere mate bevattende eoceene, mioceene en plioceene afzettingen, als mergels, mergelschiefers, mergelzandsteenen, enz. Intusschen treden deze gesteenten niet op die wijze en in die mate op, dat het endemisch voorkomen van de struma daarmede in verband gebracht of daaruit verklaard zou mogen worden. Integendeel, in Midden-Sumatra, waar kalkgesteenten een voornaam bestanddeel van de bodemformatie uitmaken, is de kwaal minder algemeen $\mathbf{1 6 9}$ dan in Zuid-Sumatra, waar die gesteenten meer sporadisch en in kleiner hoeveelheden zich voordoen, niet toch den bovengrond vormen, doch de onderlaag zijn van jongere afzettingen, zooals in Makakau van de puimsteentuffen van het meerdiluvium, pleksgewijze alleen ontbloot langs de diep ingesneden rivierbeddingen. Aan den anderen kant moet het echter worden toegegeven, dat juist deze omstandigheid tot voorzichtigheid maant. "Die Schwierigkeit", merkt Hirsch te recht op, "welche sich einer Iösung dieser Frage (naar het verband tusschen het mineralogisch karakter van den bodem en de struma-endemie) entgegenstellt, liegt wesentlich in dem Umstande, dass es an einer ausreichenden und gründlichen Bestimmung der Bodenverhältnisse an den einzelnen beschränkten J Jocalitäten fehlt, welche eben Sitze des Kropfes bilden, dass zudem für das Urtheil nicht bloss die Kenntniss der oberflächlichen BodenSchicht, sondern auch die Kenntniss des von dem Character dieser oft sehr verschiedenen Untergrundes nothwendig ist" 170. Het kan wezen, dat een meer nauwkeurig onderzoek aan het licht zal brengen, dat, in meerdere streken van Zuid-Sumatra, in de diepte, door jongere afzettingen bedekt, kalksteenen aanwezig zijn, en dat ontblootingen daarvan zich ook, gelijk in Makakau, bij de zetels der endemie voordoen. Dit schijnt onder anderen het geval te zijn in het gebied van de Wai-Ompoe. Struma komt in dit gebied veelvul-

160 Van de streken, waar de kolenkalk zich niet alleen plaatselijk voordoet, doch aaneengeschakelde bergreeksen, gelijk het Ngalau-Sariboe-gebergte, vormt, vinden wij zelfs niets omtrent het voorkomen van struma vermeld.

170 Hirsch, Handbuch der historisch-geographischen Pathologie, dl. II, blz. 114. 
dig voor langs de Tahami ${ }^{\mathbf{1 7 1}}$, vooral ter plaatse waar een spruitje zich in deze rivier ontlast. De bodem bestaat hier, gelijk wij boven gezien hebben ${ }^{171 \mathrm{a}}$, uit zeediluvium, niet echter onder den gewonen vorm van eene bruine vulkanische klei, doch onder dien van zeer fijne, zachte, witte of lichtgrijze tuffen van eeve kaolienachtige zelfstandigheid. In den bovengrond wordt dus kalk in het geheel niet of slechts in onbeteekenende hoeveelheid aangetroffen ${ }^{171 b}$. Toch vinden wij vermeld dat het water van evengenoemd spruitje, dat in de Tahami zich ontlast, buitengewoon incrusteerende eigenschappen bezit ${ }^{172}$. Kalk is dus daarin aanwezig en moet ook ergens in het terrein, waardoor het riviertje vloeit, ontbloot liggen. - Wat Borneo en Java betreft, treden hier de kalkgesteenten - voor het grootste gedeelte, zoo niet uitsluitend, van tertiairen (eoceenen en mioceenen) ouderdom - in de strumadistricten meer op den voorgrond dan op Sumatra, hoewel op het eerstgenoemde eiland, Borneo, de kwaal ook voorkomt in streken, waar dergelijke gesteenten geheel ontbreken of uiterst zeldzaam zijn, gelijk in het dal van de Melawi en in het brongebied van de Sikajam.

Het is niet alleen uit het voorkomen van kalkgesteenten in den bodem, dat men de endemische struma heeft willen verklaren. Sommigen meenen, om weder met Hirsch te spreken, "dass es keineswegs auf die Grundmasse des Gesteins, sondern lediglich auf den Gehalt desselben an Magnesia ankomme, und dass das Maximum der Krankheitsfrequenz auf dolomitischem Boden angetroffen werde", ja beweren zelfs dat juist "aus dem Mangel, bez. dem sparsameren und selteneren Vorkommen von Magnesia in dem jüngeren jurassischen Gestein, der Kreide und den Tertiär-Formationen sich die Immunität der Gegenden erklärt, in welchen diese Boden-Verhältnisse prävaliren " 173 . In den Indischen Archipel komt echter, gelijk wij nog zooeven hebben doen uitkomen, struma juist het meeste voor op jongere,

171 Zie blz. 356 hierboven.

$171_{a}$ Zie blz. 391.

$171 b$ Ook in andere streken van de Lampongsehe Districten, onder anderen in het Zuidoosten bij Ketapan, worden, volgens Verbeek, deze kaolienachtige tuffen gevonden. Volgens de analyse nu van een monster afkomstig van deze streek, zouden in 100 deelen bevat zijn: kiezelzuur 69.68 en aluinaarde 17.8 ; verder 7.027 water, een weinig ijzeroxyde, mangaanoxyde, magnesia en kalk, natuurlijk in onbeteekenende hoeveelheid (Natuurkundig Tijdschrift voor Nederl. Indië, dl. XX, blz. 140 en 181 vlg.

172 Zie blz. 412 hierbeneden.

173 Hirseh, Handbuch der historisch-geographischen Pathologie, dl. I, ble. 121. 
tertiaire en kwartaire, vormingen, op gesteenten dus, die, volgens de gegeven voorstelling, weinig of geen magnesia zouden bevatten. In hoeverre dit in werkelijkheid het geval is, zou alleen door scheikundige analysen zijn uit te maken $\mathbf{1 7 3}_{\mathbf{a}}$. Zeker is het dat bepaalde dolomieten of dolomietachtige, magnesium-carbonat in eenigszins belangrijke hoeveelheid bevattende, kalksteenen, in de streken met endemische struma, zich nergens voordoen.

Even weinig als de voorgaande theorie, vinden wij in den Indischen Archipel de meening bevestigd, dat struma "nur in Gegenden mit metallführendem Gestein heimisch sind, dass ihr endemisches Vorherrschen wesentlich von der Anwesenheit von Schweifeleisen oder Kupferkies abhängig ist" 174. In geheel Zuid-Sumatra toch, waar struma meer dan elders op het eiland endemisch is, komen zoogoed als geen ertsen voor, en worden bepaaldelijk koper en ijzer niet gevonden $\mathbf{1 7 5}^{\mathbf{7 5}}$. In Midden- en in Noord-Sumatra worden beide metalen wel aangetroffen, doch niet in die mate en op die wijze, om de veelvuldige gevallen van struma daarmede in verband te brengen en daaruit te verklaren. Slechts zelden toch treden zij op in de nabijheid van de zetels der endemie. Met het koper is dit, voor zoover wij het hebben kunnen nagaan, alleen het geval in het strumagebied van Mandaïling, waar in de nabijheid van Moeara-Sipongi koperkies voorkomt ${ }^{\mathbf{1 7 6}}$. En wat bovendien het ijzer betreft, is het hoofdzakelijk als zuiver magneetijzer $\left(\mathrm{Fe}^{3} \mathrm{O}^{4}\right)$ en ijzerglans $\left(\mathrm{Fe}^{2} \mathrm{O}^{3}\right)$, dat het erts zich voordoet, en niet, waarop het bepaaldelijk schijnt aan te komen, als zwavelijzer 177. Ook op Borneo is de

173a Eruptieve gesteenten, zoowel oudere als jongere, bevatten altijd magnesia, in zeer uiteenloopende hoeveelheden. Zoo varieert, gelijk uit eenige scheikundige analysen gebleken is, het gehalte aan Mg.O., van de granieten van Sumatra, van 0.44 tot 6.50 , van de diabazen, $\operatorname{van} 2,90$ tot 19.02 , en, van de jong-tertiaire, kwartaire en recente vulkanische gesteenten, van 0.20 tot 8.27 (Verbeek, Topographische en geologische beschrijving van een gedeelte van Sumatra's Westkust, blz. $232-233,310-311$ en 516-517).

174 Hirsch, O. c., blz. 122.

175 Verbeek, Topographische en geologische beschrijving van Zuid-Sumatra, Jaarboek van het Mijnwezen in Nederlandsch Oost-Indië, jaarg. 1881, dl. I, blz. 211 vlg.

176 Fennema, Topographische en geologisohe beschrijving van het Noordelijk gedeelte van het Gouvernement Sumatra's Westkust, Jaarboek van het Mijnwezen in Nederlandsoh Oust-Indië, jaarg. 1887, Wetenschappelijk gedeelte, blz. 249.

1 7. Verbeek, Topographische en geologische beschrijving van een gedeelte van Sumatra's Westkust, blz. 562 vv. Alleen hier en dasr heeft het ijzererts een gering zwavelgehalte (Verbeek, O. c., blz. 565). 
aanwezigheid van ijzer en koper niet van dien aard, dat daarin een aetiologisch moment mag worden gezocht ${ }^{\mathbf{1 7 8}}$, terwijl op Java, gelijk bekend is, de bodem zoogoed als geen metalen bevat.

Eene andere, zeer algemeen verbreide, meening is dat de oorzaak van de struma in het drinkwater is te zoeken. Ook ten aanzien van de endemische struma in den Indischen Archipel heerscht deze meening. In de eerste plaats, gelijk wij in het volgende hoofdstuk zullen zien 179, bij de inlandsche bevolking-zelve. Doch verder is ook door eenige berichtgevers op het gebruik van minder goed of van bijzonder drinkwater in de streken, waar struma voorkomt, uitdrukkelijk gewezen en daaraan de kwaal toegeschreven. Zoo zegt, om hier eenige voorbeelden te citeeren, Von Rosenberg van de Papuwa's van Hattam bij de Dorei-baai op Nieuw-Guinea: "De bewoners der hoog in het gebergte, ver van loopend water, gelegen dorpen of huizen verzamelen in den morgenstond groote bundels eener mossoort waarmede de boomen en struiken dik bezet zijn, en die de eigenschap heeft, de vochtigheid in den dampkring in hooge mate op te slorpen. Dit mos wordt vervolgens uitgeperst, en het daaruit verkregen vocht tot drinkwater gebruikt". Volgens Von Rosenberg zou dat de reden zijn, waarom zoovele dezer bergbewoners kroppen hebben ${ }^{180}$. In het district DoesoenTimor, in het strumagebied van de Beneden-Barito op Borneo, laat het drinkwater ook veel te wenschen over. Waar de Heer Bangert over de vele kroplijders in het dorp Sangarwasi spreekt 1 ${ }^{\mathbf{3}}$, vermeldt hij ook dat de bewoners het water plegen te gebruiken van eene beek, die door eenige moerassen gevoed wordt 182. In den drogen tijd heerscht er door het geheele district gebrek aan drinkwater. Vooral op de hooger gelegen plekken is dit het geval, en zijn de inlanders daar genoodzaakt, putten te graven ten einde het regenwater daarin te verzamelen ${ }^{183}$. Gebrek aan goed drinkwater doet zich ook voor op het plateau van Makakau, in het strumagebied van Zuid-Sumatra, op de plaatsen althans van de rivieren

178 Posewitz, Borneo, blz. 330 vv. en 338 vv.

179 Zie blz. 420 vgl. hierbeneden.

180 Von Rosenberg, Reistochten naar de Geelvinkbaai, blz. 104.

181 Zie blz. 367 vgl. hierboven.

182 Bangert, Verslag der reis in de binnenwarts gelegen streken van DoesoenIlir, Tijdschr. v. Ind. T. L. en Vk., dl. IX, blz. 165.

183 Schwaner, Borneo, dl. I, blz. 93. 
verwijderd. De bewoners dezer plaatsen zijn dan ook gedwongen, "de scheuren, kloven of kleine dalen af te dammen en het regenwater daarin te verzamelen, hetgeen tot huiselijk gebruik alsook tot baden dient». Dit water, op zichzelf onzuiver, is bovendien, gelijk het water van de kleine rivierspruitjes, "met scherpe kalkachtige stoffen bezwangerd", waaraan de vele kropgezwellen, welke hier zich voordoen, worden toegeschreven ${ }^{184}$. - In hetzelfde strumagebied liggen, in het Toelang-Bawangsche, volgens den Officier van Gezondheid Wienecke, de dorpen met endemische struma aan "rivieren welke vele kalkzouten bevatten, terwijl men ook putwater gebruikt, dat deze bijmengselen bezit” 185. Ook Francis brengt het voorkomen van struma, in dit gedeelte van Sumatra, in verband met het water. Als een der zetels van de endemie wordt door hem, gelijk wij gezien hebben $\mathbf{1 8 6}$, het dorp Teti-Samang genoemd, gelegen ter plaatse waar een spruitje zich in de Tahami ontlast. "Men zegt", aldus schrijft hij, "dat het water van dit spruitje het vermogen bezit, om de kleinste boomwortels, die in hetzelve neergroeien, binnen zeer korten tijd tot eene verbazende dikte te doen zwellen" ${ }^{187}$. De voor de hand liggende verklaring van dit verschijnsel is zeker, dat het water vele vaste stoffen, koolzuur ijzeroxydule bij voorbeeld, doch waarschijnlijker koolzure kalk, in opgelosten toestand bevat, en dus incrusteerende eigenschappen bezit, de voorwerpen, die zich daarin bevinden, met eene kalkkorst overdekt, schijnbaar dus doet zwellen. - Eindelijk willen wij er nog op wijzen, hoe ook de Officier van Gezondheid Kervel de endemische kropgezwellen in het PadangPandjangsche wil toeschrijven aan het drinkwater, dat moeielijk oplosbare zouten zou bevatten $\mathbf{1 8 \mathbf { 8 }}$.

Wij behoeven bij deze verschillende verklaringen omtrent het ontstaan van struma, door het gebruik van bepaalde wateren, niet lang stil te staan. De waarde daarvan kan moeielijk beoordeeld worden, zoolang niet door een nauwkeurig onderzoek is uitgemaakt, welke vreemde, organische of anorganische, bestanddeelen zich in die

\footnotetext{
184 Tijdsohrift voor Nederlandsch Indië, jaarg. 1857, dl. I, blz. 30 en 31.

185 Wienecke, Geneeskundig topographische schets van Telok-Betong en Onderhoorigheden, Geneeskundig tijdschrift voor Nederlandsch Indië, dl. IV, blz. 657 .

186 Zie blz. 356 hierboven.

181 Francis, Herinneringen uit den levensloop van een Indisch Ambtenaar, dl. I, blz. 215 , noot 1 .

188 Geneeskundig Tijdschrift voor Nederlandsch Indië, dl. IV, blz. 914.
} 
wateren bevinden $18 \mathbf{8}$. Echter kan het opgemerkt worden, dat de aanwezigheid van kalkzouten daarin, niet als oorzaak van de kwaal mag worden beschouwd. De waarneming toch heeft geleerd, gelijk door Hirsch met voorbeelden uitvoerig is aangetoond 190 , dat vele streken, waar in het drinkwater werkelijk kalkverbindingen overvloedig voorkomen, volstrekt kropvrij zijn, terwijl in andere, waar in het water in het geheel geen of slechts weinig kalk gevouden is, de kwaal algemeen heerscht.

$\mathrm{Er}$ is nog eene verklaring, die vaak, vooral met betrekking tot den Indischen Archipel, van het ontstaan van de endemische struma gegeven is. Velen willen de kwaal namelijk toeschrijven aan de wijzen, waarop men lasten pleegt te dragen. Men doet dit op het hoofd, op den rug of op den schouder, met behulp van eenen draagstok. De twee eerste wijzen zijn de meest gewilde. Op Bali zijn, volgens Dr. Jacobs, mannen en vrouwen gewoon, zware lasten op het hoofd te vervoeren 191. Bij de Bataks en de Menangkabawsche Maleiers van de Padangsche Bovenlanden wordt ook op deze wijze gedragen 192 . Om den last minder pijnlijk te doen drukken, legt men, bij de laatstgenoemden, veelal een opgerolden doek of eenen ring van droog gras of van bladeren op het-hoofd; meer nog makt men gebruik van de zoogenaamde kulipè, een krukje waardoor het gewicht van den last over hoofd en schouders verdeeld wordt 193. Naast het dragen op het hoofd, heeft men ook in de

189 Hetgeen echter de onderzoekingen elders geleerd heeft doet de onhoudbaarheid van de drinkwater-theorie voor de struma-genese inzien, daar gelijk Hirsch opmerkt, "es trotz aller darauf hingerichteter Untersuchungen bisher nicht gelungen ist, in den suspecten Kropfbrunnen oder Kropfquellen irgend ein constantes, allen gemeinsames, eben nur ihnen zukommendes, für sie also characteristisches Etwas mineralischer oder organischer Natur nachzuweisen" (Hirsch, Handbuch der historisoh-geographischen Pathologie, dl. II, blz. 130 vlg.).

190 Hirsoh, O. c., blz. 131 vlg.

191 Jacobs, Eenigen tijd onder de Baliërs, blz. 23 vlg.

192 Bij de Bataks van de binnenlanden van Deli en Serdang zijn het vooral de vrouwen, die op het hoofd dragen, terwijl de mannen van den draagstok gebruik maken (zie: Katalog der Batakkersammlung von G. Meissner, Gruppe D, blz. 5 vv., N9. 30,38 en 44$)$.

193 Van Hasselt, Volksbeschrijving van Midden-Sumatra, blz. 367. De kulipe, waarvan men eene afbeelding vindt op Plaat LXX fig. 5 van den bij dit werk behoorenden Ethnographischen Atlas, bestaat uit een krukje of bankje van hout, dat op den schouder rust. Op de kruk is een hoefijzervormig gebogen rotan bevestigd, die met een stuk mat is overtrokken, waarin men droge ilalang of idjuk gestopt heeft. Het aldus gevormde kussen drukt op het hoofd. De vracht wordt 
Padangsche Bovenlanden, doch meer uitsluitend geheel in het Zuiden, in de XII Kota, het dragen op den rug. Daartoe worden de goederen in lichte manden gepakt, of wel men bindt ze op een raam van bamboe, waaraan evenals aan den mand, drie zeelen van tot doek geklopte boomschors zijn bevestigd. Een daarvan rust tegen het voorhoofd van den drager, die door de beide zijdelingsche de armen steekt 194 . - Deze wijze om lasten te vervoeren in het een of ander toestel, dat door middel van twee schouderriemen als een ransel tegen den rug hangt, doch ook tevens gesteund wordt door een band over het voorhoofd, vindt men verder bij de bewoners van Rantau-di-baroew, Djambi, Korintji, Rawas en Redjang, en verder bij de Orang-Talang 195. Het is duidelijk dat bij deze manier van dragen, waarbij men het lichaam min of meer voorover gebogen houdt, het gewicht van den last in de eerste plaats op den rug en de schouders, doch voor een deel ook op het hoofd drukt. Dit laatste is natuurlijk nog meer het geval, wanneer, zooals wel eens gebeurt, de schouderriemen ontbreken, en de vracht alleen aan den voorhoofdsband hangt. Zoo naar het schijnt in Serampei. "The people of this country", lezen wij bij Marsden, "are accustomed to carry burthens of from sixty to ninety pounds weight, on journeys that take them twenty or thirty days; and it astonishes a low-lander to see with what ease they walk over these hills, generally going a shuffling or ambling pace. Their loads are placed in a long, triangular basket, supported by a fillet across the forehead, resting upon the back and back part of the head, the broadest end of the triangle being uppermost, considerably above the head, and the small end coming down as low as the loins" 196. Ook Dr. Wyckerheld Bisdom maakt, sprekende van deze manier van dragen bij de bewoners van Semendo, geen gewag van schouderriemen ${ }^{197}$. Evenmin doet de Heer Wesly dit ten aanzien van de

op de kulipè geplaatst, en de rechter- of linkerhand, al naar gelang men rechts of links draagt, houdt den voorsten stijl van het krukje vast (Zie de verklaring der platen, blz. 28).

194 Van Hasselt, O. c., blz. 367. Zie ook de afbeeldingen op Plaat IV fig. 1 en LXXIV fig. 1 van den Ethnographisohen Atlas, met de daarbij behoorende verklaringen op blz. 2 en 30 .

105 Van Hasselt, O. e., blz. 367. Voor de Orang-Talang, zie: Tocht naar het rijk van Poeloe-Lawan, door een oud-ambtenaar van het Mijnwezen, Tijdschrift voor het Binnenlandseh Bestuur, dl. III, blz. 141-142.

196 Marsden, History of Sumatra, blz. 320.

107 Zie blz. 417 hierbeneden. 
Rawasers. De mand, zegt hij, wordt bevestigd aan eenen band over. het voorhoofd, dat alzoo de geheele 198 drukking van den last ondervindt 199 . - Op Borneo komt deze wijze, om lasten te transporteeren, eveneens voor. Allereerst bij de Dajaks van het stroomgebied der Kapoeas. Zij dragen, vermeldt de Kolonel Gerlach, in de beschrijving eener door hem in dit gebied gedane reis, op den rug. Daartoe hebben zij eene langwerpige, van rotan gevlochten, mand, die aan de voorzijde geheel open is; er zijn twee draagbanden aan bevestigd, die over de schouders en onder de armen doorgaan, en dan nog een band, die langs het voorhoofd gaat. De mannen dragen op die wijze met het meeste gemak uren ver vrachten van 40 kilo, de vrouwen de helft 200 . Ook in het stroomgebied van de Barito, bepaaldelijk in het district Doesoen-Timor, worden lasten gedragen op den rug "an einem Stirnband, mit Beihilfe von Schulterriemen" 201. Hetzelfde gebeurt ook bij de Orang-Bukit van het Meratoes-gebergte ${ }^{202}$. Evenals op Sumatra, schijnen de schouderriemen aan het toestel, dat op den rug gedragen wordt, wel eens te ontbreken. Zoo zegt de Heer Van Lynden van

198 Wij cursiveeren.

190 Wesly, De onderafdeeling Rawas, Tijdschrift voor het Binnenlandsoh Bestuur, dl. III, blz. 306. Zie ook : Ethnographische Atlas van Midden-Sumatra, Plaat IV fig. 2, waar, volgens de verklaring der platen (blz. 2), een jongen van Sceroelangoen (Rawas) is afgebeeld met eene mand op den rug, alleen door eenen voorhoofdsband bevestigd. - In de Lampongsche Districten, zegt Zollinger, wordt alles op den rug gedragen, waar het slechts eenigszins mogelijk is. Lange korven, die naar beneden enger worden, gebruikt men om kleiner voorwerpen op den rug te dragen, terwijl groote pakken eveneens zoo gebonden worden, dat men ze op den rug kan nemen (Zollinger, De Lampongsohe Districten, Tijdschrift voor Nederl. Indië, jaarg. 1847, dl. I, bl. 129). Hce de vracht bevestigd wordt, vinden wij echter niet vermeld. 200 Gerlach, Reis naar het meergebied van den Kapceas, Bijdragen tot de T. L. en Vk. v. Nederl. Indië, 4e volgreeks, dl. V, blz. 312.

201 Grabowsky, Der Distrikt Dusson-Timor in Sudost-Borneo und seine Bewohner, Ausland, jaarg. 1884 , blz. 448.

202 Grabowsky, Die Orang-Bukit oder Bergmenschen von Mindai in SüdostBorneo, Ausland, jaarg. 1885, blz. 785. Zie ook: Book, The head-hunters of Borneo, waar, op Plaat XXVI fig. 1, een Orang-Bukit is afgebeeld met eenen last. op den rug, bevestigd aan eenen voorhoofdsband en twee schouderriemen. - De Bandjareezen, zegt Sal. Müller, maken voor het vervoeren van rijst, vruchten, enz., algemeen gebruik van korven, die op den rug gedragen worden (Sal, Miiller, Reizen en onderzoekíngen in den Indischen Arohipel, dl. I, blz. 26\%). In de onderafdeeling Tabalong en Kloewa worden eveneens vrachten en gewone of kleine manden op den rug vervoerd (Masthoff, Aanteekeningen omtrent de onderafdeeling Tabalong en Kloewa, Indische Gids, jaarg. 1888, dl. I, blz. 237). Hoe eohter de mand bevestigd wordt, vinden wij niet vermeld. 
de Dajaks van het stroomgebied der Melawi: "Te land worden de goederen vervoerd in manden, welke door eenen band voor het voorhoofd gedragen of als een ransel met de schouders gehouden worden" 203 . Verder hebben wij de aandacht te vestigen op eene mededeeling van Prof. Veth. Sprekende van de heerediensten, welke de Dajak te praesteeren heeft, merkt hij op, dat die vooral te pas komen, wanneer de Maleische hoofden hun district bezoeken: zij laten zich dan dragen in een lichten bamboezen stoel, die tegen den rug des dragers steunt en met eenen band om zijn hoofd wordt vastgehouden ${ }^{204}$. - Eindelijk zien wij, hoe, in Centraal-Celebes, de vrouwen manden op den rug plegen te dragen, door middel van eenen steunband over het voorhoofd 205 .

Uit de twee hier beschreven wijzen om lasten te dragen, namelijk op het hoofd of op den rug, in een toestel hangende, met of zonder behulp van schouderriemen, aan eenen voorhoofdsband, hebben vele berichtgevers de endemische kropgezwellen in den Indischen Archipel willen verklaren ${ }^{206}$. Meer in het bijzonder hebben dit laatstelijk de Heeren Jacobs en Wyckerheld Bisdom gedaan. Beiden brengen daarbij nog een ander aetiologisch moment in rekening, namelijk het veelvuldig beklimmen van bergen. Ziehier hetgeen Dr. Jacobs, sprekende van de Balineezen, daaromtrent opmerkt: "Hoe hooger men eenen berg beklimt, des te steiler wordt de weg; dit geldt zeker voor de meeste, zoo niet voor alle bergen. Is de weg in het begin zacht glooiend, zoodat men ternauwernood bespeurt, dat men klimt, langzamerhand neemt de helling toe. Dat het klimmen het loopen bemoeielijkt, weet ieder, die zelfs met physica en physiologie onbekend is, bij ondervinding. Ook is het ieder, die ooit eenen berg of eene steilte beklom, bekend, hoe door dit klimmen, al geschiedt het nog zoo langzaam, de hartactie wordt versterkt, de hartkloppingen worden vermeerderd en de ademhaling wordt versneld, zoodat in dezelfde tijdseenheid

203 Van Lynden, Aanteekeningen over de landen van het stroomgebied der Kapoeas, Natuurkundig Tijdschrift v. Nederl. Indië, dl: II, blz. 581.

204 Veth, Borneo's Wester-Afdeeling, dl. II, blz. 336-337, waar ook, op Plaat II fig. 1, eene afbeelding voorkomt van zulk eenen draagstoel.

205 Riedel, De oorspronkelijke volksstammen van Centraal-Celebes, Bijdragen tot de T. L. en Vk. van Nederl. Indië, 5e volgreeks, dl. I, blz. 81.

206 Zoo de officieren van Gezondheid Kervel, Buning en Neeb, de Heeren Wesly en Grabowsky, en de berichtgever van de endemische struma bij de Orang-Talang. Ook de Heer Van Hasselt vestigt, waar hij van het veelvuldig voorkomen van struma bij de Menangkawsche Maleiers spreekt, op die twee wijzen om lasten te dragen, de aandacht. 
meer bloed door het hart naar de vaten wordt gestuwd. In gewone omstandigheden zal het evenwicht door de afvoerende vaten spoedig weer worden hersteld. Doch hier komt een ander feit bij, dat juist dien geregelden afvoer in den weg staat. De Baliër, vooral de Balische vrouw, is gewoon om soms zeer zware vrachten op het hoofd te dragen 207 . Ik behoef hier niet in herinnering te brengen, welke halsspieren hierbij in actie worden gebracht. Dat eene bijna aanhoudende drukking der gespannen, zich allengs sterk ontwikkelende halsspieren op de onderliggende afvoerende vaten eene continueerende veneuse stasis in de zeer vaatrijke glandula thyreoidea zal bewerken, lijdt, dunkt mij, evenmin twijfel, als dat daardoor langzamerhand de vaten der klier zich blijvend zullen verwijden, misschien zelfs het klierweefsel en het tusschenliggend stroma zullen hypertrophieeren. Ik hecht dan ook veel gewicht aan het feit, dat onder de Banglische kroplijders alleen de vasculeuze vorm van struma ten minste praedomineert, en ik vermoed dat wel alle gevallen van endemisch kropgezel onder dezen vorm zullen gerangschikt kunnen worden" ${ }^{208}$. Ongeveer hetzelffe zegt Dr. Wyckerheld Bisdom, ter verklaring van de struma-endemie in Semendo. "Vooral de vrouwen", aldus lezen wij, "moeten vele en zware lasten dragen in eenen korf op den rug, welke korf met eenen band om het voorhoofd wordt vastgebonden, terwijl de last dikwijls boven het hoofd uitsteekt; daardoor loopen de draagsters met gebogen rug voorover en spannen sterk de buigspieren van het hoofd, hetgeen eene drukking moet uitoefenen op de oppervlakkige, misschien ook op de dieper gelegen venae en arteriae van den hals, en aangezien, door de lengte van het beenig kanaal der art. carotis, de glandula thyreoidea als het ware een reservoir vormt voor het bloed, dat den schedel niet kan binnendringen, zoo is de struma ongedwongen verklaard bij deze vrouwen.

207 "En ik meen", laat Dr. Jacobs hierop volgen, "op physische gronden te mogen beweren, dat dit de meeste, zoo niet alle, bergbewoners zullen doen, wijl zij, door den last in de lengteas van het lichaam te brengen, het klimmen zich niet zoo zullen bemoeielijken als wanneer zij dien bij voorbeeld op den rug torschen". Dat dit in den Indischen Archipel niet het geval is, kan uit het hiervoren medegedeelde gebleken zijn: op Sumatra en op Borneo wordt meer op den rug dan op het hoofd gedragen. Zie ook noot 213 en 214 hierbeneden. Het dragen op den rug is zeker verreweg practischer, al was het alleen omdat men de handen daarbij geheel vrij heeft, hetgeen wel noodig is bij het trekken door wildernissen of het gaan langs steile paden. Zie onderen anderen: Reizen in Midden-Sumatra door de leden der Sumatra-expeditie, dl. I, blz. 63.

208 Jacobs, Eenigen tijd onder de Baliërs, blz. 23 vlg. 
Immers men ziet zelfs kleine meisjes op die wijze lasten dragen, terwijl het bergachtig terrein den bloedsaandrang bevordert" 209 .

De vraag is: in hoeverre voldoet de hier door Dr. Jacobs en Dr. Wyckerheld Bisdom verkondigde theorie - de juistheid waarvan ik, als leek op het gebied der medische wetenschappen, overigens niet beoordeelen kan - ook voor de overige streken van den Indischen Archipel, waar struma endemisch heerscht? En dan verdient het opmerking, dat de twee aetiologische momenten, het dragen van lasten op eene wijze, dat het gewicht daarvan geheel of ten deele op het hoofd drukt, en het veelvuldig beklimmen van bergen, in vele van die streken aanwezig zijn. Intusschen zijn er ook plaatsen, zetels der endemie, waar dit niet het geval is. Zoo zien wij hoe op Java struma juist het meest voorkomt op de vlakte van Kediri en van Jogjåkartå, terwijl mannen noch vrouwen hier, volgens de verklaringen van de Heeren De Vogel, Neeb en Groneman, gewoon zijn op het hoofd te dragen, doch dit doen, de eersten, op de schouders aan eenen draagstok, de laatsten, op den rug of op de rechterheup in de over den linkerschouder geslagen slèndang 210. Hier voldoet de theorie dus niet. Men zou echter te ver gaan, haar alleen daarom te verwerpen. Hetgeen onzes inziens dan ook meer tegen haar pleit, waar zij moet strekken tot verklaring van de endemische struma 211 , is dat zij aan hetzelfde euvel mank gaat, als waarom Hirsch zoovele andere daaromtrent gemaakte hypothesen onaannemelijk acht. "Jede Speculation", merkt hij op, "über die Ursachen des endemischen Kropfes ist als eine absolut verfehlte anzu-

209 Wyckerheld Bisdom, Een en ander bij struma, Geneeskundig Tijdschrift voor Nederlandsch Indië, dl. XXIX, blz. 525 vlg. - De schrijver wijst nog t. a. p. op de gewoonte der jonge meisjes om vele, en daaronder zeer zware, zilveren halsbanden te dragen, waardoor eene drukking op de oppervlakkige bloedvaten aan de nekzijde wordt uitgeoefend.

210 De slèndang is, gelijk men weet, een lange smalle doek, die over een der schouders naar de tegenovergestelde zijde des lichaams gedragen wordt.

211 Zie: Hirsch, Handbuch der historisch-geographischen Pathologie, blz. 126, waar het heet: "Dass in der hier erörterten Weise (namelijk langs zuiver mechanischen weg, door het dragen van zware lasten bij voorbeeld) hyperämische Schwellung der Sohilddrüse mit Erweiterung der Gefässe und die sich eventuell daraus entwickelnden anderweitigen Veränderungen des Organs (Hypertrophie u. a.), d. h. Kropfbildung zu Stande kommen kann, und höchst wahrscheinlich in manchen Fällen auch in der That zu Stande kommt, oder dass dadurch zum mindesten eine prädisponirende Ursache für die Kropf-Genese gegeben ist, lässt sich a priori nicht bestreiten, eine Erklärung für das endemische Vorkommen der Krankheit kann darin doch aber rationeller Weise nicht gefunden werden". 
sehen, welche den Umstand ausser Augen lässt, dass diese Krankheit den ausgesprochenen Character eines Local-Iseidens, und zwar eines auf ganz enge Kreise beschränkten Local-Leidens trägt, und welche, ohne Berücksichtigung dieses Umstandes, solche Einflüsse als Krankheitsfactoren geltend macht, die - sit venia verbo - kosmopolitischer Natur sind" 212. Wanneer de hier besproken theorie juist was, dan zou ook in den Indischen Archipel de endemische struma eene grooter verbreiding hebben, want de gewoonte, om lasten op het hoofd te torschen, is er vrij algemeen $\mathbf{2 1 3}$, en bergstreken en geaccidenteerde terreinen vindt men op de verschillende eilanden meer dan vlakke landen. De Minahasa, om slechts een voorbeeld te citeeren, zou op die wijze zeer strumarijk zijn, terwijl de kwaal zich daar nu niet meer dan zeer sporadisch voordoet 214.

III.

Wij stellen ons voor, in dit hoofdstuk, de struma uit een ethno-

212 Hirsch, O. c., blz. 126-127.

213 Over het algemeen wordt er, gelijk wij reeds opmerkten, meer op het hoofd, doch vooral op den rug gedragen, dan op de schouders. Het geaccidenteerde terrein en de smalle paden leenen zich dan ook minder voor de laatste wijze om goederen te vervoeren. Opmerking verdient het, dat sommige volken van het dragen op de schouders een bepaalden afkeer hebben. Zoo de Dajaks van het stroomgebied der Barito. Een zwaren last zullen zij liever op de hierboven beschreven wijze op den rug, dan een lichten op den schouder nemen. Bij gelegenheid dat er eens veel zieken onder de dwangarbeiders waren, deelt de Kolonel Gerlach mede, veroorzaakte dit groote moeielijkheid bij het overbrengen van hen, die geevacueerd moesten worden en daarvoor werden gelegd in brancards, elk voor twee dragers bestemd. De Dajaks vonden er niets in, zich eenen stoel op den rug te laten binden, waarop de patient zich kon nederzetten, doch weigerden halsstarrig om met hun tweeën een brancard te dragen, omdat zij zeker waren, zooals zij zeiden, dat zij hunnen last eenige malen zouden laten vallen. Moeten er kisten getransporteerd worden, die te zwaar zijn voor 6́́n man, dan slaan zij ze eenvoudig open en verdeelen den inhoud in éénmansvrachten (Gerlach, Reis naar het meergebied van den Kapoeas in Borneo's Wester-Afdeeling, Bijdragen tot de T. L. en Vk. van Nederl. Indië, vierde volgreeks, dl. V, blz. $312-313)$. Ook de Bolaäng-Mongondouer op Noord-Celebes draagt op den rug in een sangkole, eene mand van 3 voet lengte en 1 a $1 \frac{1}{2}$ voet breedte, en zal niet licht van deze gewoonte afwijken (N. Ph. Wilken en J. A. Schwartz, Verhaal eener reis naar Bolaäng-Mongondou; Mededeelingen v. w. h. Nederl. Zendelinggenootschap, dl. $\mathrm{XI}$, blz. 225-226).

214 In de Minahasa wordt op den rug gedragen in eene sangkole, als in BolaängMongondou (zie de voorgaande noot), en op het hoofd. Vooral de vrouwen zijn gewoon, zware lasten op de lastste wijze te torschen. Bijna dagelijks kan men ze, met goed gevulde manden op het hoofd, den weg van de tuinen naar de negerij of het dorp, hoogte op, hoogte af, zien maken. 
graphisch oogpunt te beschouwen, bepaaldelijk na te gaan, welke de voorstellingen 'zijn van den inlander omtrent het ontstaan van de kwaal en welke middelen daartegen door hem worden aangewend.

Vrij algemeen verbreid onder den inlander is de meening, dat de oorzaak van de struma in het drinkwater te zoeken is. Zoo zegt de Heer Van Rees, gelijk wij reeds in het eerste hoofdstuk gezien hebben, dat de Redjangers beweren, dat kropgezwellen een gevolg zijn van het drinken van water uit kleine stroomen en leidingen, welke langs de ladangs loopen, want dat zij, die langs de Moesi wonen en uitsluitend van het zuivere rivierwater gebruik maken, van de kwaal bevrijd blijven ${ }^{215}$. Dezelfde meening vindt men in Semendo. Zij, die de op de heuvelen gelegen rijstvelden en koffietuinen bewerken en daar veelal blijven wonen, drinken van het water, dat uit den grond opborrelt, hetgeen door de meeste lijders als oorzaak van de struma wordt beschouwd 216. In de Ophirdistricten, om hier nog eenige voorbeelden aan te hạlen, gelooft men, volgens eene mij door den Heer Visser gedane mededeeling, eveneens dat de kropgezwellen door het drinkwater veroorzaakt worden, terwijl in Pasemah "the natives themselves attribute goitre to drinking the water of some particular stream" 217. Bij de Bataks van het Pane- en Bila-stroomgebied wordt wel eens beweerd, dat het gebruik van water, hetwelk in beroering is geweest met de tabulumbung, eene wilde meloensoort, struma doet ontstaan 218. Op Borneo, bepaaldelijk in Tanah-Laoet, schrijft de inlander de kwaal toe aan het gebruik van rivierwater, dat over eene steensoort, batutekok geheeten, vloeit 219 . Ook op Java worden sommige wateren gezegd krop te veroorzaken. Het geloof bestaat echter, zooals de Assistent-Resident De Vogel mij mededeelde, dat dit alleen het geval is bij gebruik van dergelijke wateren op bepaalde dagen van de gecombineerde pasar- en gewone week 220 . Uitdrukkelijk vinden

215 Zie blz. 351 hierboven.

216 Zie blz. 353 hierboven.

217 Presgrave, Account of a journey from Manna to Pasummah-Lebar and the ascent of Gunung-Dempo, Journal of the Indian Archipelago, New series, dl. II, blz. 10 .

218 Neumann, Het Pane- en Bila-stroomgebied, Tijdschr. v. h. Nederl. Aardrijkskundig Genootschap, 2e serie, dl. III, blz. 221.

219 Lokhorst, Schets eener geneeskundige plaatsbeschrijving der afdeeling TanahLaut, Geneeskundig Tijdsohrift v. Nederl. Indië, dl. X, blz. 239.

220 Gelijk bekend is, hebben de Javanen, naast de gewone week van zeven dagen, die verbasterd Arabische of verbasterd Indische namen dragen, nog eene 
wij dit van de Alas-Loedåjă, in het Zuiden van Kediri, vermeld. Daar zou zich een riviertje bevinden, dat uit den mond van een beeld met eenen krop te voorschijn komt. Zij, die van het water daarvan op Vrijdagen Donderdag-Kliwon drinken, krijgen onvermijdelijk kroppen 221.

Andere oorzaken, waaraan de inlanders het ontstaan van de struma toeschrijven, verdienen hier nog vermeld te worden. "The natives themselves (van Belalau) ascribe it to the soil, but why they could not say" 222. In Semendo beweren sommige inlanders, dat in het water een worm voorkomt, die, bij het wasschen van het aangezicht, door de neusgaten in de keel geraakt, en zoo struma veroorzaakt, terwijl anderen daarentegen de kwaal toeschrijven aan het eten van veel water bevattende bladgroenten ${ }^{223}$. Volgens den Alfoer van Boeroe, zouden de gezwellen ontstaan door het veelvuldig beklimmen van bergen 224. Niet zelden wordt de kwaal beschouwd als door overerving te zijn verkregen. Het geloof dat de struma overerfelijk is, vindt men toch bij verschillende volken van den Indischen Archipel, gelijk uit het in het eerste hoofdstuk medegedeelde kan zijn gebleken, als bij de Maleiers in het Zuidelijke dee] van de Padangsche Bovenlanden en in het gebied van de Djoedjoean, de Bataks en de Dajaks in de Wester-Afdeeling van Borneo 225. - Overigens behoeft het nauwelijks te worden gezegd, dat het ontstaan van kropgezwellen ook wel eens aan bovenatuurlijke oorzaken wordt toegeschreven. Zoo behoort tot deze volks-aetiologie het zooeven vermelde geloof bij de Javanen, dat dẻ kropveroorzakende eigenschappen, die aan sommige wateren worden toegeschreven, zich alleen op bepaalde dagen van de gecombineerde gewone en pasar-week openbaren. Bij de Menangkabawsche Maleiers in het Zuidelijke gedeelte van de Padangsche Bovenlanden weet men, volgens den Heer De Rooy, te vertellen van personen, die door het baden in eene

zoogenaamde pasar- of marktweek van vijf dagen, waarnaar de marktbeurten in zekere kringen van naburige plaatsen berekend worden. De dagen dezer marktweek heeten: pahing, pon, wage, kliwon en legi. De naam van elken dag is uit den naam van den dag der gewone week en dien der pasarweek samengesteld, bij voorbeeld: zondag-pahing, maandag-pon, dinsdag-wage, enz. Aan sommige van die combinaties wordt eene bijgeloovige beteekenis gehecht, een gelukaanbrengend of onheilverwekkend vermogen toegekend.

221 Zie: Winter, Javaansche samenspraken, blz. 168.

222 Forbes, A naturalist's wanderings in the Eastern Archipelago, blz. 171.

223 Wyokerheld Bisdom, Een en ander bij struma, Geneeskundig Tijdschrift voor Nederlandsoh Indië, dl. XXIX, blz. 525.

224 Zie blz. 380 hierboven.

225 Zie blz. $360,361,365$ en 370 hierboven. 
bron, onder eenen boom die săti, dat is met bovennatuurlijke macht begaafd, is, kropgezwellen zouden hebben bekomen. Op Beli wordt de kwaal toegeschreven aan eene bijzondere godheid, die gevestigd is in het gebergte bij het dorp Bangkala, en daarnaar Dewa-ajuBangkala genoemd wordt 226.

Ten aanzien van hetgeen wij in de tweede plaats wenschen na te gaan, de middelen die gebruikt worden tegen de struma, kunnen wij kort zijn. Somtijds tracht men door bezweringen de kwaal te keeren. Zoodra zich bij voorbeeld, op Bali, bij iemand het begin van een gezwel openbaart, wordt hij door de gezamenlijke dorpsbewoners bij fakkellicht naar de naastbijzijnde rivier gebracht, waar dan de balians of shamanen, onder aanroeping van alle geesten, de booze Dewaaju-Bangkala trachten uit te drijven ${ }^{227}$. Het is slechts bij uitzondering, dat men door de inlanders meer rationeele middelen tegen de kwaal ziet aanwenden. Hiertoe behoort het gebruik van het water van eenige minerale bronnen. In de eerste plaats herinneren wij aan het hierboven medegedeelde omtrent de Redjangers, die het aan de geneeskrachtige werking van het water van de Ajer-Poétih en van de in de nabijheid daarvan gelegen heete bronnen willen toeschrijven, dat de dorpen langs deze rivier gelegen vrij van struma zijn 228 . In Semendo beschouwen de inlanders de dampen, die uit eenige, zich in dat landschap bevindende, warme bronnen opstijgen, als bijzonder heilzaam tegen struma. Onderscheidene voorbeelden zouden er bestaan van radicale genezing van de kwaal bij aanwending dezer dampen 229 . Ook op Borneo, bepaaldelijk in de WesterAfdeeling in het gebied van de Sipaoek-rivier, worden er, gelijk wij hierboven reeds terloops vermeldden 230 , minerale wateren gevonden, die de inlanders tegen den krop plegen te bezigen 231. De gissing ligt voor de hand, dat het therapeutisch bestanddeel in deze wateren het jodium is. De Officier van Gezondheid Lindman

226 Jacobs, Eenigen tijd onder de Baliërs, blz. 13; Van Eck, Schetsen van het eiland Bali, blz. 403.

227 Van Eok, t. a. p. Zie ook: Jacobs, O. c., blz. 26.

228 Zie blz. 351 hierboven, en het daar geciteerde Natuurkundig Tijdschrift vior Nederlandsch Indië, dl. XXIII, blz. 69.

229 Maier, Scheikundig onderzoek van eenige minerale bronnen, afkomstig uit het landschap Semendo, Natuurkundig Tijdschrift v. Nederl. Indië, dl. XXX, blz. $37-38$.

230 Zie blz. 371 hierboven.

231 Bleekrode, Scheikundig onderzoek van bronwater van Sepauk, Geneeskundig Tijdschrift voor Nederlandsch Indië, dl. XI, blz. 332 , noot. 
zegt dan ook van de bewoners van de benedenlanden van Palembang, dat zij, natuurlijk onbewust, de goede uitwerking van het jodium tegen de kropgezwellen kennen, waarom zij aan de lijders zeewater te drinken geven of hen naar de bovenlanden zenden, "waar eenige jodium-houdende bronnen eene zekere vermaardheid tegen deze ziekte verkregen hebben" 232. Intusschen is het uit een scheikundig onderzoek gebleken, dat het water van de zooeven bedoelde minerale bronnen in Semendo geen jodium bevat, doch dat het voornaamste bestanddeel daarvan chloornatrium is, namelijk 0.79308 van de 1.0482 pCt. vaste stoffen 233. Evenmin is er jodium in het water van de Ajer-Poetih, terwijl slechts sporen er van zijn aangetroffen in de heete bronnen, in de nabijheid van deze rivier gelegen 234. Wat het water van de minerale brounen in het gebied van de Sipaoek-rivier betreft, heeft een scheikundig onderzoek aangetoond, dat het, evensls het water van Semendo, eene groote hoeveelheid chloornatrium bevat, namelijk 5.34024 van de 7.33244 pCt. daarin aanwezige vaste stoffen. Daarentegen is het gehalte aan jodium, onder den vorm van jodmagnesium, uiterst gering, namelijk 0.00808 pCt. 235. Dit geringe jodiumgehalte maakt de gegrondheid van het volksgevoelen minstens genomen zeer twijfelachtig, dat het water eene verzwakkende werking op het voorttelingsvermogen zou uitoefenen, waarom de strumalijders het liever uit- dan inwendig gebruiken.

Andere geneesmiddelen tegen de struma schijnen bij de inlanders

232 Lindman, Geneeskundig topographische schets van de hoofdplaats Palembang, Geneeskundig Tijdschrift voor Nederlandsch Indië, dl. IV, blz. 775.

233 Maier, Scheikundig onderzoek van eenige minerale bronnen, afkomstig uit het landschap Semendo, Natuurkundig Tijdschrift voor Nederl. Indië, dl. XXX, blz. 51. - Overigens bevat het water nog: koolzure kalk, koolzure magnesia, chloorkalium, chloorcalcium, chloormagnesium, zwavelzure kalk en kiezelaarde.

234 Natuurkundig Tijdschrift voor Nederl. Indië, dl. XXIII, blz. 378 vlg. en 382 vlg. - Het water van de heete bron bevat verder: koolzure soda, koolzure magnesia, koolzure kalk, zwavelzure kali, zwavelzure soda, chloornatrium, chloormagnesium, aluinaarde en kiezelaarde. In het water van de Ajer-Poetih komt onder anderen voor: koolzure soda, koolzure kalk, koolzure magnesia, zwavelnatrium, en zeer geringe hoeveelheden zwavelzure kali, chloornatrium, chloormagnesium, kiezelaarde en aluinaarde.

235 Bleekrode, Scheikundig onderzoek van bronwater van Sepauk, Geneeskundig Tijdschrift voor Nederl. Indië, dl. XI, blz. 332 vlg. Eene latere analyse gaf slechts 5.82631 pCt. vaste stoffen, waaronder 0.00494 jodmagnesium (Natuurkundig Tijdschrift voor Nederl. Indië, dl. XXVII, blz. 443 vlg.) - Overigens bevat het water chloorkalium, chloormagnesium, chloorcalcium, zwavelzure kalk, koolzuur ijzeroxydule, koolzure kalk, koolzure magnesis, kiezelzuur en aluinaarde. 
niet bekerid te zijn. Alleen deelt de Heer Poensen ons mede, dat men in Kediri de kroppen, blijkbaar ter verkoeling en verzachting, wel eens met kalkwater of met wrdak, rijstepoeder met water aargemaakt, besmeert, terwijl, volgens den Heer Neeb, door sommigen uitwendig het sap van de ketjubung-putih, de datura alba, wordt aangewend, hetwelk bedwelmende en pijnstillende eigenschappen bezit, en daarom door den inlander vaak bij zweren en gezwellen gebruikt wordt 236.

IV.

In streken met endemische struma worden dikwijls gevallen van cretinisme waargenomen. "Ueberall", merkt Virchow op, "wo der an territoriale Bedingungen gebundene Cretinismus vorkommt, ist auch Kropf endemisch.... und man kann nicht umhin, beide aus gleichartigen Einflüssen abzuleiten, den Kropf als das Resultat der geringeren, den Cretinismus als das Ergebniss der stärkeren Einwrikung der schädlichen Potenz anzusehen" 237), Sommigen gaan verder, en nemen aan, dat er een genetisch verband tusschen struma en cretinisme bestaat. Men heeft namelijk waargenomen, dat in vele gevallen cretins van strumueuze ouders afstammen. "Fodéré", lezen "wij bij Hirsch, "hat diesen causalen Zusammenhang zwischen Kropf der Eltern und cretinistischer Erkrankung der Nachkommerschaft zuerst erkaunt und zahlreiche weitere Bestätigungen hat die Thatsache .... in den Erfahrungen gefunden, welche Roulin, Tourdes, Grange, Morel, Mc Clelland, Garrigou, Köstl, die französische Commission u. v. a. darüber gemacht haben und welche Fabre in den Worten ausdrückt: le goître est le père du crétinisme" 238. Volgens eenige onderzoekers zouden twee generaties van lijders aan kropgezwellen voldoende zijn, om in de derde generatie cretinisme te doen ontstaan.

Neemt men aan dat struma een vroeger stadium van cretinisme is, dan laat zich daaruit vanzelf het feit verklaren, dat, waar dit laatste voorkomt, ook de eerste aanwezig is, het omgekeerde echter niet altijd het geval behoeft te zijn. Dit zien wij ook in den Indischen Archipel.

236 Filet, Plantkundig woordenboek voor Nederlandsch Indië, blz. 188, No 4959 (van den tweeden druk).

237 Zie: Hirsch, Handbuch der historisch-geographischen Pathologie, dl. II , blz. 138.

238 Hirsch, O. e., blz. 139. 
Bijna nergens komt cretinisme hier voor. De meeste berichtgevers over struma maken er althans geen gewag van. Integendeel verklaren enkele uitdrukkelijk, geen cretins te hebben ontmoet. "Cretinisme komt onder de bergbewoners (van Bali) niet voor", merkt Dr. Jacobs op 239. Van de Orang-Bukit zegt Grabowsky: "Cretinismus habe ich nicht bei ihnen beobachtet” ${ }^{240}$. Ook de Heeren Neeb en Poensen deelen mij mede, dat cretinisme in het strumagebied van Kediri niet wordt aangetroffen. Slechts op een tweetal berichten hebben wij te wijzen omtrent het voorkomen van deze kwaal in den Indischen Archipel. Waar namelijk Dr. Hagen van de endemische struma in de bovenlanden van Deli en Serdang gewaagt, spreekt hij ook van "kretinartige Erscheinungen", die zich daar voordoen 241 . In een later reisverhaal wordt door hem nogmaals van deze kwaal melding gemaakt. "Wir erhielten hier (in een dorp waar het reisgezelschap van Dr. Hagen overnachtte) Hühner und einen sehr guten Palmwein, welcher herrlich schmeckte. Leider ward er jedoch durch den Sohn des Pangulu (Häuptlings) kredenzt, welcher, ein vollständiger Cretin, wie sie in diesen Berggegenden nicht gerade sehr selten vorzukommen pflegen, durch seine scheussliche Missgestalt mir fast allen Appetit nach diesem herrlichen Getrink benommen hätte" 242. Het andere bericht, waarop ik hier de aandacht wensch te vestigen, is van den Heer Van Hasselt. "Gebrekkigen", schrijpt hij van zijn verblijf te Soeka-Radja in Rawas, "nontmoet men hier weinig, wanneer men althans een enkelen eenoogige niet mederekent en een paar idioten, die in bijna elke doesoen gevonden worden. Meestal zijn deze ongelukkigen ook lichamelijk misvormd; wij hadden er reeds dien morgen te Tandjoeng-Agoeng een gezien met een buitengewoon groot hoofd, een mismaakten mond, wijj uit. eenstaande beenen en lange magere armen" 243. Hier hebben wij dus ook, in een gebied met endemische struma, personen die blijkbasr cretins zijn.

239 Jacobs, Eenigen tijd onder de Baliërs, blz. $20 \mathrm{vlg}$.

240 Zie noot 74 hierboven.

241 Hagen, Eine Reise nach dem Tobah-See in Zentralsumatra, Petermanna Mitteilungen, dl. XXIX, blz. 44.

242 Hagen, Rapport über eine im December 1883 unternommene wissensohaftliche Reise an den Toba-See, Tijdschrift v. Ind. T. L. en Vk, dl, XXXI, blz. 331-332. 243 Reizen in Midden-Sumatra door de leden der Sumatra-expeditie, dl. II, blz. 103. 